Manajemen Pemasaran.

Syariah

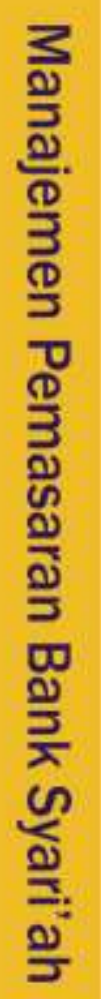

Manajemen
Pemasaran Bank Syariah

FITRI NUR LATIFAH M. RUSLIANOR MAIKA 


\section{BUKU AJAR \\ MANAJEMEN PEMASARAN BANK SYARIAH}

Oleh

Fitri Nur Latifah, S.E., M.E.Sy.

M. Ruslianor Maika, S.Hut., M.A.B.

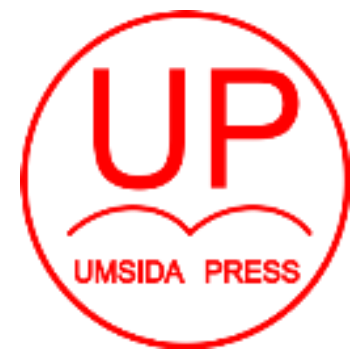

Diterbitkan oleh UMSIDA PRESS

Jl. Mojopahit 666 B Sidoarjo

ISBN: 978-623-7578-29-1

Copyright@2019

Authors

All rights reserved 


\section{BUKU AJAR \\ MANAJEMEN PEMASARAN BANK \\ SYARIAH}

\section{Penulis :}

Fitri Nur Latifah, S.E.,M.E.Sy.

M. Ruslianor Maika, S.Hut., M.A.B.

\section{ISBN :}

\section{Editor :}

Septi Budi Sartika, M.Pd

M. Tanzil Multazam, S.H., M.Kn.

\section{Copy Editor :}

Fika Megawati, S.Pd., M.Pd.

Design Sampul dan Tata Letak :

Mochamad Nashrullah, S.Pd

Penerbit :

UMSIDA Press

\section{Redaksi :}

Universitas Muhammadiyah Sidoarjo

J1. Mojopahit No 666B

Sidoarjo, Jawa TImur

Cetakan pertama,

(C) Hak cipta dilindungi undang-undang

Dilarang memperbanyak karya tulis ini dengan suatu apapun tanpa ijin tertulis dari penerbit. 


\section{KATA PENGANTAR}

Assalamualaikum Wr.Wb.

Alhamdulillah, Puji syukur penulis panjatkan kepada Alloh Subhanahu Wata'ala atas segala nikmat, rahmat dan karunianya sehingga penulis mampu menyusun buku yang sederhana sebagai kontribusi dalam upaya terus mengembangkan Ekonomi Islam khususnya bidang manajemen pemasaran bank syariah di tanah air tercinta ini.

Sebagaimana kita ketahui bersama perkembangan Banks Syariah maupun lembaga keuangan syariah di Indonesia dari tahun ke tahun senantiasa menunjukkan peningkatan.

Sayangnya buku ajar yang terkait dengan mata kuliah pendukung hal tersebut belum banyak tersedia. Melihat kebutuhan yang mendesak tersebut, penulis mencoba untuk menyusun sebuah buku yang kami yakin dapat memberikan pengetahuan pada mahasiswa.

Akhirnya, penulis mengucapkan terima kasih atas segala bantuan yang telah diberikan oleh berbagai pihak, terutama pada Universitas Muhammdiyah Sidoarjo sehingga dapat terlaksananya penulisan buku ini. Penulis menyadari bahwa buku ini masih jauh dari sempurna. Oleh karena itu, segala kritik, tanggapan maupun saran yang bersifat membangun dari segenap pembaca sangat diharapkan, demi perbaikan di masa-masa mendatang.

Sidoarjo, Oktober 2018

Fitri Nur Latifah

M. Ruslianor Maika 


\section{DAFTAR ISI}

Cover

Identitas Buku

Kata Pengantar

Daftar isi

Bab I : Pemasaran Perspektif Konvensiona

A. Pengertian Pemasaran ........................................ 7

B. Konsep Pemasaran ....................................... 12

C. Pangsa Pasar dan Bauran Pemasaran _............. 25

D. Teori Merek ................................................. 39

E. Segmentasi Pasar _........................................ 52

Bab II : Pemasaran Prespektif Syariah ............................... 59

A. Definisi Pemasaran Syariah _........................ 59

B. Pemasaran dalam Prespektif Syariah .................. 71

C. Karakter Pemasaran Syariah _.................... 73

D. Etika dalam Pemasaran Syariah......................... 77

E. Perbandingan Pemasaran Syarian dan Pemasaran Konvensional.................................................. 98

Bab III : Implementasi Pemasaran Syariah_..........................128

A. Empat Aksioma Sistem Ekonomi Islam ..............128

B. Etika Berbisnis .......................................... 137

C. Implementasi Bauran Pemasaran 147

D. Strategi Pemasaran Bank Syariah _................... 162

E. Kualitas pelayanan ...................................... 164

Bab IV : Gambaran Umum Perbankan Syariah ..................... 168

A. Pengertian Bank Syariah................................168

B. Peranan Bank Syariah Bagi Perekonomian .........171

C. Landasan Hukum Bank Syariah.........................172

Daftar Pustaka 


\section{BAB I \\ Pemasaran Prespektif Konvensional}

Pemasaran adalah salah satu kegiatan pokok yang perlu dilakukan oleh perusahaan baik itu perusahaan barang atau jasa dalam upaya untuk mempertahankan kelangsungan hidup usahanya. Hal tersebut disebabkan karena pemasaran merupakan salah satu kegiatan perusahaan, di mana secara langsung berhubungan dengan konsumen. Maka kegiatan pemasaran dapat diartikan sebagai kegiatan manusia yang berlangsung dalam kaitannya dengan pasar. Kotler (2001) mengemukakan definisi pemasaran berarti bekerja dengan pasar sasaran untuk mewujudkan pertukaran yang potensial dengan maksud memuaskan kebutuhan dan keinginan manusia. Sehingga dapat dikatakan bahwa keberhasilan pemasaran merupakan kunci kesuksesan dari suatu perusahaan.

\section{A. Pengertian Pemasaran}

Pemasaran dalam perspektif konvensional pengertian pemasaran memiliki peran pokok dalam peta bisnis suatu perusahaan dan berkontribusi terhadap strategi produk. Perusahaan baik berskala nasional maupun internasional membutuhkan seorang marketer handal yang memasarkan produk atau jasa.kesuksesan suatu produk diterima oleh target pasar tidak hanya ditentukan oleh murahnya harga atau kualitas yang ditawarkan, tetapi ditentukan juga oleh strategi pemasaran yang dilakukan. 
Pemasaran sebagai salah satu aspek yang sangat penting di dunia usaha pada kondisi usaha seperti sekarang ini pemasaran menjadi pendorong untuk meningkatkan penjualan sehingga tujuan perusahaan dapat tercapai. Wawasan tentang masalah menjadi penting bagi perusahaan pada saat dihadapkan pada beberapa permasalahan, seperti menurunnya pendapatan perusahaan yang disebabkan oleh turunnya daya beli konsumen terhadap suatu produk baik barang maupun jasa sehingga mengakibatkan lambatnya perusahaan untuk berkembang.

Perkembangan dunia usaha yang dinamis dan penuh persaingan menurut perusahaan menuntut untuk melakukan perubahan orientasi terhadap cara mereka melayani konsumennya menangani pesaing dan mengeluarkan produk.

Persaingan yang ketat menuntut perusahaan untuk semakin inovatif dalam mengeluarkan produk yang sekiranya disukai konsumen. Tanpa inovasi produk suatu perusahaan dapat tenggelam dalam persaingan dengan produk-produk lain yang semakin memenuhi pasar. Di lain pihak konsumen juga semakin kritis terhadap apa yang mereka terima dan harapkan dari suatu produk. Jika ternyata tidak sesuai dengan harapan pelanggan, perusahaan tidak hanya akan kehilangan kepercayaan pelanggan tetapi juga berpotensi atau kehilangan pelanggan potensial. Pelanggan yang puas akan terus melakukan pembelian namun pelangganan yang tidak puas akan menghentikan pembelian produk bersangkutan ada kemungkinan akan menyebutkan atau menyebarkan berita tersebut melalui orang lain dalam (Setiadi 2003). 
Konsep pemasaran konvensional modern yang diperhatikan yang diperhatikan adalah bagaimana agar produk baru dikenal oleh pasar dan diterima demikian pula produk yang sudah ada dengan mementingkan keuntungan produk saja. Para marketer dituntut untuk berfikir mencari cara dalam menarik minat dengan memperhatikan target pasar dengan meningkatkan kreativitas, baik dengan menggunakan gambar ataupun pengolahan kata lalu memberikan pengaruh terhadap semua ideide agar sasaran pasar tertarik untuk mengambil keputusan untuk membeli.

Pemasaran tidak terbatas dalam bisnis saja kapan saja usaha meyakinkan seseorang untuk membuat sesuatu seperti donor darah, menghemat listrik, memilih pasangan itu telah terlihat dalam pemasaran. Jadi, pemasaran mempunyai makna kemasyarakatan yang luas. Sebenarnya, pada saat ini pandangan kemasyarakatan memang lebih sesuai untuk pemasaran. Kegiatan masyarakat bisnis yang modern secara umum merupakan akibat dari pandangan masyarakat terhadap pemasaran (Abdullah dan Tantri 2014).

Kesuksesan finansial sering tergantung pada kemampuan pemasaran, financial, operasi, akuntansi dan fungsi bisnis lainnya tidak akan berarti jika tidak ada cukup permintaan akan produk dan jasa sehingga perusahaan bisa menghasilkan keuntungan harus ada pendapatan agar laba didapat banyak perusahaan kini telah menciptakan posisi marketing officer atau CMO untuk meletakkan pemasaran pada posisi yang lebih setara dengan eksekutif tingkat $\mathrm{C}$ lainnya seperti chief executive officer atau CEO atau si financial officer atau CFO (kotler dan Keller 2009). 
Pemasaran menghasilkan pendapatan yang dikelola oleh orang-orang keuangan dan kemudian didayagunakan oleh orangorang diproduksi untuk mencipta produk atau jasa titik tantangan bagi pemasaran adalah menghasilkan pendapatan dengan memenuhi keinginan para konsumen pada tingkat laba tertentu tanpa melupakan tanggung jawab sosial (Abdullah dan Tantri 2014).

Banyak ahli yang telah memberikan definisi pemasaran, definisi yang diberikan sering berbeda antara satu dengan yang lain disebabkan adanya perbedaan sudut pandang dan melinjo pemasaran titik aktivitas pertukaran merupakan hal sentral dari kegiatan pemasaran. Pertukaran merupakan kegiatan pemasaran dimana seseorang berusaha menawarkan sejumlah barang atau jasa dengan sejumlah nilai ke berbagai macam kelompok sosial untuk memenuhi kebutuhannya. Pemasaran sebagai kegiatan manusia diarahkan untuk memuaskan dan kebutuhan melalui proses pertukaran.

Menurut gronroos (1987) pemasaran bertujuan untuk menjalin mengembangkan dan memperkenalkan hubungan dengan pelanggan untuk jangka panjang sedemikian rupa sehingga tujuan masing-masing pihak dapat dipenuhi. Hal ini dilakukan melalui proses pertukaran dan saling memenuhi janji.

Gronroos (1993) mendefinisikan pemasaran adalah mengembangkan pembangunan pertahankan dan meningkatkan koordinasi dengan para pelanggan dan mitra lainnya dengan mendapatkan sedemikian rupa sehingga tujuan masing-masing pihak tercapai. Hari ini diwujudkan melalui pertukaran dan memenuhi janji yang saling menguntungkan. 
Miller dan Layton (2000), menjelaskan pemasaran merupakan suatu sistem aktivitas bisnis adalah untuk merencanakan rumah menetapkan harga memproduksi dan mendistribusikan produk jasa dan gagasan yang mampu memuaskan keinginan pasar sasaran dalam rangka mencapai tujuan organisasional.

Doyle (2000) memberikan definisi tentang pemasaran yang merupakan proses manajemen yang berupaya memaksimalkan laba bagi pemegang saham dengan jalan menjalin relasi dengan pelanggan utama (value customer) dan menciptakan keunggulan kompetitif American Marketing Association dalam (AMA) pada tahun 2004 menjelaskan, pemasaran adalah fungsi organisasi dan serangkaian proses penciptaan mengkomunikasikan dan menyampaikan nilai bagi para pelanggan, serta mengelola relasi pelanggan sedemikian rupa sehingga memberikan manfaat bagi organisasi dan para stakeholders nya.

Pada 2007, mendefinisikan pemasaran sebagai aktivitas, serangkaian institusi dan proses menciptakan komunikasikan menyampaikan dan mempertukarkan tawaran (offering) yang bernilai bagi pelanggan, mitra dan masyarakat umum.

Menurut Hunt (1976), domain konseptual pemasaran mencakup beberapa aspek seperti mikro marketing dan makro marketing, positive theory of marketing dan normative theory of marketing, serta profit marketing dan nonprofit marketing.

Evolusi definisi pemasaran meliputi 3 tahapan pokok selama satu abad terakhir (Lusch,2007): "to market", "market(ing) to", dan "market(ing) with". "To market" mencerminkan misi utama pemasaran untuk menghadirkan atau membawa produk 
konsumen (pasar). ,"Market(ing) to" bermakna misi utama pemasaran untuk mengidentifikasi pelanggan dan memasarkan produk kepada mereka sedangkan marketing berarti bahwa misi utama Pemasaran adalah berkolaborasi dengan pelanggan untuk bersama-sama menciptakan nilai (co creation) dalam (tjiptono dan Chandra, 2012).

Berdasarkan penjelasan diatas dapat disimpulkan Pemasaran adalah salah satu proses kegiatan dalam perekonomian yang membantu dalam menciptakan nilai ekonomi. Nilai ekonomi itu sendiri menentukan harga barang dan jasa. Faktor penting dalam menciptakan nilai tersebut adalah produksi pemasaran konsumsi dan mengomersialisasikan relasi dengan konsumen untuk jangka panjang. Pemasaran menjadi penghubung antara kegiatan produksi dan konsumsi. Definisi pemasaran ini berdasarkan pada konsep inti yang meliputi kebutuhan (needs) dan keinginan (wants) dan permintaan (demands)

\section{B. Konsep Pemasaran}

Konsep pemasaran (marketing concept) beranggapan bahwa untuk mencapai tujuan organisasi terdiri dari penentuan kebutuhan, keinginan pasar sasaran, serta memberikan kepuasan kepada konsumen yang diharapkan secara lebih efektif dan efisien dibandingkan para pesaing. Tjiptono dan Chandra (2012) menjelaskan lebih perinci, nilai pelanggan (customer value) adalah rasio antara apa yang diperoleh pelanggan dan apa yang ia berikan. Jadi, rumusan nilai pelanggan adalah: 
NILAI PELANGGAN = [ manfaat - biaya $]=[$ manfaat fungsional + manfaat emosional] - [biaya moneter - biaya waktu + biaya energi + biaya psikis]

Empat pilar dalam konsep pemasaran terdiri dari pasar sasaran (target market), kebutuhan konsumen, pemasaran yang terintegrasi (intergrated marketing), dan profitabilitas. Keberhasilan pemasaran sangat ditentukan oleh kemampuan organisasi dalam membedakan lima jenis kebutuhan, terdiri dari:

1. Stated needs atau kebutuhan yang dijelaskan (contohnya, konsumen membutuhkan mobil yang tidak mahal);

2. Real needs atau kebutuhan yang sebenarnya (contohnya, konsumen membutuhkan mobil yang biaya operasionalnya (bukan harga awalnya) rendah;

3. Unstated needs atau kebutuhan yang tidak dijelaskan (contohnya, konsumen berharap pihak dealer mobil tersebut memberikan pelayanan yang baik);

4. Delight needs atau kebutuhan kesenangan (contohnya, konsumen mengharapkan agar dealer mobil tersebut juga menambahkan head unit lengkap dengan sistem navigasi yang terkini;

5. Secret needs atau kebutuhan rahasia (contohnya, konsumen ingin dirinya dipandang sebagai konsumen yang cerdas dengan memilih produk oleh temantemannya.

Theodore Levitt dari Harvard menjelaskan perbedaan antara konsep penjualan dan konsep pemasaran: 
Penjualan berfokus pada kebutuhan penjual; pemasaran berfokus pada kebutuhan pembeli. Penjualan didasari oleh kebutuhan penjual untuk mengubah produknya menjadi uang; pemasaran didasari oleh gagasan untuk memuaskan kebutuhan pelanggan melalui produk dan hal-hal yang berhubungan dengan menciptakan, menghantarkan, dan akhirnya mengonsumsinya. Tujuan akhir konsep pemasaran ini adalah membantu tercapainya tujuan dari organisasi. Tujuan utama dari organisasi bisnis adalah laba, sedangkan tujuan organisasi nirlaba dan organisasi sosial adalah memperoleh dana untuk aktivitas sosial ataupun aktivitas pelayanan publik.

Tujuan pemasaran menurut Drucker adalah untuk mengetahui dan memahami pelanggan dengan baik sehingga produk atau jasa sesuai dan dengan sendirinya terjadilah penjualan. Idealnya, pemasaran harus menghasilkan pelanggan yang siap untuk membeli. Caranya adalah dengan membuat produk atau jasa tersedia.

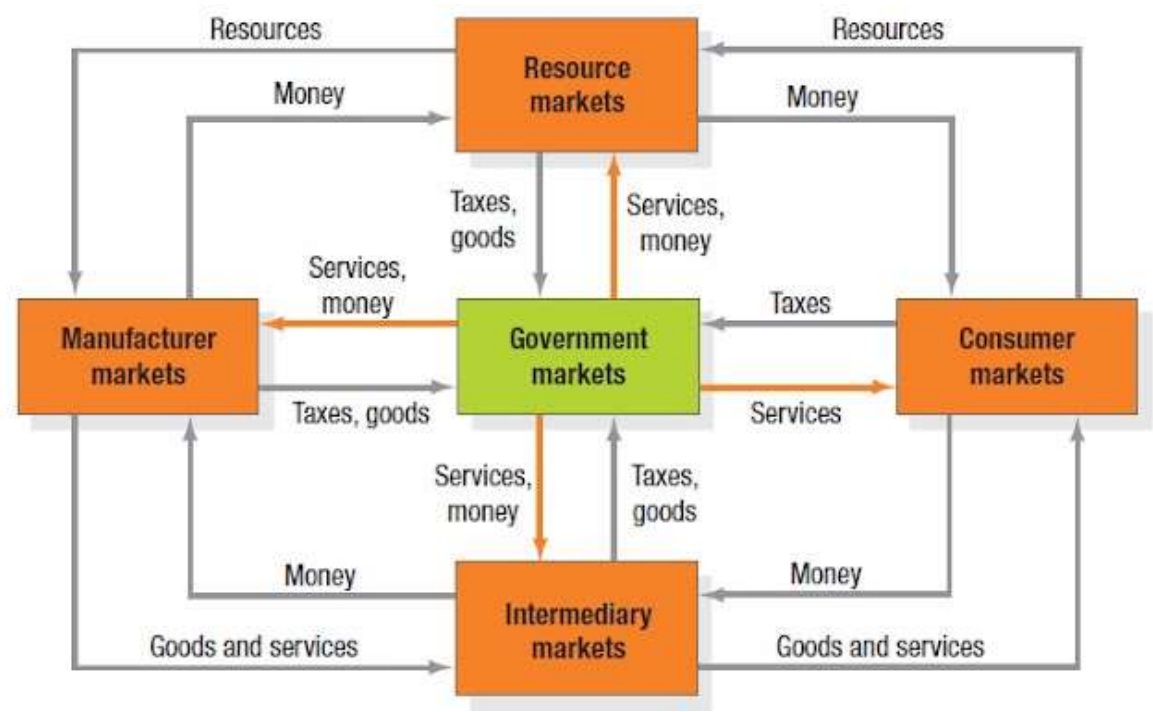


Untuk memahami fungsi pemasaran, kita perlu memahami serangkaian konsep inti dalam pemasaran. Beberapa konsep inti dalam pemasaran yaitu:

1. Kebutuhan, keingina, dan permintaan.

Kebutuhan adalah syarat hidup dasar manusia. Kebutuhan akan menjadi keinginan ketika diarahkan ke objek tertentu. Permintaan adalah keinginan akan produk-produk tertentu yang didukung oleh kemampuan untuk membayar.

2. Pasar sasaran, positioning, dan segmentasi.

Target dari barang atau jasa yang akan dihasilkan harus jelas sasarannya, terkait dengan keputusan penentuan pasar memiliki beberapa tahap analisis:

a. Analisis peluang, yaitu tidak semua orang mampu melihat peluang, bahkan bisnis yang potensial adakalanya dikatakan sama sekali tidak prospek. Umpamanya, analisis dari dua orang yang berbeda bisa memberi hasil yang berbeda.

b. Analisis lingkungan usaha, yaitu analisis terhadap faktor-faktor yang berpengaruh di dalam pasar, misalnya regulasi yang berlaku, sikap pemerintah terhadap usaha tersebut, oknum (pebisnis), aspirasi masyarakat sekitar, pesaing, teknologi, budaya setempat dan sebagainya.

c. Seleksi target market (pasar sasaran). Proses seleksi ini disebut juga segmentasi pasar. Mulanya pasar disegmentasikan menurut demografi, usia, 
gender, lokasi, pendapatan, pekerjaan, pendidikan, generasi dan sebagainya.

Lebih lanjut segmentasi pasar dapat dijelaskan sebagai berikut:

- Segmentasi geografik, yaitu membagi pasar menjadi beberapa unit secara geografik seperti negara, regional, negara bagian, kota atau kompleks perumahan.

- Segmentasi demografik, yaitu membagi pasar menjadi kelompok berdasarkan pada variabel seperti umur, jenis kelamin, ukuran keluarga, daur kehidupan keluarga, pendapatan, pekerjaan, pendidikan, agama, ras, dan kebangsaan.

- Segmentasi psikografis, yaitu mengelompokkan konsumen atau pembeli menjadi bagian pasar menurut variabel-variabel pola atau gaya hidup (life style) dan kepribadian (personality).

- Segmentasi tingkah laku, yaitu mengelompokkan pembeli pada pengetahuan, sikap, penggunaan atau reaksi mereka terhadap suatu produk.

\section{Penawaran dan merek.}

Penawaran pada hakikatnya memberikan penjelasan terkait dengan produk atau jasa yang dijual. Pada hakikatnya, merek dapat menjadi dasar konsumen dalam memutuskan untuk membeli barang atau jasa. 


\section{Nilai dan kepuasan.}

Nilai mencerminkan sejumlah manfaat baik yang berwujud maupun tidak berwujud, dan biaya yang dipersepsikan oleh pelanggan. Kepuasan mencerminkan penilaian seseorang tentang kinerja produk anggapannya (atau hasil) dalam kaitannya dengan ekspektasi.

5. Saluran pemasaran.

Untuk mencapai pasar sasaran, pemasar menggunakan tiga jenis saluran pemasaran, yaitu saluran komunikasi, saluran distribusi, dan saluran layanan.

6. Rantai pasokan (supply chain).

Rantai pasokan adalah saluran yang lebih panjang yang membentang dari bahan mentah hingga komponen sampai produk akhir dihantarkan ke pembeli akhir.

7. Persaingan.

Persaingan mencakup semua penawaran dan produk substitusi yang ditawarkan oleh pesaing baik yang aktual maupun yang potensial, yang mungkin dipertimbangkan oleh seorang pembeli.

8. Lingkungan pemasaran.

Lingkungan pemasaran terdiri dari lingkungan tugas (perusahaan, pemasok, distributor, dealer, dan pelanggan sasaran) dan lingkungan demografis (lingkungan ekonomi, fisik, teknologi, politik-hukum, dan sosial budaya). 
Pasar tidak lagi seperti dulu, pemasar harus memperhatikan dan merespons sejumlah perkembangan signifikan sebagai realitas pemasaran baru diantaranya:

1. Kekuatan kemsyarakatan utama, terdiri dari teknologi informasi jaringan, globalisasi, deregulasi, privatisasi, persaingan yang meningkat, konvergensi industri, resistensi konsumen, transformasi eceran, dan disintermediasi.

2. Kemampuan baru konsumen, yang terdiri daripeningkatan yang berarti dalam hal daya beli, ragam barang dan jasa yang lebih banyak, sejumlah besar informasi hampir tentang apa saja, kemudahan yang lebih besar dalam memesan dan menerima pesanan, kemampuan untuk membandingkan catatan tentang produk dan jasa serta suara yang lebih kuat untuk mempengaruhi teman sepergaulan dan pendapat umum.

3. Kemampuan baru perusahaanb, di antaranya pemasar dapat menggunakan internet sebagai saluran informasi, peneliti dapat mengumpulkan informasi lebih lengkap, komunikasi internal lebih cepat melalui internet, komunikasi eksternal dengan pelanggan bisa lebih cepat, pemasaran target dan komunikasi dua arah menjadi lebih mudah, pemasar bisa mengirimkan iklan langsung, mobile marketing dan perusahaan dapat memproduksi barang yang dideferensiasikan, manajer dapat memperbaiki sistem korporat bisa melakukan penghematan dan perekrutan bisa dilakukan secara online. 
Dengan adanya realitas pemasaran baru diatas, para pemasar semakin mampu beroperasi secara konsisten dengan suatu konsep pemasaran holistik. Beberapa gagasan pemasaran awal di antaranya adalah:

1. Konsep produksi: konsumen menyukai produk yang murah da tersedia.

2. Konsep produk: konsumen menyukai produk yang menawarkan mutu yang paling baik atau coraj yang inovatif.

3. Konsep penjualan: konsumen akan membeli produk hanya jika perusahaan agresif menjual dan berpromosi.

4. Konsep pemasaran: berpusat pada keinginan target pasar dan mengirimkan nilai lebih baik daripada pesaing.

5. Konsep pemasaran hollstik: berdasarkan kepada pembentukan, perencanaan, implementasi program, proses, dan aktivitas pemasaran.

Pemasaran hubungan (relationship marketing) bertujuan untuk membangun hubungan jangka panjang yang saling memuaskan dengan konstituen kunci guna mendapatkan dan mempertahankan bisnis. Empat konstituen kunci untuk pemasaran hubungan adalah pelanggan, pegawai, mitra pemasaran dan anggota masyarakat finansial. Salah satu tujuan pemasaran hubungan adalah menempatkan penekanan yang lebih besar pada kegiatan mempertahankan pelanggan karena 
menarik pelanggan baru mungkin memerlukan biaya lima kali lebih besar daripada mempertahankan pelanggan.

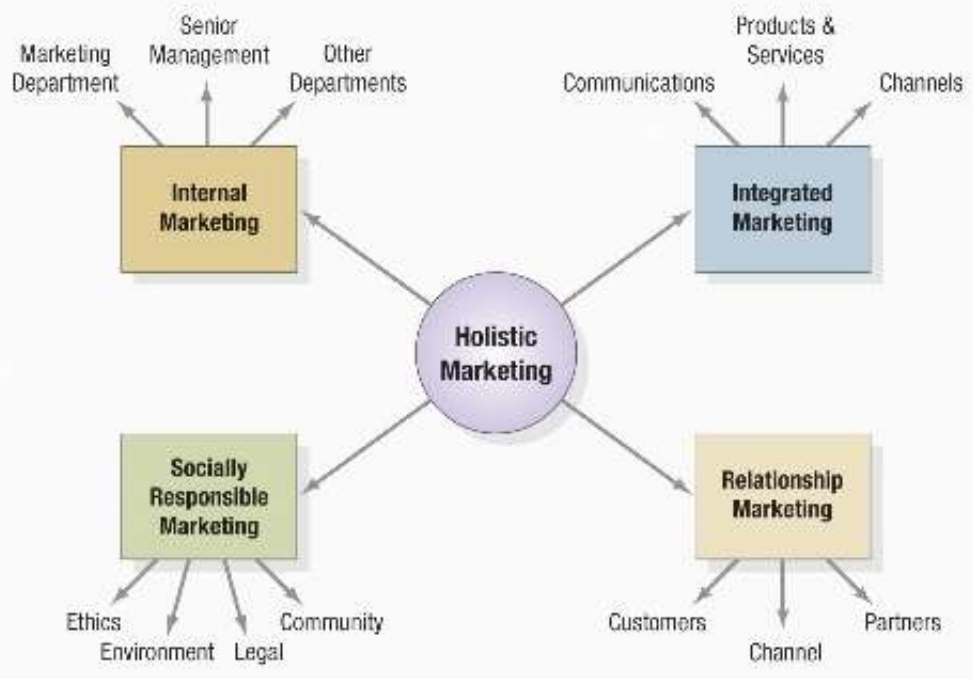

1. Kebutuhan, Keinginan, dan Permintaan

Kebutuhan adalah syarat dasar manusia dalam kehidupan ini. Setiap manusia membutuhkan makanan, air, udara, pakaian, dan tempat tinggal untuk bertahan hidup. Di luar kebutuhan akan makanan, air, udara, pakaian, dan tempat tinggal, manusia juga mempunyai keinginan yang kuat untuk rekreasi, hiburan, pendidikan, ataupun jasa lainnya. Setiap manusia mempunyai pilihan akan macam dan merek tertentu dari barang dan jasa yang mereka butuhkan dan inginkan. 
Permintaan adalah keinginan akan produk-produk tertentu yang didukung dengan kemampuan dan kesediaan untuk membayarnya. Keinginan dapat berubah menjadi permintaan apabila didorong oleh daya beli yang tinggi. Banyak orang ingin memiliki mobil Ferrari, tetapi hanya sedikit yang mampu dan sedia untuk membelinya. Selain harus mengukur berapa banyak orang yang benar-benar mampu dan sedia untuk membeli produknya.

Perbedaan ini dapat menjelaskan akan kritik dari pengkritik pemasaran bahwa "pemasar menciptakan kebutuhan" atau "pemasar membuat seseorang membeli barang-barang yang tidak mereka inginkan". Pemasar tidak menciptakan kebutuhan; kebutuhan sudah ada sebelum itu. Pemasar, seperti juga contoh lain di masyaraka, memengaruhi keinginan. Pemasar mungkin memberikan ide bahwa sebuah Ferrari dapat memenuhi dan memberikan kepuasan seseorang akan status sosial itu.

Menurut Swastha dan Handoko (2000) menyatakan bahwa terdapat falsafah bisnis yang menyatakan bahwa pemuasan kebutuhan konsumen merupakan syarat ekonomi dan sosial bagi kelangsungan hidup perusahaan. Konsep pemasaran bertujuan memberikan kepuasan terhadap keinginan dan kebutuhan konsumen atau berorientasi pada konsumen (consumer oriented), hal ini berbeda dengan pandangan yang terdahulu bahwa pemasaran berorientasi kepada produk, penjualan dan keungan perusahaan. 
Falsafah pemasaran mengalami perubahan dari orientasi internal menuju orientasi eksternal. Maksudnya, pemasaran beralih dari semula "berusaha menjual apa saja yang bisa saya produksi" menjadi "berusaha memproduksi baik barang maupun jasa yang bisa dijual karena konsumen menginginkan dan membutuhkan produk itu".

\section{Konsep Produksi}

Konsep produksi adalah salah satu konsep tertua dalam bisnis. Konsep ini berorientasi pada produksi dengan mengarahkan segenap upaya untuk mencapai efisiensi produk tinggi dan distribusi yang luas. Konsep ini menyatakan bahwa konsumen lebih menyukai produk yang tersedia dalam jumlah banyak dan tidak mahal.

Tjiptono dan Chandra (2012) menjelaskan konsep produksi (production concept) berkeryakinan bahwa konsumen akan menyukai produk-produk yang tersedia di mana-mana dan harganya murah. Penganut konsep ini akan berkonsentrasi pada upaya menciptakan efisiensi produksi, biaya rendah, dan distribusi massal.

Fokus utama dari konsep produksi ini ditekankan pada distribusi dan harga. Negara-negara berkembang seperti Republik Rakyat Cina, di mana pabrik teknologi seperti Lenovo, Huawei, dan pabrik alat-alat rumah tangga seperti Hailer dapat menghasilkan keuntungan yang besar dan murah untuk membanjiri pasar dengan produk-produk murahnya. 
Konsep produk (product concept) mengatakan bahwa konsumen akan menyukai produk yang menawarkan mutu, kualitas fitur-fitur yang inovatif, dan performa yang terbaik. Konsep ini berfokus pada usaha penciptaan suatu produk dan penyempurnaan dari kualitas tersebut. Penganut konsep ini konsentrasi pada aspek produk. Pemasaran dengan konsep ini sering dijumpai dalam pemasaran produk karya seni dan elektronik.

Konsep penjualan (selling concept) beranggapan bahwa konsumen tidak akan tertarik tuntuk membeli produk dalam jumlah banyak, jika mereka tidak diyakinkan bahkan jika perlu harus dibujuk. Konsep ini banyak ditemukan pada penjualan unsoughts goodsi (barang-barang yang tidak dicari) seperti ensiklopedia, peti mati, dan asuransi.

Beberapa perusahaan juga mempraktikkan konsep penjualan ketika mangalami kelebihan kapasitas/overcapacityi (penawaran jauh melampaui permintaan) dengan tujuan menjual apa yang mereka produksi.

\section{Konsep Pemasaran Sosial}

Konsep pemasaran sosial (societal marketing concept) beranggapan bahwa tugas organisasi adalah menentukan kebutuhan, keinginan dan kepentingan pasar sasaran serta memberikan kepuasan yang diharapkan dengan cara yang lebih efektif dan efisien daripada para pesaing dengan tetap melestarikan atau meningkatkan kesejahteraan konsumen dan masyarakat. Aspek sosial dan etika dalam praktik pemasaran 
sangat ditekankan dalam konsep ini, maka diperlukan adanya keselarasan antara laba perusahaan, kepuasan konsumen, dan kepentingan publik (seperti kelestarian lingkungan).

Kotler dan Keller (2009) memberikan konsep holistic marketing sebagai konsep pemasaran terkini. Konsep pemasaran holistik didasarkan pada pengembangan, perencanaan, dan implementasi program pemasaran, proses pemasaran, dan kegiatan-kegiatan pemasaran yang mengakui keluasan dan interdependensi mereka. Pemasaran holistik mengakui bahwa "segala sesuatu bisa terjadi" pada pemasaran dan bahwa pemasaran membutuhkan perspektif yang luas dan terpadu (Thamrin dan Tantri, 2014). Dimensi pokok holistic marketing terdiri atas tempat elemen (Keller dan Kotler, 2012):

a. Internal marketing (pemasaran internal), yang berusaha memastikan bahwa setiap individu dalam organisasi memahami dan menerapkan prinsip pemasaran secara memadai.

b. Intergrated marketing (pemasaran terintegrasi), yang berusaha memastikan bahwa relasi 'win-win' terbina harmonis dengan para pelanggan, karyawan, investor, anggota saluran distribusi, dan mitra pemasaran lainnya.

c. Relationship marketing (pemasaran hubungan), yang memastikan bahwa berbagai teknik, cara, dan wahana, untuk menciptakan, menyampaikan, dan mengomunikasikan nilai diterapkan dan diintegrasikan secara optimal. 
Tujuan utamanya adalah mengembangkan hubungan agar bertahan lama dan mendalam dengan semua orang atau organisasi yang dapat secara langsung atau tidak langsung memengaruhi keberhasilan kegiatan pemasaran perusahaan.

d. Performance marketing (pemasaran kinerja), yang memastikan bahwa dampak keputusan pemasaran terhadap kinerja finansial, ekuitas merek, sosial, legal, etika, komunitas, dan lingkungan benar-benar diperhitungkan secara matang.

\section{PANGSA PASAR DAN BAURAN PEMASARAN}

\section{Pangsa Pasar}

Menurut Kotler dan Keller (2009), beberapa peneliti mencoba mendefinisikan segmentasi dengan melihat dari beberapa pandangan karakteristik:

a. Geografis. Segmentasi geografis, membagi pasar menjadi beberapa unit geografis, seperti negara, daerah, kota, atau lingkungan. Perusahaan dapat mengoperasikan satu atau beberapa area, atau mengoperasikan semuanya, tetapu tetap memberi perhatian pada cariasi lokal.

b. Demografis. Segmentasi psikografis, ilmu pengetahuan psikologi dan demografi untuk lebih memahami konsumen. Pembeli dibagi menjadi kelompok-kelompok yang berbeda berdasarkan psikologis atau karakter kepribadian, gaya hidup, 
dan nilai-nilai. Orang yang berada dalam kelompok demografis yang sama dapat menunjukan profil psikografis yang berbeda.

c. Psikografis. Segmentasi psikografis, ilmu pengetahuan psikologi dan demografi untuk lebih memahami konsumen pembeli dibagi menjadi kelompok-kelompok yang berbeda berdasarkan psikologis atau karakter kepribadian, gaya hidup, dan nilai-nilai. Orang yang berada dalam kelompok demografis yang sama dapat menunjukan profil psikografis yang berbeda.

\section{Bauran Pemasaran}

Menurut Ebert dan Griffin (2003) dalam merencanakan dan melaksanakan strategi, para manajer bergantung pada empat komponen dasar. Elemen itu sering kali disebut sebagai " $4 \mathrm{P}$ " dalam pemasaran, dan disebut sebagai alat untuk menjalankan strategi, mereka membentuk bauran pemasaran masing-masing adalah:

a. Product. pemasaran dimulai dengan produk yaitu, barang, jasa atau gagasan yang dirancang untuk memenuhi kebutuhan seorang pemakai. Menyusun dan mengembangkan produk baru merupakan tantangan bagi tenaga pemasaran. Memenuhi kebutuhan pemakai sering kali berarti mengubah produk-produk yang telah ada. Salah satu strateginya adalah diferensiasi produk. Diferensiasi produk 
berarti penciptaan suatu produk atau citra produk yang cukup berbeda dengan produk-produk yang telah beredar dengan maksud untuk menarik pelanggan.

b. Price. Memilih harga jual yang paling sesuai kadangkadang juga merupakan tindak penyeimbangan. Di satu sisi, harga harus mendukung beragam biaya: biaya operasi, administrasi dan riset organisasi itu selain juga biaya pemasaran, seperti biaya iklan dan biaya penjual. Di sisi lain, harga tidak dapat terlalu tinggi karena pelanggan dapat berpindah ke produkproduk pesaing.

c. Promosi. Komponen bauran pemasaran yang paling terlihat nyata tidak lain adalah promosi, yang mengacu pada teknik-teknik untuk mengomunikasikan informasi mengenai produk. Promosi merupakan kegiatan terpenting, yang berperan aktif dalam memperkenalkan, memberitahukan dan mengingatkan kembali manfaat suatu produk agar mendorong konsumen untuk membeli produk yang dipromosikan tersebut. Setiap perusahaan harus dapat menentukan dengan tepat alat promosi manakah yang digunakan agar dapat mencapai keberhasilan dalam penjualan untuk mengadakan promosi.

d. Place (distribusi). Distribusi menjadi bagian dari bauran pemasaram yang mempertimbangkan bagaimana menyampaikan produk dari produsen ke pemakai. 
Sering bertambahnya kompleksitas dunia bisnis dan pemasaran, variabel bauran pemasaran pun bertambah. Pemasaran saat ini menambahkan $4 \mathrm{P}$ lain ke dalam bauran pemasaran, $4 \mathrm{P}$ tersebut adalah:

a. People. Variabel ini berhubungan dengan apa yang membedakan kualitas sumber daya manusia (tenaga kerja) yang ada dan karakteristik pelanggan yang dimiliki suatu perusahaan dengan perusahaan pesaing.

b. Physical presence. Berhubungan dengan kondisi fisik suatu toko atau website (situs) perusahaan.

c. Process. Variabel ini berhubungan dengan bagaimana produk disproduksi dan disampaikan kepada pelanggan, bagaimana layanan dan kemudahan akses yang didapat pelanggan dari suatu perusahaan.

d. Physical evidence. Variabel ini berhubungan dengan bagaimana suatu layanan yang dijanjikan benar-benar diwujudkan oleh perusahaan untuk memuaskan pelanggannya. 


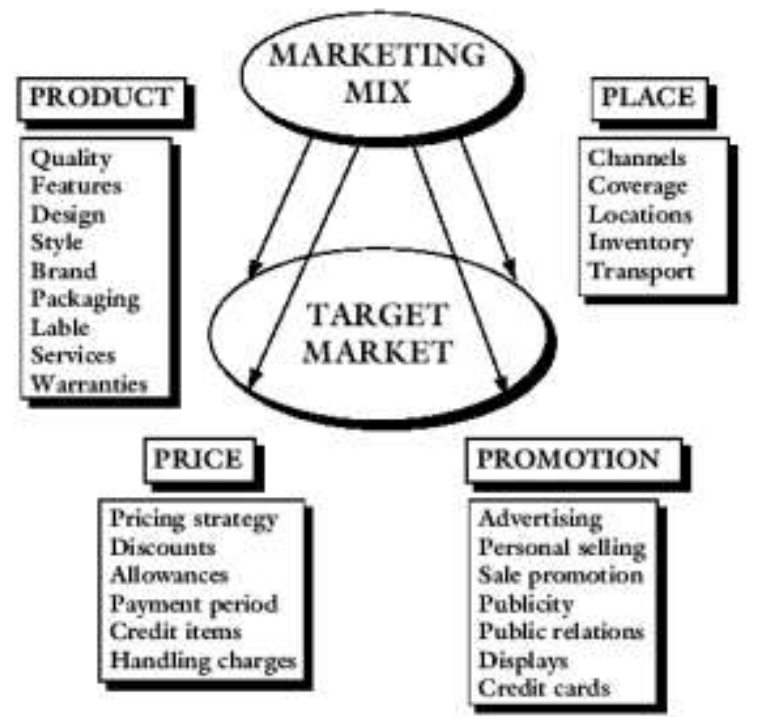

Menurut Swastha dan Irawan dalam Angipora (1999), promosi merupakan insentif jangka pendek untuk mendorong pembelian atau penjualan dari suatu produk atau jasa. Menurut Stanson dalam Angipora (1999), promosi adalah kombinasi strategi yang paling baik dari variabel-variabel periklanan, penjualan personal dan alat promosi yang lain, yang semuanya direncanakan untuk mencapai tujuan program penjualan. Menurut Lamb, Hair, McDaniel (2001), promosi adalah komunikasi dari pada penjual yang menginformasikan, membujuk, dan mengingatkan para calon pembeli suatu produk dalam rangka memengaruhi pendapat mereka atau memperoleh suatu respons. 
Menurut Fandy Tjiptono (2004), bauran promosi tradisional meliputi berbagai metode untuk mengomunikasikan manfaat jasa kepada potensial dan aktual. Metode-metode tersebut terdiri atas periklanan, promosi penjualan, penjualan perseorangan dan hubungan masyarakat. Promosi menunjuk pada berbagai aktivitas yang dilakukan perusahaan untuk mengomunikasikan kebaikan produknya dan membujuk para pelanggan dan konsumen sasaran untuk membeli produk tersebut. Sehingga dapat disimpulkan mengenai promosi yaitu dasar kegiatan promosi adalah komunikasi perusahaan dengan konsumen untuk mendorong terciptanya penjualan.

\section{Bauran Promosi}

Menurut Kotler dan Gary A. dalam Sindoro (2000), bauran promosi adalah ramuan khusus dari iklan pribadi, promosi penjualan dan hubungan masyarakat yang digunakan perusahaan untuk mencapai tujuan iklan dan pemasarannya. Menurut Swastha dalam Marius P. Angipora (1999), promotional mix (bauran promosi) adalah kombinasi strategi yang paling baik dari variabel-variabel periklanan, personal selling dan alat promosi lainnya, yang kesemuanya direncanakan untuk mencapai tujuan program penjualan. Promotion mix terdiri dari:

a. Advertising (periklanan), yaitu segala bentuk presentasi non personal dan promosi ide barang atau jasa oleh sponsor yang ditujuk dengan mendapat bayaran. 
Medianya antara lain: brosur, buklet, poster, penayangan pada audio visual, billboard, dan lain-lain.

b. Sales promotion (promosi penjualan), yaitu bentuk persuasi langsung melalui penggunaan berbagai insentif yang dapat diatur untuk merangsang pembelian produk dengan segera dan atau meningkatkan jumlah barang yang dibeli pelanggan. Medianya antara lain: pemberian training, hadiah, sampel, kupon.

c. Personal selling (penjualan tatap muka), yaitu komunikasi langsung antara penjual dan calon pelanggan untuk memperkenalkan suatu produk kepada calon pelanggan dan membentuk pemahaman pelanggan terhadap produk sehingga mereka kemudian akan mencoba dan membelinya. Medianya antara lain presentasi penjualan, pertemuan penjualan, pasar malam, dan pameran dagang.

d. Direct marketing (pemasaran langsung), yaitu sistem pemasaran beberapa media iklan untuk menimbulkan respons yang terukut dan/atau transaksi di sembarang lokasi. Medianya antara lain pemasaran lewat telepon, internet, surat, dan katalog.

e. Internet. Menurut Ebert dan Griffin (2009), internet adalah sebuah sistem raksasa pada komputer yang paling berhubungan, lebih dari 100 juta komputer di 100 negara yang kita ketahui saat ini. Menurut Kotler dan Armstrong 
(2004), internet adalah jaringan global dari jaringan-jaringan komputer yang luas dan berkembang tanpa ada manajemen atau kepemilikan terpusat. Saat ini, internet menghubungkan individu dan perusahaan satu sama lain dan dengan infomrasi di seluruh dunia. Internet menyediakan koneksi ke informasi, hiburan, dan komunikasi kapan pun dan di manapun.

Perusahaan menggunakan internet untuk membangun hubungan lebih dekat dengan pelanggan dan rekan bisnis serta untuk menjual mendistribusikan produk mereka dengan lebih efektif dan efisien. Menurut Coupey (2001), internet adalah komunikasi antara pelanggan, pasar dan jutaan organisasi. Internet memungkinkan seseroang untuk menentukan cara mereka berkomunikasi, baik dengan orang lain maupun seluruh target pasar secara cepat dan mudah.

Menurut McLeod dan P. Schell (2007), World Wide Web, biasa dikenal dengan sebutan "web" dan " $w w w$ " adalah informasi yang dapat diakses melalui internet di mana dokumen hypermedia (file komputer) yang disimpan kemudian diambil melalui skema pengalamatan. Menurut Herbig dan Hale (2007), world wide web adalah sebuah layanan informasi berbasis hypertext. World wide web menyediakan akses ke multimedia dan dokumen kompleks serta database. 
Menurut Mohammed, et al. (2003) elemen-elemen bauran pemasaran melalui internet terditi dari lima elemen, yaitu:

a. Produk. Layanan atau produk fisik yang ditawarkan oleh perusahaan untuk ditukarkan kepada pelanggan melalui internet.

b. Harga. Sejumlah uang yang harus dibayarkan oleh pelanggan apabila ingin membeli produk yang ditawarkan di internet.

c. Komunikasi. Aktivitas dalam pemasaran melalui internet yang menginformasikan tentang perusahaan dan produknya kepada satu atau lebih kelompok target pelanggan perusahaan.

d. Komunitas. Sekumpulan hubungan yang terbentuk berdasarkan keinginan yang sama bertujuan untuk memenuhi kebutuhan dari anggotanya yang tidak dapat dicapai secara individual.

e. Distribusi. Perpindahan konsep tempat pemasaran dari konsep offilen, di mana pelanggan harus bertemu secara langsung dengan penjual menjadi konsep online, di mana pelanggan melakukan transaksi melalui komputer tanpa batas masalah geografis.

Bauran promosi merupakan program komunikasi pemasaran total sebuah perusahaan yang terdiri dari iklan, penjualan pribadi, promosi penjualan, dan hubungan masyarakat yang digunakan perusahaan untuk mencapai tujuan iklan dan pemasarannya. Menurut Lamb, Hair, McDaniel (2001), bauran promosi yang dipilih oleh suatu perusahaan bagi suatu produk atau jasa tergantung pada beberapa faktor: sifat produk, tahapan dalam 
daur hidup produk, karakteristik target pasar, jenis keputusan pembelian, tersedianya dana untuk promosi, dan menggunakan baik strategi mendorong (push) maupun menarik (pull).

Kotler (2000) mengemukakan berbagai faktor dalam menentukan bauran promosi, yaitu:

\section{a. Tipe produk/pasar.}

1) Perusahaan barang konsumen, biasanya mengalokasikan lebih banyak dana untuk iklan, menyusun promosi penjualan, penjualan perorangan dan kemudian hubungan masyarakat.

2) Perusahaan barang industri, menyediakan dana lebih banyak untuk penjualan perorangan diikuti dengan promosi penjualan, iklan dan hubungan masyarakat.

b. Strategi dorong atau tarik.

1) Strategi dorong (push strategy), merupakan strategi promosi yang menggunakan tenaga penjual dan promosi perdagangan untuk "mendorong" produk lewat saluran distribusi. Produsen mempromosikan produk kepada pedagang besar, pedagang besar kepada pengecer, lalu pengecer mempromosikan kepada konsumen.

2) Strategi tarik (pull strategy), merupakan strategi promosi yang menggunakan banyak biaya untuk periklanan dan promosi konsumen demi memupuk permintaan konsumen. Apabila strategi tarik berhasil konsumen akan mencari produk dari pengecer, 
pengecer akan mencari dari pedagang besar dan pedagang besar akan mencari produsen.

\section{c. Kesiapan pembeli.}

Pengaruh dari alat promosi itu bervariasi untuk tahap kesiapan pembeli yang berbeda. Iklan dan hubungan mesyarakat, memegang peran utama dalam tahap kesadaran dan pengetahuan.

d. Daur hidup produk.

1) Tahap perkenalan. Iklan dan hubungan masyarakat baik untuk menghasilkan kesaran tinggi, dan promosi penjualan bermanfaat untuk memperomosikan penjualan awal. Penjualan perorangan harus dipakai agar pedagang menjual produk tersebut.

2) Tahap pertumbuhan. Semua kiat itu dapat diperlambat karena permintaan memiliki momentumnya sendiri lewat pembicaraan dari mulut ke mulut.

3) Tahap kemapanan (dewasa). Promosi pernjualan, periklanan dan penjualan perorangan semua bertambah penting secara berurutan.

4) Tahap kemunduran. Promosi penjualan berlangsung kuat, iklan dan publisitas dikurangi, dan tenaga penjualan hanya memberi perhatian minimal pada produk itu.

\section{e. Fungsi Promosi.}

Tiga fungsi dari promosi antara lain:

1) Mencari dan mendapatkan perhatian dari calon pelanggan/pembeli. Perhatian calon pelanggan/pembeli harus diperoleh karena ini akan 
menjadi titik awal proses pengambilan keputusan di dalam membeli suatu barang atau jasa.

2) Menciptakan dan menumbuhkan ketertarikan pada diri calon pembeli. Perhatian yang sudah diberikan oleh seseorang mungkin akan dilanjutkan pada tahap berikutnya atau mungkin berhenti. Tahap berikutnya ini artinya timbulnya rasa tertarik dan rasa tertarik ini yang akan menjadi fungsi utama promosi.

3) Pengembangan rasa ingin tahu (desire) calon pembeli untuk memiliki barang yang ditawarkan. Hal ini merupakan kelanjutan dari tahap sebelumnya. Setelah seseorang tertarik pada sesuatu, maka timbul rasa ingin memilikinya. Bagi calon pemberli merasa mampu (dalam harga, cara pemakainnya, dan sebagainya), maka rasa ingin memilikinya ini semakin besar dan diikuti oleh suatu keputusan untuk membeli.

\section{f. Tujuan promosi.}

Beberapa tujuan yang terdapat dalam promosi yaitu:

1) Menginformasikan, maksudnya adalah menginformasikan pasar tentang produk baru, mengemukakan manfaat baru sebuah produk, menginformasikan pasar tentang perubahan harga, menjelaskan bagaimana produk bekerja, menggambarkan jasa yang tersedia, memperbaiki kesan yang salah, mengurangi ketakutan pembeli, membangun citra perusahaan.

2) Membujuk, maksudnya mengubah persepsi mengenai atribut produk agar diterima pembeli. 
3) Mengingatkan, maksudnya agar produk tetap diingat pembeli sepanjang masa, mempertahankan kesadaran akan produk yang paling mendapat perhatian. Setelah diadakan promosi diharapkan konsumen, melakukan pembelian. Pembelian adalah akhir dari proses komunikasi. Pembeli juga memiliki ketertarikan yang tinggi dengan produk yang dikonsumsinya.

Ada enam hal yang dapat dijelaskan komunikasi (Roller, Armstrong, 2000) tersebut yaitu:

1) Kesadaran (awareness). Jika sebagian besar konsumen sasaran tidak menyadari objek tersebut, maka tugas komunikator adalah mengembangkan kesadaran dari mengenai produk dan terus mengenalkan produk kepada konsumen.

2) Pengetahuan (knowledge). Diharapkan konsumen memiliki kesadaran tentang perusahaan atau produk yang telah dikeluarkan dan jangan sampai konsumen tidak mengetahui produk tersebut.

3) Menyukai (liking). Dapat mengetahui perasaan mereka terhadap produk yang dikonsumsi oleh audiensi, sehingga konsumen dapat menyukai produk tersebut.

4) Preferensi (preference). Dapat dikatakan konsumen menyukai produk tersebut dan lebih memilih produk itu dibanding produk lain. 
5) Keyakinan (conviction). Konsumen diharapkan yakin untuk membli produk yang sudah dipilihnya.

6) Pembelian (purchase). Pembelian yang dilakukan konsumen adalah tahap terakhir dalam komunikasi.

Ada empat filosofi pemasaran dan promosi yang mendasari cara organisasi melakukan kegiatan-kegiatan pemasarannya (Kotler, 2000), yaitu:

1) Konsep berwawasan produksi.

Konsep berwawasan produksi berpendapat bahwa konsumen akan memilih produk yang mudah didapat dan murah harganya.

2) Konsep berwawasan produk.

Konsep ini berpendapat bahwa konsumen akan memilih produk yang menawarkan mutu, kinerja terbaik, atau halhal inovatif lainnya.

3) Konsep berwawasan menjual.

Konsep berwawasan menjual berpendapat bahwa konsumen dibiarkan saja, konsumen tidak akan membeli produk organisasi dalam jumlah cukup, artinya konsumen enggan membeli dan harus didorong supaya membeli, serta perusahaan mempunyai banyak cara promosi dan penjualan yang efektif untuk merangsang pembeli.

4) Konsep berwawasan pemasaran.

Dalam konsep ini, bahwa kunci untuk mencapai tujuan organisasi terdiri dari penentuan kebutuhan dan keinginan pasar sasaran serta memberikan kepuasan yang 
diinginkan secara lebih efektif dan efisien daripada saingannya.

\section{TEORI MEREK}

Menurut The American Marketing Asociation (AMA), merek didefinisikan sebagai berikut (Kotler, 2007):

A brand is a name, term, sign, simbol or design or combination of them, intended to indentify The Goss services of one seler or groups selers and diferentiate them from those of competitors.

(Merek adalah nama dan atau simbol yang bersifat membedakan [seperti sebuah cap, logo, atau kemasan] dengan maksud mengidentifikasi barang atau jasa dari seorang penjual atau sekelompok penjual tertentu dengan maksud untuk membedakannya dari barang atau jasa yang dihasilkan oleh para pesaing.)

Sebuah merek menunjukkan kepada pelanggan asal/sumber produk dan melindungi keduanya, produsen dan pelanggan, dari para pesaingnya yang menyajikan produk yang terlihat mirip (Aaker, 2006). Merek dapat juga dibagi dalam pengertian lainnya, seperti:

1. Brand name (nama merek) yang merupakan bagian dari yang dapat diucapkan misalnya, Pepsodent, BMW, Toyota, dan sebagainya.

2. Brand mark (tanda merek) yang merupakan sebagian dari merek yang dapat dikenali namun tidak dapat 
diucapkan, seperti lambang, desain huruf atau warna khusus. Misalnya: simbol Toyoya, gambar trightiga berlian Mitsubishi.

3. Trade mark (tanda merek dagang) yang merupakan merek atau sebagian dari merek yang dilindungi hukum karena kemampuannya untuk menghasilkan sesuatu yang istimewa.

4. Copyright (hak cipta) yang merupakan hak istimewa yang dilindungi oleh undang-undang untuk memproduksi, menerbitkan, dan menjual karya tulis, karya musik atau karya seni.

Merek merupakan janji penjual untuk secara konsisten memberikan feature, manfaat, dan jasa tertentu pada pembeli. Merek terbaik akan memberikan jaminan kualitas. Pemberian nama atau merek pada suatu produk hendaknya tidak hanya merupakan suatu simbol, karena merek memiliki enam tingkatan pengertian, yaitu (Rangkuti, 2004):

1. Atribut. Setiap merek memiliki atribut. Atribut ini perlu dikelola dan diciptakan agar pelanggan dapat mengetahui dengan pasti atribut atribut apa saja yang terkandung dalam suatu merek.

2. Manfaat. Selain atribut, merek juga memiliki serangkaian manfaat. Konsumen tidak membeli atribut, mereka membeli manfaat yang dapat langsung dirasakan konsumen. 
3. Nilai. Merek menyatakan seuatu tentang nilai bagi produsen. Merek yang memiliki nilai tinggi akan dihargai oleh konsumen sebagai merek berkelas, sehingga dapat mencerminkan siapa pengguna merek tersebut.

4. Budaya. Merek mewakili budaya tertentu. Misalnya, Mercedes mewakili budaya jerman yang terorganisasi dengan baik, memiliki cara kerja yang efisien dan selalu menghasilkan produk yang bermutu tinggi.

5. Kepribadian. Merek juga memiliki kepribadian, yaitu kepribadian bagi para penggunanya. Jadi diharapkan dengan menggunakan merek, kepribadian si pengguna akan tercermin bersamaan dengan merek yang digunakan.

6. Pemakai. Merek menunjukkan jenis konsumen pemakai merek tersebut. Itulah sebabnya para pemasar selalu menggunakan analogi orang-orang terkenal untuk penggunaan mereknya.

Temporal (2004) memberikan gambaran bahwa tujuan dari merek adalah memberikan sesuatu yang unik dan menarik dibandingkan dengan pesaing, sehingga dapat memuaskan kebutuhan pelanggan baik secara rasional maupun emosional. Pada saat seseorang memikirkan sebuah produk, ia hanya akan mengaitkannya dengan atribut dan manfaatnya saja, tetapi bila seseorang membayangkn sebuah merek, ia akan melibatkan dimensi emosional di dalamnya. 
Merek merupakan sesuatu yang dicari konsumen ketika datang untuk membeli, sesuatu ini bukan hanya sekedar barang melainkan juga persepsi akan kualitas dan gengsi yang diraih. Citra dan reputasi merek yang terjaga, suatu produk dapat menjadi produk yang bernilai tinggi dan dicari oleh konsumen sehingga nilai perusahaan dapat meningkat diatas nilai riil asetnya (Swa, 2005).

\section{Manfaat Merek}

Merek bermanfaat bagi produsen dan konsumen. Bagi produsen, merek berperan penting sebagai (Keller, dalam Tjiptono, 2005)

a. Sarana identifikasi untuk memudahkan proses penanganan atau pelacakan produk bagi perusahaan, terutama dalam pengorganisasian sediaan dan pencatatan akutansi.

b. Bentuk proteksi hukum terhadap fitur atau aspek produk yang unik. Merek bisa mendapatkan perlindungan properti intelektual. Nama merek bisa diproteksi melalui merek dagang terdaftar (registered trademarks), proses pemanufakturan bisa dilindungi melalui hak paten, kemasan bisa diproteksi melalui hak cipta (copyrights) dan desain. Hak-hak properti intelektual ini memberikan jaminan bahwa perusahaan dapat berinvestasi dengan aman dalam merek yang dikembangkan dan meraup manfaat dari aset bernilai tersebut.

c. Sinyal tingkat kualitas bagi para pelanggan yang puas, sehingga mereka bisa dengan mudah memilih dan 
membelinya lagi di lain waktu. Loyalitas merek seperti ini menghasilkan predictability dan security permintaan bagi perusahaan dan menciptakan hambatan masuk yang menyulitkan perusahaan lain untuk memasuki pasar.

d. Sarana menciptakan asosiasi dan maksa unik yang membdakan produk daripada pesaing.

e. Sumber keunggulan kompetitif, terutama melalui perlindungan hukum, loyalitas, pelanggan, dan citra unik yang terbentuk dalam benak konsumen.

f. Sumber financial returns, terutama menyangkut pendapatan masa datang. Bagi konsumen, merek bisa memberikan beraneka macam nilai melalui sejumlah fungsi dan manfaat potensial. Keller (2003) mengemukakan tujuh manfaat pokok merek bagi konsumen, yaitu sebagai identifikasi sumber produk, penetapan tanggung jawab pada pemanufaktur atau distributor tertentu, pengurang risiko, penekan biaya pencarian internel dan eksternal, janji atau ikatan khusus dengan produsen, alat simbolis yang memproyeksikan citra diri dan sinyal kualitas.

\section{Brand Awareness}

Brand awareness atau kesadaran merek adalah kesanggupan seorang calon pembeli untuk mengenali, mengingat kembali suatu merek sebagia bagian dari kategori produk tertentu. Bagian dari suatu kategori produk perlu ditekankan karena terdapat suatu hubungan yang kuat antara kategori 
produk dengan merek yang dilibatkan. Kesadaran merek membutuhkan jangkauan kontinum (continum ranging) dari perasaan yang tidak pasti bahwa merek terntu telah dikenal sebelumnya, sehingga konsumen yakin bahwa produk tersebut merupakan satu-satunya merek dalam suatu kelompok porduk (Aaker, 2006). Kontinum ini dapat terwakili dalam tingkatan kesadaran merek yang berbeda seperti ditunjukkan dalam suatu piramida berikut ini:

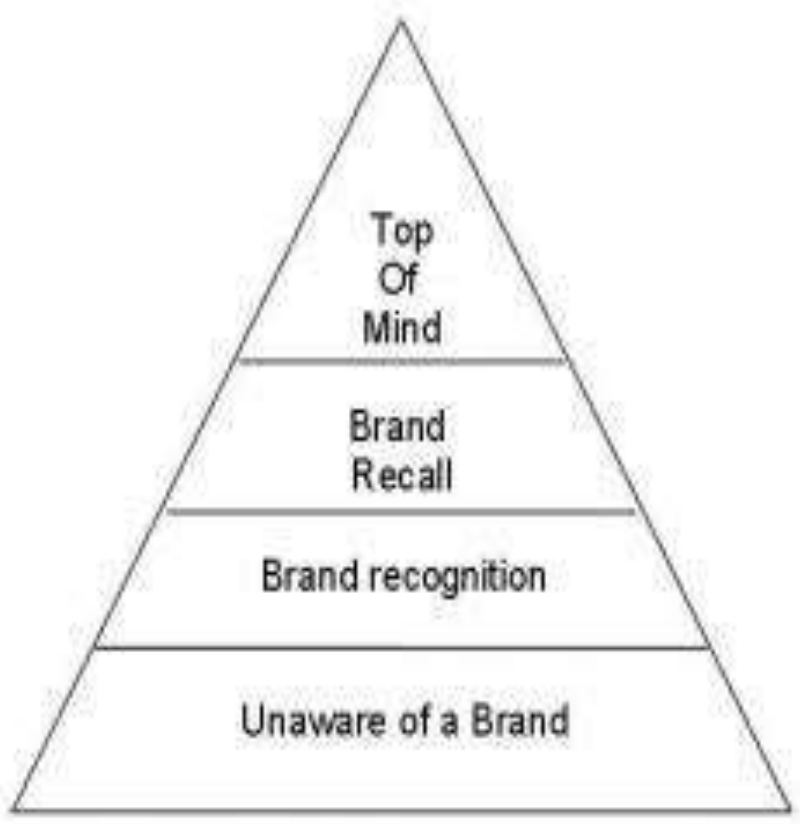




\section{Brand Association}

Brand asociation adalah segala kesan yang muncul di benak seseorang yang terkait dengan ingatannya mengenai suatu merek (Aaker, 2006). Kesan-kesan yang terkait merek akan semakin meningkat dengan semakin banyaknya pengalaman konsumen dalam mengonsumsi suatu merek atau dengan semakin seringnya penampakan merek tersebut dalam strategi komunikasinya, ditambah lagi jika kaitan tersebut didukung oleh suatu jaringan dari kaitan-kaitan lain. Berbagai asosiasi merek yang saling berhubungan akan menimbulkan suatu rangkaian yang disebut brand image (citra merek). Semakin banyaknya asosiasi yang saling berhubungan, semakin kuat citra merek yang dimiliki oleh merek tersebut.

Asosiasi-asosiasi yang terkait dengan suatu merek umumnya dihubungkan dengan berbagai tipe asosiasi merek, yaitu (Aaker, 2006):

a. Product atributes (atribut produk). Mengasosiasikan atribut atau karakteristik suatu produk merupakan strategi positioning yang paling sering digunakan. Mengembangkan asosiasi semacam ini efektif karena jika atribut tersebut bermakna, asosiasi dapat secara langsung diterjemahkan dalam alasan pembelian suatu merek.

b. Intangible atributes (atribut tak berwujud). Suatu faktor tak berwujud merupakan atribut umum, speerti halnya persepsi kualitas, kemajuan teknologi, atau kesan nilai yang mengikhtisarkan serangkaian atribut yang objektif. 
c. Customers benefits (manfaat bagi pelanggan). Sebagian besar atribut produk memberikan manfaat bagi pelanggan, maka biasanya terdapat hubungan antar keduanya. Manfaat bagi pelanggan dibagi dua, yaitu:

1) Rational benefit (manfaat rasional) yang berkaitan erat dengan atribut dari produk yang dapat menjadi bagian dari proses pengembalian keputusan yang rasional.

2) Manfaat psikologis, sering kali merupakan konsekuensi ekstrem dalam proses pembentukan sikap, berkaitan dengan perasaan yang ditimbulkan ketika membli atau menggunakan merek tersebut.

d. Relative price (harga relatif). Evaluasi terhadapt suatu merek di sebagian kelas produk ini akan diawali dengan penentuan posisi merek tersebut dalam satu atau dua dari tingkat harga.

e. Application (penggunaan). Pendekatan ini merupakan suatu cara untuk mengasosiasikan merek tersebut dengan suatu penggunaan atau aplikasi tertentu.

f. User/customer (pengguna/pelanggan). Pendekatan ini adalah dengan mengasosiasikan merek dengan sebuah tipe pengguna atau pelanggan dari produk tersebut.

g. Celebrity (orang terkenal). Mengaitkan orang terkenal atau artis dengan sebuah merek dapat mentransfer asosiasi kuat yang dimiliki oleh orang terkenal ke merek tersebut.

h. Lifestyle/personality (gaya hidup/kepribadian). Asosiasi sebuah merek dengan suatu gaya hidup dapat diilhami oleh asosiasi para pelanggan merek tersebut dengan 
aneka kepribadian dan karakteristik gaya hidup yang hampir sama.

\section{Brand Loyalty}

Brand loyalty merupakan suatu ukuran keterkaitan pelanggan kepada sebuah merek. Ukuran ini mampu memberikan gambaran tentang mungkin tidaknya seorang pelanggan beralih ke merek produk lain, terutama jika pada merek (Aaker, 2006). Seorang pelanggan yang sangat loyal kepada suatu merek tidak akan dengan mudah memindahkan pembeliannya ke merek lain, apa pun yang terjadi dengan merek tersebut. Bila loyalitas pelanggan terhadap suatu merek meningkat, kerentanan kelompok pelanggan tersebut dari ancaman dan serangan merek produk pesaing dapat dikurangi.

Sebaliknya, pelanggan yang tidak loyal kepada suatu merek, pada umumnya pembelian yang dilakukan terhadap merek tersebut tidak didasarkan karena ketertarikan mereka terhadap mereknya namun lebih didasarkan pada karakterisitik produk, harga dan kenyamanan pemakaiannya. Kaitannya dengan brand loyalty suatu produk, didapati adanya beberapa tingkatan brand loyaltyi. Masing-masing tingkatannya menunjukkan tantangan pemasaran yang harus dihadapi. Adapun tingkatan brand loyalty tersebut, yaitu (Aaker, 2006):

a. Switcher (berpindah-pindah). 
Pelanggan yang berada pada tingkat loyalitas ini dikatakan sebagai pelanggan yang berada pada tingkat paling dasar. Semakin tinggi frekuensi pelanggan untuk memindahkan pembeliannya dari suatu merek ke merek-merek yang lain mengindikasikan merek sebagai pembeli yang sama sekali tidak loyal atau tidak tertarik pada merek tersebut. Ciri yang paling nampak dari jenis pelanggan ini adalah merek membeli suatu produk karena harganya murah.

b. Habitual buyer (pembeli yang bersifat kebiasaan).

Pembeli yang berada dalam tingkat loyalitas ini dapat di kategorikan sebagai pembeli yang puas dengan merek produk yang dikonsumsinya atau setidaknya mereka tidak mengalami ketidakpuasan dalam mengonsumsi merek produk tersebut.

c. Satisfied buyer (pembeli yang puas dengan biaya peralihan).

Pada tingkatan ini, pembeli merek masuk ke dalam kategori puas bila mereka mengonsumsi merek tersebut, meskipun demikian mungkin saja memindahkan pembeliannya ke merek lain dengan menanggung switching cost (biaya peralihan) yang terkait dengan waktu, uang, atau risiko kinerja yang melekat dengan tindakan mereka berlaih merek. Untuk dapat menarik minat para pembeli yang masuk dalam tingkat loyalitas ini maka para pesaing perlu mengatasi biaya peralihan yang harus ditanggung oleh pembeli yang masuk dalam kategori ini dengan 
menawarkan berbagai manfaat yang cukup besar sebagai kompensasinya (switching cost loyal).

d. Likes the brand (meyukai merek).

Pembeli yang masuk dalam kategori loyalitas ini merupakan pembeli yang sungguh-sungguh menyukai merek tersebut. Pada tingkatan ini dijumpai perasaan emsional yang terkait pada merek. Rasa suka pembeli bisa saja didasari oleh asosiasi yang terkait dengan simbol, rangkaian pengalaman dalam penggunaan sebelumnya baik yang di alami pribadi maupun oleh kerabatnya ataupun disebabkan oleh kesan kualitas yang tinggi. Sering kali rasa suka ini ditelusuri dengan ceramat untuk dikategorikan ke dalam sesuatu yang spesifik.

e. Commited buyer (pembeli yang setia).

Pada tahapan ini pembeli merupakan pelanggan yang setia. Mereka memiliki suatu hubungan kebanggaan sebagai pengguna suatu merek dan bahkan merek tersebut menjadi sangat penting bagi mereka dipandang dari segi fungsinya maupun sebagai suatu ekspresi mengenai siapa sebenarnya mereka. Pada tingkatan ini, salah satu aktualisasi loyalitas pembeli ditunjukkan oleh tindakan merekomendasikan dan mempromosikan merek tersebut kepada pihak lain.

\section{Perceived Quality}

Aaker (2006) mendefinisikan perceived quality (kesan kualitas) sebagai persepsi pelanggan terhadap keseluruhan 
kualitas keunggulan suatu produk atau jasa layanan berkaitan dengan apa yang diharapkan oleh pelanggan, karena merupakan kesan dari pelanggan maka perceived qualityi tidak dapat ditentukan secara objektif. Persepsi pelanggan akan melibatkan apa yang penting bagi pelanggan karena setiap pelanggan memiliki kepentingan (yang diukur secara relatif) yang berbeda-beda terhadap suatu produk dan jasa. Perceived quality akan membentuk persepsi kualitas keseluruhan terhadap suatu produk atau jasa dapat menentukan nilai dari produk atau jasa tersebut dan berpengaruh secara langsung kepada keputusan pembelian konsumen dan loyalitas mereka terhadap merek.

Perceived quality mencerminkan perasaan pelanggan secara menyeluruh mengenai suatu merek. Perceived quality juga berlaku untuk jasa layanan yang melibatkan dimensi kualitas jasa seperti waktu tunggu, keramahan petugas, kenyamanan ruangan, dan lain sebagainya.

Aaker (2006) membagi kualitas produk menjadi tujuh dimensi, yaitu:

a. Performance; melibatkan berbagai karakteristik operasional utama, misalnya karakteristik operasional mobil adalah kecepatan, ekselerasi, sistem kemudi, serta kenyamanan. Faktor kepentingan pelanggan berbeda satu sama lain, sering kali pelanggan mempunyai sikap yang berbeda dalam menilai atribut-atribut ini. Kecepatan akan 
diberi nilai tinggi oleh sebagian pelanggan lain yang lebih mementingkan atribut kenyamanan.

b. Serviceability; mencerminkan kemampuan memberikan pelayanan pada produk tersebut. Misalnya mobil merek tertentu yang memosisikan dirinya sebagai mobil tahan lama walau telah berumur 12 tahun tetapi masih berfungsi dengan baik.

c. Reability. Konsistensi dari kinerja yang dihasilkan suatu produk dari satu pembelian ke pembelian berikutnya.

d. Features: bagian-bagian tambahan dari produk (feature), seperti remote control sebuah video, tape deck, sistem WAP untuk telepon genggam. Penambahan ini biasanya digunakan sebagai pembeda yang penting ketika dua merek produk terlihat hampir sama. Bagian-bagian tambahan ini memberi penekanan bahwa perusahaan memahami kebutuhan pelanggannya yang dinamis sesuai perkembangan.

e. Conformance with spesifications: merupakan pandangan mengenai kualitas manufaktur (tidak ada cacat produk) sesuai dengan spesifikasi yang telah ditentukan teruji. Misalnya, sebuah mobil pada kelas tertentu dengan spesifikasi yang telah ditentukan seperti jenis dan kekuatan mesin, pintu, dan material untuk pintu mobil, ban, sistem pengapian dan lainnya.

f. Fit and finish: mengarah kepada kualitas yang dirasakan yang melibatkan enam dimensi sebelumnya. Jika perusahaan tidak dapat menghasilkan "hadil akhir" produk yang baik maka kemungkinan produk tersebut tidak akan mempunyai kualitas lain yang penting. 
Dimensi-dimensi untuk konteks jasa serupa tapi tidak sama dengan dimensi konteks produk. Untuk kualitas pelayanan jasa masih menurut Aaker (2006), ada lima dimensi, yaitu:

a. Tangibles (bentuk fisik), apakah karakteristik fisiknya (fasilitas fisik, perlengkapan, dan penampilan pekerjaannya) mengesankan kualitas.

b. Reliability (kehandalan) yang sangat tergantung pada kinerja yang diberikan.

c. Responsivenes (ketanggapan), adanya tanggung jawab dan kecakapan karyawan dalam membantu dan membrikan pelayanan sebaik-baiknya.

d. Competences (jaminan) yang mencakup kompetensi baik dari segi pengetahuan dan keahlian dalam memberikan pelayanan atau tugas dengan kredibilitas tinggi.

e. Empathy (empati) menunjukkan rasa peduli dan perhatian pada pelanggan dengan komunikasi yang baik.

\section{E. SEGMENTASI PASAR}

Pasar merupakan tempat yang sangat luas bagi para penjual/pemasar untuk menjual produk atau jasa mereka. Menurut Rosyidi (2009), para ahli ekonomi sampai dengan dewasa ini telah membedakan dua bentuk pasar yang ekstrem, yakni pasar dengan persaingan sempurna (perfect competition) dan pasar dengan monopoli (monopoly). Kedua jenis pasar tersebut memiliki karakteristik yang sangat jauh berbeda, namun tidak berarti hanya ada dua jenis pasar dalam 
perekonomian. Jenis pasar dibagi menjadi empat yang dibedakan berdasarkan bentuk dan strukturnya (jumlah firm/perusahaan yang terlibat) yaitu pasar persaingan sempurna, pasar persaingan tidak sempurna (monopolistik), oligopoli, dan monopoli. Berikut adalah matriks keempat pasar tersebut:

\begin{tabular}{|c|c|c|}
\hline \multirow{2}{*}{ FIRMA } & \multicolumn{2}{|c|}{ PRODUK } \\
\cline { 2 - 3 } & Homogen & Terbedakan \\
\hline \multirow{2}{*}{ Banyak } & $\begin{array}{c}\text { Persaingan } \\
\text { sempurna }\end{array}$ & $\begin{array}{c}\text { Persaingan } \\
\text { monopolistik }\end{array}$ \\
\hline Sedikit & & Oligopoli \\
\hline Satu & & Monopoli \\
\hline
\end{tabular}

Perusahaan baru tidak akan mudah untuk memasuki suatu pasar yang sudah lama tercipta dan beroperasi. Perusahaan baru tersebut harus mampu beradaptasi dengan kondisi pasar yang ingin dimasukinya. Segmentasi pasar, menetapkan pasar sasaran, dan menentukan posisi pasar perlu dipertimbangkan dengan baik bagi sebuah perusahaan yang ingin berhasil dalam mamsuki suatu pasar.

Menurut Kasmir (2008), segmentasi pasar adalah kegiatan memilah-milah atau membagi pasar menjadi 
beberapa bagian yang bertujuan untuk memberikan kemudahan kepada sebuah perusahaan untuk menentukan pasar sasaran atau konsumen yang akan dituju. Segmentasi pasar dapat dilakukan atau berdasarkan geografi, demografi, psikografi, atau berdasarkan perilaku. Ada empat jenis segmen yang dikenal secara global dalam industri pasar:

1. Company loyal, artinya pelanggan sekarang ini hampir tidak akan beralih ke perusahaan lain (pesaing).

2. Competitive, artinya pelanggan sekarang ini memiliki peluang atau berpotensi pindah atau beralih ke perusahaan lain (pesaing).

3. Switchable, artinya pelanggan pesaing sekarang ini memiliki peluang atau berpotensi pindah atau beralhi ke perusahaan lain (pesaing).

4. Competitor loyal, artinya pelanggan pesaing sekarang ini hampir tidak akan pindah atau beralih ke perusahaan lain (pesaing).

Setelah dilakukan segmentasi pasar, maka langkah selanjutnya adalah menetapkan pasar sasaran. Penetapan pasar sasaran harus dilakukan dengan berbagai pertimbangan, karena berkaitan dengan evaluasi terhadap segmen yang ada, yang pada akhirnya dilakuka pemilihan pasar yang dianggap memenuhi syarat (nilai tinggi) dan sesuai dengan tujuan perusahaan yang bersangkutan. Evaluasi segmen pasar meliputi (Kasmir,2008): 
1. Ukuran dan pertumbuhan segmen seperti data tentang usia pelanggan, pendapatan, jenis kelamin, atau gaya hidup dari setiap segmen.

2. Memperhatikan ancaman dari produk pengganti (subtitusi) dari perusahaan lain/pesaing.

3. Sasaran dan sumber daya perusahaan dengan memerhatikan energi yang dimiliki perusahaan, seperti ketersediaan sumber daya manusia termasuk keterampilan yang dimilikinya.

Sementara itu, kegiatan memilih segmen dapat dilakukan dengan dua cara, yakni:

1. Pemilihan segmen pasar yang dibedakan berdasarkan jumlah biaya total yang dibelanjakan oleh perusahaan. Cara pertama ini terdiri dari tiga cara:

a. Pemasaran serba sama, melayani semua pasar dan tawaran pasar (tidak ada perbedaan). Perusahaan mencari paa yang sama dalam kebutuhan konsumen. Biasanya untuk produk massal seperti bahan-bahan pokok untuk semua orang, baik usia, pendapatan, maupun wilayah. Keuntungan pemasaran serba sama adalah hemat biaya.

b. Pemasaran serba-aneka, merancang tawaran untuk semua pendapatan, tujuan, atau kepribadian. Pemasaran ini memerlukan biaya yang tinggi. 
c. Prmasaran terpadu, khusus untuk perusahaan yang memiliki tenaga kerja (sumber daya manusia) yang terbatas.

2. Pemilihan segmen pasar berdasarkan keunggulan atau spesialisasi yang dimiliki oleh perusahaan. Pemilihan segmen pasar ini terdiri dari lima alternatif, yaitu:

a. Single segment concentration, artinya perusahaan dapat memilih potensial dan menguntungkan perusahaan. Pertimbangan penggunaan alternatif ini adalah keterbatasan dana, segmen tersebut belum tergarap dan cenderung diabaikan pesaing.

b. Selection specialiation, merupakan cara untuk memilih sejumlah segmen yang menarik dan sesuai dengan tujuan serta tenaga kerja yang dimiliki perusahaan. Masing-masing segmen yang tersedia memiliki sinergi yang sama kuat, sehingga perlu dipilih secara hati-hati.

c. Market specialisation, dimana perusahaan melakukan segmentasi dengan mengkhususkan diri untuk melayani berbagai kebutuhan dan sekelompok pelanggan tertentu saja

d. Product specialiation, merupakan cara perusahaan untuk hanya memfokuskan kepada produk yang kemudian dijual kepada berbagai segmen pasar.

e. Full market coverage, yaitu perusahaan melakukan atau melayani semua segmen yang 
ada dengan semua produk yang mungkin dibutuhkan tanpa adanya batasan tertentu.

Langkah terakhir adalah menentukan posisi pasar (market positioning), di mana perusahaan harus mampu mengambil posisi yang potetitif untuk produk atau suatu pasar. Kasmir (2008) berpendapat bahwa produk atau jasa seharusnya diposisikan pada posisi yang diinginkan oleh pelanggan, sehingga dapat menarik minat pelanggan untuk membeli produk atau jasa yang ditawarkan. Lebih lanjut, Kasmir (2008) menjelaskan tiga strategi yang dapat digunakan perusahaan dalam menentukan posisi pasar terdiri dari:

1. Mengidentifikasi keunggulan kompetitif (diferensiasi produk, jasa, personil, dan citra);

2. Memilih keunggulan kompetitif yang tepat yakni memilih yang paling banyak memberikan keunggulan dengan pertimbangan, a) ada berapa banyak perbedaan yang mungkin dapat dipromosikan, dan b) perbedaan mana yang akan dipromosikan;

3. Mewujudkan dan mengmunikasikan posisi yang dipilih ke berbagai pihak yang berkepentingan.

Segemntasi pasar, penetapan pasar sasaran, dan penentuan posisi pasar merupakan tiga hal yang penting yang tidak boleh dikesampingkan oleh sebuah perusahaan sebelum melakukan kegiatan pemasaran, 
utamanya bagi perusahaan baru. Tujuannya adalah untuk mengetahui seberapa besar pasar yang akan dimasuki, siapa yang menjadi konsumen produk yang ditawarkan, dan seberapa besar pesaing yang dihadapi (Kasmir, 2008). 


\section{BAB II \\ Pemasaran Prespektif Syariah}

\section{A. Definisi Pemasaran Syariah}

Pasar merupakan bagian penting dalam kehidupan seorang Muslim da bisa dijadikan katalisator hubungan transcendental Muslim dengan Tuhannya, dengan kata lain bertransaksi dalam pasar merupakan ibadah seorang Muslim dalam kehidupan ekonomi. Hal tersebut pernah dilakukan oleh Rasulullah ketika hijrah ke Madinah, yang mana beliau banyak pergi ke pasar untuk memenuhi kebutuhan hidupnya. Fenomena ini memancing pertanyaan bagi kaum Quraisy. Firman Allah dalam surah al-Furqaan (25) ayat 7:

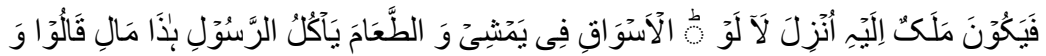

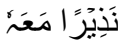

Dan mereka berkata: "Mengapa Rasul itu memakan makanan dan berjalan dipasar-pasar? Mengapa tidak diturunkan kepadanya seorang malaikat agar malaikat itu memberikan peringatan bersama-sama dengan dia?"

Selain itu dapat juga dilihat firman Allah dalam surah alfurqaan (25) ayat 20:

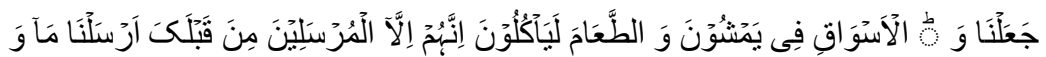

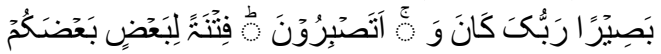


Dan kami tidak mengutus Rasul-rasul sebelummu, melainkan mereka sungguh memakan makanan dan berjalan dipasar-pasar. Dan kami jadikan sebahagian kamu cobaan bagi sebahagian yang lain. Maukah kamu bersabar?; dan adalah Tuhanmu Maha melihat.

Pemasaran sering kali disalahartikan sebagai kegiatan penjualan semata. Padahal pemasaran bukanlah suatu cara sederhana sekadar untuk menghasilkan penjualan saja, penjualan hanyalah satu tahap dalam proses pemasaran. Sebenarnya, kegiatan pemasaran telah dilakukan baik sebelum maupun sesudah terjadi penjualan. (Swastha, 1981).

\begin{tabular}{|l|l|l|}
\hline & PENJUALAN & PEMASARAN \\
\hline Falsafah & $\begin{array}{l}\text { Menjual apa yang bisa } \\
\text { dibuat }\end{array}$ & $\begin{array}{l}\text { Membuat apa yang bisa } \\
\text { dijual }\end{array}$ \\
\hline Titik awal & Pabrik & Pasar sasaran \\
\hline Pusat & $\begin{array}{l}\text { Kegiatan yang hanya } \\
\text { fokus pada menjual } \\
\text { produk, dan bertujuan } \\
\text { untuk meningkatkan } \\
\text { penjualan produk saja }\end{array}$ & $\begin{array}{l}\text { Merencanakan produk, } \\
\text { menetapkan harga, } \\
\text { mempromosikan } \\
\text { mendistribusikan barang } \\
\text { yang bertujuan untuk } \\
\text { memuaskan konsumen. }\end{array}$ \\
\hline Sasaran & $\begin{array}{l}\text { Menjual dan promosi } \\
\text { Pemasaran }\end{array}$ \\
\hline
\end{tabular}




\begin{tabular}{|l|l|l|}
\hline & & terkoordinasi \\
\hline Tujuan & $\begin{array}{l}\text { Keuntungan melalui } \\
\text { volume penjualan }\end{array}$ & $\begin{array}{l}\text { Keuntungan melalui } \\
\text { kepuasan konsumen }\end{array}$ \\
\hline Personalia & $\begin{array}{l}\text { Penjual dan tenaga } \\
\text { promosi }\end{array}$ & Semua personalia \\
\hline
\end{tabular}

Pasar syariah adalah pasar yang emosional (emotiona Imarket) sedangkan pasar konvensional adalah pasar yang rasional (rationa Imarket). Maksudnya orang tertarik untuk berbisnis pada pasar syariah karena alasan-alasan keagamaan (dalam hal ini agama Islam) yang lebih bersifat emosional, bukan karena ingin mendapatkan keuntungan finansial yang bersifat rasional. Sebaliknya, pada pasar konvensional atau non-syariah. orang ingin mendapatkan keuntungan yang sebesar-besarnya, tanpa terlalu peduli apakah bisnis yang digelutinya dan cara hasil tersebut mungkin menyimpang atau malah bertentangan dengan prinsip syariah.( Al Arif, 2010)

Seorang pakar ekonomi syariah Hafidhudin mengatakan bahwa orang-orang yang ada di pasar syariah justru sebenarnya sangat rasional dalam menentukan pilihan. Beliau juga mengatakan, orang yang berada dalam kategori pasar emosional biasanya lebih kritis, lebih teliti dan sangat cermat dalam membandingkan dengan bank atau asuransi konvensional yang selama ini digunakannya sebelum menentukan pilihannya ke pasar syariah. Pernyataan ini ada benarnya melihat pendapat seorang praktisi perbankan syariah tentang dikotomi pasar 
emosional dan pasar rasional, Budi Wicakseno mengatakan, bahwa pemahaman dikotomi antara nasabah rasional dan nasabah emosional adalah keliru. Cara berpikir seperti itu. katanya. dilandasi oleh teori pemasaran konvensional yang berpaham sekuler. segala hal yang berlandaskan cara berpikir keagamaan serta-merta akan dianggap sebagai sesuatu yang tidak rasional (Kertajaya dan Sula, 2006).

Praktisi bisnis dan pemasaran sebenarnya bergeser dan mengalami transformasi dari level intelektual (rasional) ke emosional dan akhirnya ke pasar spiritual. Pada akhirnya konsumen akan mempertimbangkan kesesuaian produk dan jasa terhadap nilai-nilai spiritual yang diyakininya. Di level intelektual (rasional), pemasar menyikapi pemasaran secara fungsionalteknikal dengan menggunakan sejumlah tools pemasaran. seperti segmentasi, targeting, positioning. marketing-mbz. branding dan sebagainya. Kemudian di level emosional. kemampuan pemasar dalam memahami emosi dan perasaan pelanggan menjadi penting. Di sini pelanggan dilihat sebagai manusia leutuhnya, lengkap dengan emosi dan perasaannya. Spiritual market ing merupakan angkatan tertinggi. Orang ndak nemata-mata menghitung untung atau rugi. tidak terpengaruh lagi dengan hal yang bersifat duniawi. Panggilan jiwa yang mendorongnya. karena di dalamnya terkandung nilai-nilai spiritual.

Selain itu dalam syariah marketing, bisnis yang disertai keikhlasan semata-mata hanya untuk mencari keridhaan Allah, maka seluruh bentuk transaksinya insya Allah menjadi ibadah dihadapan Allah. Ini akan menjadi bibit dan modal dasar baginya 
untuk tumbuh menjadi bisnis yang besar, yang memiliki Spiritual brand, yang memiliki kharisma, keunggulan, dan keunikan yang tak tertandingi (Al Arif, 2010).

Stephen R. Covey penulis buku legendaris, The 7 Habit of Highly Effective People, di penghujung kariernya dia menerbitkan buku baru, The $8^{\text {th }}$ Habit: From Effectiveness to Greatness, menyimpulkan bahwa faktor spiritual merupakan kunci terakhir yang harus dimiliki seorang pemimpin dalam suatu perusahaan. Kita perlukan kepemimpinan spiritual dalam mengelola suatu bisnis, terlepas dari mana sumber spiritual tersebut.

Suatu bisnis, sekali pun bergerak dalam bisnis yang berhubungan dengan agama, jika tidak mampu memberikan kebahagiaan kepada semua pihak, berarti belum melaksanakan spiritual marketing. Sebaliknya jika dalam berbisnis kita sudah mampu memberikan kebahagiaan, menjalankan kejujuran dan keadilan, sesungguhnya kita telah menjalankan spiritual marketing, apa pun bidang yang kita geluti selama tidak bertentangan dengan prinsip syariah. dalam bisnis travel, haji misalnya, sekalipun mengurusi orang yang sedang menjalankan ibahadah haji, jika dalam pengelolaannya terdapat penyimpangan-penyimpangan dari segi fasilitas dan akomodasi setelah di Tanah Suci, tidak sesuai dengan yang dijanjikan dan dipromosikan sebelumnya, berarti sesungguhnya bisnis ini tidak berjalan dengan konsep bisnis syariah, ia pun belum menjalankan spiritual marketing. Pemasaran berhubungan dan berkaitan dengan suatu proses mengidentifikasi dan memenuhi kebutuhan manusia dan masyarakat. Salah satu definisi pemasaran yang 
terpendek adalah memenuhi kebutuhan secara menguntungkan (Al Arif, 2010).

Pemasaran menurut Kotler (1997), yaitu: Suatu proses sosial dan manajerial yang membuat individu dan kelompok memperoleh apa yang mereka butuhkan serta inginkan lewat penciptaan dan pertukaran timbal balik produk dengan nilai orang lain. Merupakan suatu fungsi bisnis yang bertugas mengenali kebutuhan dan keinginan pelanggan, menentukan pasar sasaran mana yang dapat dilayani dengan sebaik-baiknya oleh perusahaan, serta merancang produk, jasa, dan program yang tepat untuk layani pasar tersebut.

Adapun definisi pemasaran, menurut World Marketing Association yang diajukan oleh Hermawan Kartajaya (2002), adalah:

Marketing is a strategis business discipline that directs the process of creating offering and changing value from one inisiator to its stakeholders.

Dari definisi di atas, pemasaran merupakan suatu fungsi yang dijalankan perusahaan, hampir semua perusahaan memiliki dan membutuhkan fungsi pemasaran. Fungsi pemasaran juga berkaitan dengan menciptakan, mengomunikasikan dan memberikan nilai kepada pelanggan serta mempertahankan pelanggan. Fungsi ini diwujudkan dalam marketing mix atau bauran pemasaran yang terdiri dari $4 \mathrm{P}$ (product, place, price, and promotion). Pemasaran juga berhubungan dengan customer atau pelanggan, namun perlu dipahami bahwa pemasaran tidak hanya dijalankan oleh satu perusahaan tertentu saja akan tetapi 
perusahaan-perusahaan yang lain juga menjalankannya. Dampak dari ini mengakibatkan produk-produk yang sejenis atau melayani pelanggan yang sama saling bersaing. Itulah sebabnya pemasaran selalu melibatkan persaingan, baik secara langsung maupun tidak langsung.

Di sinilah fungsi pemasaran dibutuhkan untuk peroleh pelanggan, mengembangkan pelanggan dan mempertahankannya. Pesaing pun selalu dipantau agar pelanggan tidak berpindah. Untuk itu, pemasar perlu meramu berbagai strategi dan taktik pemasaran yang berdaya guna. Inilah dinamikanya pemasaran yang selalu berubah dan dibutuhkan marketer yang andal yang memahami baik pelanggan maupun pesaingnya. (Istijanto, 2007)

Kata syariah dalam Mu'jam Alfazh Al-Qur'an Al-Karim yaitu berasal dari kata syara'a al syai'a yang berarti 'menerangkan' atau 'menjelaskan sesuatu'. Atau berasal dari kata syir'ah dan syariat yang berarti 'suatu tempat yang dijadikan sarana untuk mengambil air secara langsung sehingga orang yang mengambilnya tidak memerlukan bantuan alat lain.

Adapun syariat menurut Syekh Yusuf Qardhawi (1990), yang juga dikutip oleh Kartajaya dan Sula (2006), yaitu cakupan dari pengertian syariat menurut pandangan Islam sangat luas dan komperehensif (al-syumul). Di dalamnya mengandung makna mengatur seluruh aspek kehidupan, mulai dari aspek ibadah (hubungan manusia dengan Tuhan), aspek bisnis (perdagangan industri, perbankan, asuransi, utang piutang, pem asaran, 
ghibah), aspek hukum dan peradilan, aspek undang-undang hingga hubungan antar negara (Kertajaya dan Sula, 2006).

Dalam Al-Qur'an kata syariat disebutkan hanya sekali dalam surah al-jatsiyaah ayat 18 :

Kemudian kami jadikan kamu berada di dalam suatu syariat (peraturan) dari urusan (agama) itu, maka ikutilah syariat itu dan janganlah kalu mengikuti hawa nafsu orang-orang yang tidak mengetahui.

Kemudian kata itu muncul dalam bentuk kerja dan turunnya sebanyak tiga kali.

Dia telah mensyariatkan bagi kamu tentang agama apa yang telah diwasiatkan-Nya kepada Nuh dan apa yang telah Kami wahyukan kepadamu, dan apa yang telah kami wasiatkan kepada Ibrahim, Musa, dan Isa. . .(QS. as-Syura: 13)

Untuk tiap-tiap umat di antara kamu. Kami berikan aturan dan jalan yang terang. (QS. al-Maidah: 48)

Apakah mereka mempunyai sembahan-sembahan selain Allah yang mensyariatkan untuk mereka agama yang tidak diizinkan Allah? Sekiranya tak ada ketetapan yang menentukan (dari Allah), tentulah mereka telah dibinasakan. Dan sesungguhnya orangorang yang zalim itu akan memperoleh azab yang amat pedih. (QS. asy-Syuraa: 21) 
Dari definisi dua kata tersebut maka dapat disimpulkan bahwa pemasaran syariah adalah sebuah disiplin bisnis strategis yang mengarahkan proses penciptaan, penawaran dan perubahan value dari suati inisiator kepada stakeholder-nya, yang dalam keseluruhan prosesnya sesuai dengan akad dan prinsip-prisip muamalah (bisnis) dalam islam. Dan merupakan salah satu bentuk muamalah yang dibenarkan dalam islam, sepanjang dalam segala proses transaksinya terpelihara dari hal-hal yang terlarang oleh ketentuan syariah. (syariah marketing is a strategic businedd discipline that directs the process of creating, offering and canging value from one inisiator to its stakeholders, and the whole process should be in accordance with muamalah principles in Islam) (Kertajaya dan Sula 2006).

Adapun menurut Abdullah (2006) pemasaran dalam perspektif syariah adalah segala aktivitas bisnis dalam perkegiatan penciptaan nilai (value creaating activities) yang memungkinkan pelakunya bertumbuh serta mendayagunakan kemanfaatannya yang dilandasi dengan kejujuran, keadilan, keterbukaan dan keikhlasan sesuai proses yang berprinsip pada akad bermuamalah islami.

Definisi di atas didasarkan pada salah satu ketentuan dalam bisnis Islami yang tertuang dalam sebuah Hadis sekaligus menjadi kaidah fikih, yaitu (Kertajaya dan Sula, 2006):

"kaum Muslim terkait dengan kesepakatan-kesepakatan bisnis yang mereka buat, kecuali kesepakatan yang mengharamkan yang 
halal atau mengahalalkan yang haram" (HR. Tirmidzi, dalam AtTirmidzi IV, 1965: 584)

Dalam kaidah fikih lainnya dikatakan pula (Kertajaya dan Sula 2006):

"pada dasarnya hal-hal yang terkait mu'amalah itu dibolehkan kecuali ada dalil yang mengharamkannya."

Ini artinya bahwa dalam pemasaran syariah seluruh proses baik proses penciptaan, proses penawaran, maupun proses perubahan nilai (value) tidak boleh ada hal-hal yang bertentangan dengan akad dan prinsip-prinsip muamalah yang islami, sepanjang hal tersebut dapat dijamin dan penyimpanan prinsip-prinsip muamalah islami tidak terjadi dalam suatu transaksi apa pun atau dalam proses suatu bisnis, maka bentuk transaksi apa pun dalam pemasaran dapat dibolehkan (Kertajaya dan Sula, 2006).

Tujuan dari penerapan syariah adalah untuk kemaslahatan manusia karena Allah ta'alai menurunkan perintah maupun larangan agar terjaga keseimbangan dalam kehidupan dan manusia memperoleh kemaslahatan bagi dirinya. Al-Syatibi mengatakan bahwa (Romli, 2007):

"ketentuan-ketentuan hukum yang disyariatkan Allah untuk kemaslahatan manusia."

Dalam perkataan lainnya disebutkan juga bahwa (Romli, 2007): 
"sebagian besar jumhur ulama telah sepakat bahwa Allah Yang Mahasuci Dia tidak mensyariatkan hukum-hukum-Nya kecuali untuk tujuan yang sifatnya menyeluruh dan tujuan tersebut adalah untuk mewujudkan dan meraih manfaat (kemaslahatan) bagi umat manusia dan sekaligus menghindarkan mereka dari kerusakan serta membebaskan dunia dari kejahatan dan dosa."

Nilai ketauhidan juga termanifestasi dalam aktivitas pemasaran syariah. hal inilah yang menyebabkan setiap aktivitas pemasaran syariah senantiasa berlandaskan atas sikap ketundukan dan ketaatan terhadap nilai-nilai moral yang telah diatur oleh syariah. setiap Muslim yang taat, memiliki keyakinan bahwa Allah Ta'ala adalah tujuan akhir dari setiap aktivitas, serta kecintaan kepada Allah Ta'ala adalh puncak dari seluruh aktivitas spiritual. Ibnu al-Qayyim mengatakan bahwa aktivitas ibadah kepada Ar-Rahman adalah puncak dari rasa cinta kepada-Nya, yang diiringi puncak perasaan rendah dari seorang hamba di hadapan-Nya (Abdurrahman, 2009).

Pemasaran syriah bukan hanya sebuah pemasaran yang ditambahkan syariah karena ada nilai-nilai lebih pada pemasaran syariah saja, tetapi lebih jauhnya pemasaran berperan dalam syariah, dan syariah berperan dalam pemasaran. Pemasaran berperan dalam syariah diartikan perusahaan yang berbasissyariah diharapkan dapat bekerja dan bersikap profesional dalam dunia bisnis, karena dengan profesionalitas dapat menumbuhkan kepercayaan konsumen. Syariah berperan dalam pemasaran bermakna suatu pemahaman akan pentingnya nilai-nilai etika dan moralitas pada pemasaran, sehingga 
diharapkan perusahaan tidak akan serta merta menjalankan bisnisnya demi keuntungan pribadi saja ia juga harus berusaha untuk menciptakan dan menawarkan bahkan dapat merubah suatu values kepada para stakeholders sehingga perusahaan tersebut dapat menjga keseimbangan laju bisnisnya sehingga menjadi bisnis yang sustainable.

Dalam pandangan Kertajaya (1999) telah terjadi pergeseran orientasi perusahaan dari pemasaran yang masih berorientasi perusahaan (marketing oriented company) menjadi perusahaan yang fokus pada pelanggan (customer driven company). Pergerseran tersebut dipicu oleh situasi persaingan pada saat itu. Apabila situasi persaingan rendah atau bahkan tidak ada persaingan, maka pemasaran tidak atau belum terlalu dibutuhkan perusahaann. Apabila dalam situasi persaingan yang semakin keras maka fungsi pemasaran menjadi semakin penting di dalam perusahaan. Adapun pada situasi persaingan yang sangat keras, tidak dapat diduga dan kacau, maka pemasaran harus menjadi jiwa setiap orang di dalam perusahaan tersebut.

Dunia pemasaran sering pula di dalam perusahaan tersebut, yang penuh janji manis namun belum tentu terbukti apalah produknya sesuai dengan apa yang telah dijanjikan. Inilah yang harus dibuktikan dalam suatu manajemen pemasaran syariah baik pada penjualan produk barang atau jasa, bahwa pemasaran syariah bukanlah dunia yang penuh dengan tipu menipu. Sebab pemasaran syariag merupakan tingkatan paling tinggi dalam pemasaran yaitu spiritual marketingm di mana etika, nilai-nilai, dan norma dijunjung tinggi. Hal-hal inilah yang sering 
kali dilanggar oleh pemasaran konvensional, sehingga menyebabkan konsumen pada akhirnya banyak yang kecewa pada produk barang atau jasa yang telah dibeli karena berbeda dengan apa yang telah dijanjikan oleh para pemasar (Al Arif, 2010).

\section{B. Pemasaran dalam Prespektif Syariah}

Pemasaran memiliki peran yang sangat penting dalam memenuhi kebutuhan konsumen, di samping pencapaian tujuan perusahaan. Dalam memenuhi tujuan ini. Seorang pemasar Muslim harus memastikan bahwa semua aspek kegiatan pemasaran, seperti halnya teknik promosi yang digunakan, haruslah sesuai dengan tuntunan Al-Qur'an dan As-Sunnah, (Abdullah dan Ahmad, 2010). Maka penerapan dalam syariah akan merujuk pada konsep dasar kaidah fikih yakni (Kertajaya dan Sula, 2006):

"pada dasarnya semua bentuk muamalah boleh dilakukan kecuali ada dalil yang mengharamkannya."

Seluruh proses dalam syariah marketing baik proses penciptaan, proses penawaran, maupun proses perubahan nilai, tidak boleh ada hal-hal yang bertentangan dengan akad prinsipprinsip muamalah yang islami. Sepanjang hal tersebut dapat dijamin dan pelanggaran-pelanggaran prinsip-prinsip muamalah Islami tidak terjadi dalam suatu transaksi atau dalam proses suatu bisnis, maka bentuk transaksi apa pun dalam pemasaran dapat dibolehkan. 
Allah SWT mengingatkan agar senantiasa menghindari perbuatan yang zalim dalam bisnis termasuk dalam proses penciptaan, penawaran dan proses perubahan nilai dalam pemasaran Allah SWT berfirman:

Daud berkata: "Sesungguhnya dia telah berbuat zalim kepadamu dengan memnita kambingmu itu untuk ditambahkan kepada kambingnya. Dan sesungguhnya kebanyakan dari orang-orang yang berserikat itu sebahagian mereka berbuat zalim kepada sebahagian yang lain, kecuali orang-orang yang beriman dan mengerjakan amal yang saleh: dan amat sedikitlah mereka ini". Dan Daud mengetahui bahwa Kami mengujinya: maka ia meminta ampun kepada Tuhannya lalu menyungkur sujud dan bertaubat. (QS. Shaad: 24)

Dalam Hadis, Rasulullah SAW bersabda:

"Allah berifirman: Aku adalah pihak ketiga dari dua orang yang bersyarikat selama salah satu pihak tidak mengkhianati pihak yang lain. Jika salah satu pihak telah berkhianat, aku keluar dari mereka." (HR Abu Daud dari Abu Hurairah)

Hadis ini secara terang menjelaskan pentingnya integritas, kejujuran, sikap amanah, dan profesionalisme, dalam bisnis Islami. Semuanya menjadi satu dalam good corporate governance. Ini juga gambaran betapa sikap saling percaya dalam bisnis ini menjadi sangat penting. Ketika salah satu di antaranya mengkhianati akad (perjanjian) yang telah disepakati, maka gugur pulalah kewajiban masing-masing secara syar'i (Kertajaya dan Sula, 2006). 


\section{Karakter Pemasaran Syariah}

Menurut Kertajaya dan Sula (2006) terdapat empat karakter pemasaran yang menjadi panduan bagi pemasar yaitu:

\section{Ketuhanan (Rabbaniyah/Religius).}

Merupakan salah satu ciri khas marketing syariah yang tidak dimiliki dalam pemasaran konvensional yang dikenal selama ini adalah sifatnya yang religius (dinniyah). Kondisi ini tercipta dari kesadaran akan nilai-nilai religius yang dipandang penting sehingga senantiasa mewarnai segala aktivitas dalam pemasaran. Ketuhanan (Rabbaniyah/Religius), ini adalah yang paling asil, paling sempurna, paling artinya seorang syariah marketer meyakini bahwa Allah SWT selalu dekat dan mengawasinya ketika dia sedang melaksanakan segala macam bentuk pertanggungjawaban darinya atas pelaksanaan syariat itu di hari kiamat.

Laki-laki yang tidak dilalaikan oleh perniagaan dan tidak (pula) oleh jual beli dari mengingati Allah, dan (dari) mendirikan sembahyang, dan (dari) membayarkan zakat. Mereka takut kepada suatu hari yang (di hati itu) hati dan penglihatan menjadi goncang. (QS. an-Nur: 37) 
Hal ini dapat membentuk sifat para pemasar menjadi yang paling adil, paling sempurna, paling mencegah dalam kerusakan, paling mampu mewujudkan kebenaran, memusnakan kebatilan dan menyebarluaskan kemaslahatan. Selain itu, pemasaran syariah haruslah memiliki nilai (value) yang lebih tinggi dan lebih baik, karena bisnis syariah adalah bisnis kepercayaan, bisnis berkadilan dan bisnis yang tidak mengandung tipu muslihat di dalamnya. Maka dalam pemasaran syariah seseorang harus senantiasa menjauhi hal-hal yang dilarang dalam syariar Islam, terutama hal-hal yang termasuk maysir, gharar, dan riba. untuk itu, suatu pekerjaan atau bisnis pasti didasari oleh niat dan tujuan yang ingin dicapai. Ketika perusahaan melakukan kegiatan pemasarannya, niat yang ada adalah mendapat keuntungan semaksimal mungkin. Namun, dalam prinsip marketing syariah, kegiatan tersebut harus dilandasi oleh semangat ibadah kepada Tuhan Sang Maha Pencipta, berusaha semaksimal mungkin dengan tujuan untuk mencapai kesejahteraan bersama, bukan kepentingan golongan apalagi untuk kepentingan diri sendiri (Kertajaya dan Sula, 2006)

\section{Menjunjung tinggi akhlak mulia (akhlaqiyyah).}

Karakterisitik yang kedua dari pemasaran syariah adalah sifatnya yang sangat mengedepankan akhlak (moral dan etika) dalam seluruh aspek kegiatan pemasaran dan menjadi pedoman dalam bisnis. Oleh 
karena itu, dalam pemasaran syariah tidak dibenarkan untuk menghalalkan segala cara demi mendapat keuntungan finansial sebesar mungkin. Rasulullah SAW pernah bersabda:

"Tidak ada sesuatu lebih berat dalam timbangan seorang mukmin di hari kiamat, selain daripada keindahan akhlak. Dan Allah SWT benci kepada yang keji mulut dan kelakuan." (HR. Tirmidzi, dalam At Tirmidzi VI, 1965: 140)

Pemasaran syariah merupakan konsep pemasaran yang sangat mengedepankan nilai-nilai moral dan etika adalah nilai yang bersifat universal yang diajarkan oleh semua agama. Semakin beretika seorang dalam berbisnis, maka dengan sendirinya dia akan menemui kesuksesan. Karena itu, sudah sepatutnya akhlak dapat menjadi panduan bagi seorang marketer untuk selalu memelihara nilai-nilai moral dan etika dalam setiap tutur kata, perilaku dan keputusan-keputusannya.

\section{Realistis (waqi'iyah).}

Mewaspadai keadaan pasar yang selalu berubah (waqi'iyah/realistis), karena pemasaran syariah merupakan konsep pemasaran yang profesional dan fleksibel, sebagaimana keluasan dan keluwesan syariah islamiyah yang melandasinya. Syariah marketing bukanlah konsep yang eksklusif, fanatis, 
anti modernitas dan kaku. Akan tetapi, syariah marketing adalah konsep pemasaran yang fleksibel, sebagaimana keluasan dan keluwesan syariah islam yang melandasinya. Fleksibel berarti tidak kaku dan eksklusif dalam bersikap, berpenampilan dan bergaul. Namun tetap harus bekerja dengan profesional serta mengedepankan nilai-nilai religius, kesalehan, aspek moral, dan kejujuran dalam segala aktivitas. Fleksibilitas atau kelonggaran sengaja diberikan oleh Allah SWT agar penerapan syariah senantiasa realistis dan dapat mengikuti perkembangan zaman.

\section{Humanistis (al-insaniyyah).}

Salah satu keistimewaan dan pemasaran syariah adalah sifatnya yang humanistis universal. Pengertian humanistis adalah bahwa syariah diciptakan untuk manusia agae derajatnya terangkat, sifat kemanusaiaannya terjaga dan terpelihara serta sifatsifat kehewanannya dapat terkekang dengan panduan syariah. Syariah islam yang bersifat humanistis (insaniyyah), yang diciptakan untuk manusia sesuai dengan kapasitasnya tanpa membedakan ras, warna kulit, kebangsaan maupun status. Dengan memiliki nilai-nilai humanistis, manusia dapat terkontrol dan seimbang (tawazun), bukan menjadi manusia yang bahagia menghalalkan segala cara untuk maraih keuntungan sebesar mungkin, bukan pula menjadi manusia yang bahagia di atas penderitaan orang lain. Hal inilah yang membuat syariah memiliki sifat 
universal sehingga menjadi syariah humanistis universal.

\section{Etika Dalam Pemasaran Syariah}

Menurut Kertajaya dan Sula (2006) bahwa dalam Islam terdapat pula sembilan macam etika yang harus dimiliki seorang tenaga pemasaran. Kesembilan etika tersebut adalah:

1. Memiliki kepribadian spiritual (takwa).

Seorang Muslim diperintahkan untuk selalu mengingat Allah SWT bahkan dalam suasana mereka sedang sibuk dalam aktivitas mereka, misalnya ia harus menghentikan aktivitas bisnisnya saat datang panggilan shalat, sebagaimana firman Allah SWT:

Hai orang-orang beriman, apabila diseru untuk menunaikan salat Jumat, makabersegeralah kamu kepada mengingat Allah dan tinggalkanlah jual beli. Yang demikian itu lebih baik bagimu jika kamu mengetahui. Apabila telah ditunaikan salat, maka bertebaranlah kamu di muka bumi: dan carilah karunia Allah dan ingatlah Allah banyak-banyak supaya kamu beruntung. (QS. al-Jumu'ah: 9-10).

Dengan mengingat Allah SWT maka syariah marketer akan terbebas dari sifat-sifat kecurangan, kebohongan, kelicikan, dan penipuan dalam melakukan pemasaran. 


\section{Berkepribadian baik dan simpatik (shiddiq).}

Al-Qur'an mengajarkan untuk senantiasa berwajah manis, berperilaku baik dan simpatik. Allah SWT berfirman:

Janganlah sekali-kali kamu menunjukkan pandanganmu kepada kenikmatan hidup yang telah Kami berikan kepada beberapa golongan di antara mereka (orangorang kafir itu) dan janganlah kamu bersedih hati terhadap mereka dan serendah dirilah kamu terhadap orang-orang yang beriman. (QS. al-Hijr: 88)

Begitu pula bagi seorang Muslim yang hendak menjual barang dengannya harus dengan senang hari, ikhlas dan memberikan kesan baik terhadap pembeli, seperti yang di ungkapkan dalam sebuah Hadis:

"Allah mengasihi orang yang bermurah hati waktu menjual, waktu membeli, dan waktu menagih piutang." (HR. Bukhari dalam Mukhtashor Shahih al-Bukhari: 280).

\section{Berlaku adil dalam berbisnis ( $a l-a d l)$}

Berbisnis secara adil adalah hukumannya wajib. Allah SWT mencintai orang-orang yang berbuat adil dan membenci orang-orang yang berbuat zalim, bahkan melaknat mereka, sebagaimana dengan firman-Nya:

Dan siapakah yang lebih zalim daripada orang yang membuat-buat dusta terhadap Allah? Mereka itu akan dihadapkan kepada Tuhan mereka, dan para saksi akan berkata: "orang-orang inilah yang telah berdusta 
terhadap Tuhan mereka". Ingatlah, kutukan Allah (ditimpakan) atas orang-orang yang zalim. (QS. Hud: 18).

4. Melayani dengan senyum dan rendah hati (khidmah). Sikap melayani merupakan sikap utama dari seorang pemasar. Pelayanan merupakan faktor yang paling penting dalam suatu bisnis.

"sesungguhnya rendah hari adalah salah satu ciri orang yang bertakwa, dengannya, orang yang bertakwa mencapai derajat kemuliaan."

\section{Selalu menepati janji dan tidak curang (tathfif).}

Seorang syariah markerter harus dapat menjaga amanah yang diberikan kepadanya sebagai wakil dari perusahaan dalam memasarkan dan mempromosikan produk kepada pelanggan. Allah SWT berfirman tentang sikap amanah: Jika kamu dalam perjalanan (dan bermuamalah tidak secara tunai) sedang kamu tidak memperoleh seorang penulis, maka hendaklah ada barang tanggungan yang dipegang (oleh yang berpiutang). Akan tetapi jika sebagian kamu memercayai sebagian niatnya (hutangnya) dan hendaklah ia bertakwa kepada Allah Tuhannya: dan janganlah kamu (para saksi) menyembunyikan persaksian. Dan barangsiapa yang menyembunyikannya, maka sesungguh ia adalah orang yang berdosa harinya, dan Allah Maha Mengetahui apa yang kamu kerjakan. (QS. al-Baqarah: 283) 
Sikap sebaliknya adalah sikap curang (tathfif), sikap ini dapat muncul dalam menentukan harga, takaran, ukuran, dan timbangan. Etika Rasulullah dalam membangun citra dagangnya salah satunya adalah tidak membohongi pelanggan, baik menyangkut besaran (kuantitas) maupun kualitas. Allah SWT berfirman:

Sempurnakanlah takaran dan janganlah kamu termasuk orang-orang yang merugikan. Dan timbanglah dengan timbangan yang lurus. Dan janganlah kamu merugikan manusia pada hak-haknya dan janganlah kamu merajalela di muka bumi dengan membuat kerusakan. (QS. as-Syu'ara: 181-183)

Rasulullah SAW bersabda:

"apabila dilakukan penjualan maka katakanlah tidak ada penipuan." (Muttafaq'alaih, dalam al Bukhari III: 137)

\section{Jujur dan terpercaya (amanah).}

Diantara akhlak yang harus menghiasi pelayanan dalam setiap gerak-geriknya adalah kejujuran. Terkadang sifat jujur dianggap mudah untuk dilaksanakan bagi orangorang awam manakala tidak dihadapkan pada ujian yang berat atau tidak dihadapkan pada godaan duniawi. Di sinilah Islam menjelaskan bahwa kejujuran yang hakiki itu terletak pada muamalah mereka, Rasulullah SAW bersabda:

Dari Abu Sa'id dari Nabi SAW bersabda: "pedagang yang jujur dan terpercaya akan bersama para nabi, para shiddiqin, orang-orang yang meninggak syahid dalam 
peperangan dan orang-orang yang saleh." (HR. Tirmidzi dalam Maushu'ah al Hadis al Syarif Versi 2, 1991-1997).

\section{Tidak suka berburuk sangka (su'uzhon).}

Saling menghormati satu sama lain merupakan ajaran Rasulullah SAW yang harus diimplementasikan dalam perilaku bisnis modern. Tidak boleh pengusaha menjelekkan pengusaha yang lain. Allah SWT berfirman:

Hai orang-orang yang beriman, jauhilah kebanyakan purbasangka (kecurigaan), karena sebagian dari purbasangka itu dosa. Dan janganlah mencari-cari keburukan orang dan janganlah menggunjingkan satu sama lain. Adakah seorang di antara kamu yang suka memakan daging saudaranya yang sudah mati? Maka tentulah kamu merasa jijik kepadanya. Dan bertakwalah kepada Allah. Sesungguh Allah Maha Penerima Taubat lagi Maha Penyayang. (QS al-Hujuraat: 12)

\section{Tidak suka menjelek-jelekkan (ghibah).}

Biasanya seorang pemasar senang apabila telah mengetahui kelemahan atau kejelekan lawan bisnisnya, dan biasanya kelemahan dan kejelekkan ini dijadikan senjata untuk memenangkan pertarungan di pasar dengan cara menjelk-jelekkan (karena faktanya benar) atau memfitnah (karena faktanya tidak benar). Perbuatan tersebut disebut ghibah. Firman Allah SWT: 
Sesungguhnya orang-orang yang ingin agar (berita) perbuatan yang amat keji itu tersiar di kalangan orangorang yang beriman, bagi mereka azab yang pedih di dunia dan di akhirat. Dan Allah mengetahui, sedang kamu tidak mengetahui. (QS. an-Nur: 19).

\section{Tidak melakukan suap (risywah).}

Dalam syariah menyuap hukumannya haram dan menyuap termasuk dalam kategori makan harta orang lain dengan cara batil. Firman Allah SWT dalam alBaqarah (2): 188:

Dan janganlah sebahagian kamu memakan harta sebahagian yang lain di antara kamu dengan jalan yang bathil dan (janganlah) kamu membawa (urusan) harta itu kepada hakim, supaya kamu dapat memakan sebahagian daripada harta benda yang orang lain itu dengan (jalan berbuat) dosa, padahal kamu mengetahui.

Rasulullah SAW bersabda:

"Rasulullah SAW melaknat penyuap, penerima suap, dan yang menjadi perantaranya." (HR. Ahmad dan Hakim, Ahmad bin Hanbal II: 164)

Selain itu ada lima hal sifat yang harus dimiliki oleh seorang pemasar, yaitu:

\section{Benar dan jujur (shiddiq).}

Seorang pemasar haruslah memiliki sifat benar dan jujur (shiddiq) dalam menjiwai seluruh perilakunya dalam 
melakukan pemasaran, yang berhubungan dengan pelanggaran, dalam bertransaksi dengan nasabah, dan dalam membuat perjanjian dengan mitra bisnisnya.

\section{Terpercaya dan kredibel (amanah).}

Seorang pemasar haruslah mempunyai sifat dapat dipercaya, bertanggung jawab, dan kredibel juga untuk memenuhi sesuatu yang sesuai dengan ketentuan, juga dalam melakukan pemasaran, yang terkait dengan pelanggan, dalam bertransaksi dengan nasabah dan membuat perjanjian dengan pelanggannya.

\section{Cerdas (fathanah).}

Artinya intelektual, kecerdikan, atau kebijaksanaan. Pemasar yang fathanah adalah pemasar yang memahami, mengerti dan menghayati secara mendalam segala hal yang menjadi tugas dan kewajibannya.

\section{Komunikatif (tabligh).}

Komunikatif dan argumentarif, pemasar dengan sifat ini akan menyampaikannya dengan benar, tutur kata yang tepat. Berbicara dengan orang lain dengan sesuatu yang mudah dipahaminya, berdiskusi dan melakukan presentasi bisnis dengan bahasa yang mudah dipahami sehingga orang tersebut mudah memahami pesan bisnis yang ingin kita sampaikan.

\section{Konsisten (istiqomah)}


Seorang pemasar syariah dalam praktik pemasarannya haruslah selalu istiqomah dalam penerapan aturan Prinsip Pemasaran Syariah

Sesuai dengan Hermawan dan Syakir (2006) yang menguraikan beberapa prinsip pemasaran syariah diantaranya:

1. Lanskap Bisnis Syariah

a. Information Technology Allows Us to be Transparent (Change)

Perubahan adalah sesuatu hal yang pasti akan terjadi. Kekuatan perubahan terdiri dari lima unsur, yaitu perubahan teknologi, perubahan ekonomi, perubahan politik, perubahan sosial-kultural, dan perubahan pasar. Perubahan yang paling utama adalah perubahan teknologi, karena teknologi akan memberi efek yang lebih luas terhadap segala aspek yang nantinya akan juga mengalami perubahan. Perkembangan teknologi memberi pengaruh yang besar terhadap perusahaan syariah. Selain sebagai penunjang operasional dan standar layanan, teknologi juga menunjukkan kesungguhan dalam melaksanakan prinsip syariah marketing, serta untuk kemudahan konsumen untuk mendapatkan informasi dan melakukan komunikasi menjadi kunci bagi perusahaan untuk menunjukkan kejujuran secara transparan.

b. Be Respectful to Your Competitors (Competitor) 
Globalisasi dan perubahan teknologi menciptakan persaingan usaha yang ketat. Pasar semakin kompleks, terbuka dan modern. Dalam menghadapi persaingan maka dibutuhkan motivasi dan keterbukaan diri dengan berupaya menciptakan win-win solution antara perusahaan dan pesaingnya. Informasi yang mudah didapat menjadikan perusahaan dimungkinkan untuk mengakses info pesaing dan persaingan. Berkompetisi secara jujur dan adil maka akan memberikan pandangan positif dari masyarakat terhadap sebuah perusahaan. Sebagai perusahaan syariah komitmen kejujuran, sikap adil, maslahat senantiasa menjadi standar dalam bersaing secara sehat meskipun pelaku pasar sering terjadi perilaku yang kurang bermoral.

c. The Emergence of Customers Global Paradox (Customer)

Pengaruh inovasi teknologi mendasari terjadinya perubahan sosial budaya. Lahirnya revolusi dalam bidang teknologi informasi dan telekomunikasi mengubah cara pandang dan perilaku masyarakat, contoh bahwa kehadiran internet telah membawa perubahan pada segala sektor kehidupan manusia. Setiap produk dan servis sebenarnya ditujukan untuk kepentingan masyarakat yang membeli produk atau jasa seharusnya harus diberikan perhatian secara maksimal. Bagi perusahaan syariah globalisasi membawa banyak manfaat dan peluang menjadi sarana untuk lebih baik. Pengaruh informasi dan teknologi ibarat pisau bermata dua 
tergantung cara dan sikap kita dalam mengambil manfaat di dalamnya.

Di era globalisasi seperti sekarang, masyarakat menjalani kehidupannya secara paradoks. Sebagai contoh, internet telah memaksimalkan fungsinya memberikan informasi global secara massal. Namun, dilain pihak, terlalu banyak informasi yang ada membuat masyarakat menjadi sulit memilih informasi yang benar atau mana informasi yang dibutuhkan. Paradoks yang terjadi mengharuskan untuk fokus terhadap apa yang penting dalam hidup dan aktivitas sehari-hari. Jika diamati di tengah arus globalisasi dan modernisasi, ada kerinduan manusia untuk kembali ke kehidupan yang penuh kedamaian dan ketentraman. Kehidupan yang serba tidak menentu membuat manusia kembali ke akar fundamental agamanya.

d. Develop a Spiritual Based Organization (Company)

Dalam era globalisasi sudah saatnya perusahaan merujuk kembali prinsip-prinsip perusahaan tersebut sehingga dengan menerapkan spiritual based organization-nya, perusahaan dengan segenap visi misinya akan selalu berusaha untuk menjadikan dunia sebagai tempat yang lebih baik dan mengedepankan kerendahan hati dan kejujuran serta akan selalu konsisten dengan prinsip-prinsipnya.

2. Syariah Marketing Strategy 
Untuk memenangkan mind-share, dapat dilakukan pemetaan pasar, keunggulan kompetitif, dan situasi persaingan. Dari pemetaan potensi pasar sebelumnya, dapat dilihat bahwa pasar rasional atau pasar mengambang merupakan pasar yang sangat besar. Para pebisnis harus dapat membidik pasar rasional yang sangat potensional tersebut. Setelah itu, mereka perlu melakukan positioning sebagai perusahaan yang mampu meraih mind-share. Berikut ini akan diuraikan perinciannya.

a. View Market Universally (Segmentation)

Segmentasi adalah seni mengidentifikasikan serta memanfaatkan peluang-peluang yang muncul di pasar. Dalam melihat pasar, perusahaan harus kreatif dan inovatid menyikapi perkembangan yang terjadi, karena segmentasi langkah awal yang menentukan keseluruhan aktivitas perusahaan.

Syariah Islam adalah komprehensif dan universal. Adapun yang dimaksud dengan komprehensif adalah bahwa syariah merangkum seluruh aspek kehidupan, baik ritual (ibadah) melainkan juga aspek sosial (muamalah). Ibadah diperlukan untuk menjaga ketaatan dan keharmonisan hubungan manusia dengan penciptanya. Adapun aspek sosial diturunkan menjadi aturan dalam kehidupan bermasyarakat. Adapun universal bermakna bahwa syariah dapat diterapkan setiap waktu dan tempat oleh setiap manusia. Kaitannya dengan kondisi pasar (market), prinsip syariah islam hendaknya digunakan dan 
dapat digunakan tidak hanya oleh masyarakat Muslim universal agama yang rahmatan lil'alamin.

b. Target Customer's Heart and Soul (Targeting)

Targeting adalah strategi mengalokasikan sumber daya perusahaan secara efektif, karena sumber daya yang dimiliki terbatas. Dengan menentukan target yang akan dibidik usaha kita akan lebih terarah. Olehnya, perusahaan harus membidik pasar yang akan dimasuki sesuai daya saing yang dimiliki (competitive advantage).

Menurut Warren dalam bukunya, Global Marketing Management, kriteria target market adalah market size dengan potential competition, dan compability dengan feasibility. Tentunya untuk bersaing perusahaan harus memiliki keunggulan komparatif dan kompetitif sesuai resources yang dimiliki. Ada tiga hal yang dibutuhkan dalam segmentasi pasar, yaitu:

1) Segmen pasar yang dipilih cukup besar dan menguntungkan (market size).

2) Strategy targeting harus didasarkan pada keunggulan daya saing perusahaan (competitive advantage).

3) Situasi persaingan (competitive situation). Olehnya, perusahaan syariah harus mampu membidik hati dan jiwa konsumennya. Baik yang jangka lama (long-term) maupun yang bersifat singkat (short-term). 
c. Build a Belief System (Positioning)

Yaitu strategi untuk merebut posisi di benak konsumen, sehingga strategi ini terkait bagaimana membangun kepercayaan, keyakinan, dan kompetensi bagi pelanggan. Positioning ini menetapkan bagaimana identitas produk atau perusahaan tertanam dibenak konsumen yang mempunyai kesesuaian dengan kompetensi yang dimiliki perusahaan untuk mendapatkan kepercayaan, kredibilitas, dan pengakuan dari konsumen. Positioning harus sustainable terhadap perubahanperubahan yang terjadi di pasar yang harus terus dikomunikasikan secara konsisten dan tidak berubahubah. Perusahaan syariah harus membangun positioning yang kuat dan positif sangatlah penting, citra syariah harus bisa dipertahankan dengan menawarkan valuevalue yang sesuai prinsip syariah.

Konsumen memegang peranan kunci untuk pembelian dan pemakaian produk usaha. Tersedianya berbagai pilihan diserta kelebihan dan kekurangan masing-masing produk membuat konsumen selalu membandingkan produk perusahaan yang satu dengan yang lain. Untuk itulah, positioning diperlukan agar citra terhadap produk atau perusahaan dapat terbentuk sesuai dengan niat dan tujuan perusahaan. Dalam positioning perusahaan menawarkan value yang akan diterima oleh konsumen. Yang mana value tersebut harus sesuai dengan prinsip-prinsip syariah dan mampu menunjukkan 
bahwa perusahaan tersebut lebih baik dari pada perusahaan non-syariah.

3. Syariah Marketing Tactic

Untuk memenangkan market-share. Ketika positioning pebisnis syariah di benak pasar rasional telah kuat, mereka harus melakukan diferensiasi yang mencakup apa yang ditawarkan (content), bagaimana menawarkan (context) dan apa infrastruktur dalam menawarkannya. Langkah selanjutnya para marketer perlu menerapkan diferensiasi secara kreatif dan inovatod dengan menggunakan marketing mix (price, product, place, and promotion). Hal lain yang juga perlu dipersiapkan adalah bagaimana pebisnis melakukan selling dalam meningkatkan hubungan dengan pelanggan sehingga mampu menghasilkan keuntungan finansial., berikut perinciannya:

a. Differ Yourself with a Good Pacpage of Content and Context (Differentiation)

Diferensiasi adalah tindakan merancang seperangkat perbedaan yang bermakna dalam tawaran perusahaan. Diferensiasi ini bisa berupa content (what of offer) dan context (how to offer) dan infrastruktur (capability to offer). Content adalah dimensi diferensiasi yang merujuk pada value yang ditawarkan kepada pelanggan anda. Context merupakan dimensi yang merujuk pada cara anda menawarkan produk. Adapun infrastructure merujuk pada teknologi, SDM (people) dan fasilitas (facility) yang 
digunakan untuk menciptakan diferensiasi content dan context.

b. Be Honest with Your 4 Ps (Marketing Mix)

Marketing mix dikenal dengan 4P dengan elemenelemennya adalah product (produk), price (harga), place (tempat/distribusi), dan promotion (promosi). Product dan price adalah komponen dari tawaran (offer), sedangkan place dan promotion adalah kompenen dari akses (access). Marketing mix dimaksudkan bagaimana mengintegrasikan tawaran dari perusahaan (company of offer) dengan akses yang tersedia (company access). Proses pengintegrasian ini menjadi kunci suksesnya usaha pemasaran dari perusahaan. Model ini disebut juga dengan creation tactic karena marketing mix haruslah berdasarkan penciptaan diferensiasi dari sisi content, context, dan infrastructure. Bagi perusahaan syariah, untuk komponen tawaran (offer), prisuk dan harga haruslah didasari dengan nilai kejujuran dan keadilan sesuai dengan prinsip-prinsip syariah. Kualitas produk yang diberikan harus sesuai dengan yang ditawarkan. Jadi dilarang perusahaan menyembunyikan kecacatan dari produk yang ditawarkan. Dalam menentukan harga pun, perusahaan harus mengutamakan nilai keadilan. Jika kualitas produknya bagus harganya bisa tinggi, sebaliknya, jika produknya tidak berkualitas maka harga harus disesuaikan. 
Komponen akses berupa promosi bagi perusahaan syariah haruslah menggambarkan secara real apa yang ditawarkan dari produk-produk atau servis perusahaan tersebut. Promosi tidak boleh terlalu menampilkan imajinasi yang terlalu tinggi bagi konsumennya karena ini termasuk penipuan dan kebohongan. Dalam menentukan places atau salurab distribusi, perusahaan harus mengutamakan tempat-tempat yang sesuai dengan target market sehingga dapat efektif dan efisien. Proses integrasi terhadap offer dan access harus didasari oleh prinsipprinsip keadilan dan kejujuran.

c. Practice a Relationship-Based Selling (Selling)

Selling adalah penyerahan barang atau jasa dari penjual kepada pembeli dengan harga yang disepakati atas dasar sukarela. Pengertian secara luas bahwa selling adalah memaksimalkan kegiatan penjualan sehingga dapat menciptakan situasi yang win-win solution bagi si penjual dan si pembeli. Bagi perusahaan syariah harus menjadikan konsumen sebagai teman dengan sikap tolong-menolong dan kejujuran sebagai teman dengan sikap tolong-menolong dan kejujuran sebagai landasan utama serta membangun keharmonisan dengan konsumen.

\section{Syariah Marketing Value}

Untuk memenangkan heart-share (kecintaan pelanggan terhadap produk), semua strategi dan taktik yang sudah 
dirancang akan berjalan optimal bila disertai dengan peningkatan value dari produk atau jasa yang dijual. Peningkatan value disini berarti bagaimana kita mampu membangun brand yang kuat, memberikan servis yang membuat pelanggan loyal, dan mampu menjalankan proses yang sesuai dengan kepuasan pelanggan. Dalam syariah marketing value, brand merupakan nama baik yang menjadi identitas seseorang atau perusahaan. Contohnya Nabi Muhammad SAW yang terekam kuat di pikiran semua orang bahwa beliau adalah seorang al-amin. Brand itu menjadikan Nabi Muhammad lebih mudah untuk mengomunikasikan produknya, karena semua orang telah memercayai semua kata-katanya.

a. Use a Spritual Brand (Brand)

Brand atau merek adalah suatu identitas terhadap produk atau jasa perusahaan. Brand mencerminkan nilai (value) yang diberikan kepada konsumen. Jika perusahaan mempunyai Total Get yang lebih tinggi dibandingkan Total Give, brand yang dimiliki mempunyai nilai ekuitas yang kuat. Selaun itu positioning dan differentiation yang telah terbentuk, brand akan menambah value bagi produk dan jasa yang ditawarkan. Brand yang baik adalah brand yang mempunyai karakter yang kuat dan bagi perusahaan atau produk yang menerapkan syariah marketing atau prinsip-prinsip syariah, yaitu brand yang tidak mengandung unsur judi, penipuan, riba, dan tidak mengandung unsur kezaliman dan tidak membahayakan pihak sendiri ataupun pihak orang lain. 
b. Service Should Have the Ability to Transform (Service)

Untuk menjadi perusahaan yang besar dan suistanable, perusahaan berbasis syariah marketing harus memerhatikan service yang ditawarkan untuk menjaga kepuasa pelanggannya. Dalam melakukan pelayanan seseorang memerhatikan sikap, pembicaraan yang baik, bahasa tubuh, bersifat simpatik, lembut, sopan, hormat dan penuh kasih sayang.

c. Practice a Realible Business Process (Proses)

Proses mencerminkan quality, cost, dan delivery (QCD). Kualitas suatu produk ataupun servis tergambar dari proses yang baik, dari proses produksi sampai delivery kepada konsumen secara tepat dan dengan biaya yang efektif dan efisien. Proses dalam konteks kualitas adalah bagaimana menciptakan proses yang mempunyai nilai lebih untuk konsumen. Proses dalam konteks cost adalah bagaimana menciptakan proses yang efisien yang tidak membutuhkan biaya yang banyak, tetapi kualitas terjamin. Adapun proses dalam konteks delivery adalah bagaimana proses pengiriman atau penyampaian produk atau servis yang ditawarkan perusahaan kepada konsumen.

\section{Syariah Marketing Scorecard}

Untuk menciptakan keseimbangan value kepada para stakeholder (pemangku kepentingan). Tiga stakeholder utama dari suatu perusahaan adalah people, customers, dan 
shareholder. Ketiga stakeholder tersebut sangat penting karena mereka adalah orang-orang yang sangat berperan dalam menjalankan suatu usaha. Di dalam pasar komersial (commercial market), perusahaan harus bisa mengakuisisi dan meretensi pelanggannya. Didalam pasar kompetensi (competency market), perusahaan harus dapat memilih dan mempertahankan orang-orang yang tepat. Adapun di dalam pasar modal (capital market), perusahaan harus bisa mendapatkan dan menjaga para pemegang saham yang tepat. Untuk menjaga keseimbangan ini, perusahaan harus bisa menciptakan value yang unggul bagi ketiga stakeholder utama tersebut dengan ukuran dan bobot yang sama.

a. Create Balanced Value to Your Stakeholders (Scorecard)

Prinsip dalam syariah marketing adalah menciptakan value bagi stakeholder-nya. Tiga stakeholder dari suati perusahaan adalah people, customers, dan shareholder, karena ketiganya sangat berperan dalam menjalankan usaha. Hubungan horizontal dan hubungan vertical harus dijaga dengan baik demi menjaga hubungan yang harmonis dengan stakeholder dan yang utama adalah hubungan dengan Sang Pencipta.

b. Create a Noble Cause (Inspiration)

Perusahaan hendaknya memiliki impian (dream) untuk mencapai kesuksesan, karena impian ini akan mengantar seseorang dalam mewujudkan tujuan perusahaannya. Olehnya itu perusahaan berbasis syariah 
marketing, penentuan visi dan misi tidak bisa terlepas dari makna syariah itu sendiri serta tujuan akhir yang ingin dicapai. Tujuan akhir ini harus bersifat mulia, lebih dari sekedar finansial semata.

c. Develop an Ethical Corporate Culture (Culture)

Perusahaan yang berbasis syariah hendaknya mengembangkan budaya perusahaan sesuai syariah. Seluruh pola, perilaku, sikap dan aturan-aturan senantiasa tidak boleh terlepas dari basis syariah. Budaya dapat kita implementasikan seperti budaya salam, murah hati, ramah, melayani, disiplin, cara berbusana, teratur dan tertib, dan lingkungan kerja yang tenang, bersih dan indah.

Pada perusahaan berbasis syariah, budaya perusahaan yang berkembang dalam perusahaannya sudah pasti berbeda dengan perusahaan konvensional. Budaya perusahaan menggambarkan jati diri perusahaan tersebut: who we are dan how we do the business. Hal ini tercermin dari nilai-nilai yang dianut oleh setiap individu di perusahaan dan perilakunya ketika menjalankan bisnisnya. Budaya perusahaan yang sehat adalah budaya yang diekspresikan oleh setiap karyawannya dengan hati terbuka dan sesuai dengan nilai-nilai etika.

d. Measurement Must be Clear and Transparent (Institution)

artinya bagaimana membangun organisasi perusahaan sesuai dengan prinsip-prinsip syariah. Segala 
kebutuhan stakeholders secara mendasar dipenuhi dengan baik pada sistem yang benar. Ketelitian, transparansi, ketepatan dan kecepatan dan pelayanan yang professional semuanya merupakan hal yang menjadi standar organisasi.

\section{Syariah Marketing Enterprise}

Untuk menciptakan sebuah inspirasi (inspiration). Setiap perusahaan, layaknya manusia, haruslah memiliki impian (dream). Inspirasi tentang impian yang hendak dicapai inilah yang akan membimbing manusia, dan juga perusahaan, sepanjang perjalanannya. Sebuah perusahaan harus mampu menggabungkan antara idealisme dan pragmatisme. Perusahaan harus mampu idealistic dan sekaligus pragmatis, dan mampu mengimplementasikan kedua hal ini sekaligus dan secara simultan, tanpa adanya trade-off.

Suatu model pemasaran di mana perusahaan mampu bertahan dan sukses tidak hanya pada saat ini tetapi juga di masa mendatang. Bahwa perusahaan mengalami fase sebagaimana fase kehidupan manusia, yang harus mempertahankan diri pada saat terjadi krisis dan perubahan situasi dan kondisi. Jika perusahaan ingin tetap hidup, pemimpin perusahaan harus melakukan tindakan creative destruction sebelum krisis menghadang, sehingga perusahaan mulai kembali siklus hidupnya. Perusahaan yang baik adalah perusahaan yang bisa mempertahankan keadaannya secara kontinu agar dapat bertahan hidup dalam pasar yang terus berubah (Hurst, 1995). 
Dalam sustainable marketing enterprise, konsep pemasaran di sini tidaklah berarti pemasaran sebagai sebuah fungsi atau departemen dalam perusahaan, tetapi bagaimana kita bisa melihat pasar secara kreatif dan inovatif. Pemasaran bukanlah hanya seperti anggapan orang yaitu studi untuk menjual atau seperti yang dipahami beberapa kalangan hanyalah marketing mix semata. Namun pengertian terhadap pemasaran itu sendiri cakupannya lebih luas.

Suatu pekerjaan pasti didasari oleh niat dan tujuan yang ingin dicapai. Ketika perusahaan melakukan kegiatan pemasarannya niat yang ada adalah mendapatkan keuntungan sebanyak mungkin, namun dalam prinsip syariah, kegiatan pemasaran ini harus dilandasi oleh semangat beribadah kepada Allah SWT Sang Maha Pencipta dan berusaha sebisa mungkin dengan tujuan untuk kesejahteraan bersama bukan untuk kepentingan golongan apalagi kepentingan sendiri.

Maka untuk menjadi perusahaan berbasis syariah, budaya perusahaan tentulah harus berdasarkan nilai-nilai islami. Institusinya pun harus mengimplementasikan prinsip-prinsip syariah. Nilai-nilai islam inilah sebagai pemegang peranan penting untuk membentuk kepribadian suatu perusahaan (Kertajaya dan Sula, 2006).

\section{F. PERBANDINGAN PEMASARAN SYARIAH DAN PEMASARAN KONVENSIONAL}

Berikut ini akan dipaparkan perbandingan antara pemasaran syariah dan pemasaran konvensional (Arif, 2010). 
1. Konsep dan Filosofi Dasar

Pemasaran konvensional merupakan pemasaran yang bebas nilai dan tidak mendasarkan pada nilai-nilai ilahiah dalam segala aktivitas pemasarannya. Pemasar hanya lebih fokus pada pencapaian target penjualan yang telah ditetapkan perusahaan. Dalam pemasaran syariah seorang pemasar harus merasakan bahwasanya setiap aktivitas pemasarannya ia selalu diawasi oleh Allah SWT, sehingga sangat berhati-hati dalam menjaga aktivitas pemasarannya.

2. Etika Pemasar

Pemasar syariah sangat memegang teguh etika dalam melakukan pemasaran kepada calon konsumennya. Sangat menghindari kebohongan, berlebihan dalam promosi, menjaga kejujuran dan janji. Dibandingkan pemasaran konvensional cenderung bebas nilai sehingga seorang pemasar bebas menggunakan cara-cara meskipun bertentangan dengan syariah.

3. Pendekatan dengan Konsumen

Konsumen dalam pemasaran syariah diletakkan sebagai mitra yang sejajar. Perusahaan tidak menjadikan konsumen sebagai "sapi perah" untuk membeli produknya. Olehnya tidak boleh melakukan aktivitas pemasaran yang merugikan konsumen. Selalu berupaya menciptakan nilai produk yang positif dan umpan balik dari konsumennya. Sebaliknya pada pemasaran konvensional cenderug konsumen diletakkan sebagai objek untuk mencapai target 
penjualan semata. Konsumen kadang dirugikan dengan janji yang berbeda dengan realitas.

\section{Cara Pandang Terhadap Pesaing}

Dalam pemasaran syariah setiap perusahan dapat bersaing secara sehat dan masing-masing mempunyai peluang untuk berkembang dengan baik tanpa menjatuhkan pesaingnya. Pesaing merupakan mitra yang turut salam menyukseskan implementasi ekonomi syariah. Hal berbeda pada pemasaran konvensional cenderung menganggap pesaing sebagai pihak lawan yang harus dimatikan karena dapat menghambat laju perusahaan.

5. Budaya Kerja

Budaya kerja yang harus diaplikasikan adalah bagaimana budaya kerja yang dituntunkan oleh Rasulullah SAW yaitu memiliki sifat kejujuran (shiddiq), cerdas atau kompeten (fathonah), bertanggung jawab (amanah) dan mampu menyebarluaskan dan mengomunikasikan aktivitas kerja yang baik (tabligh).

\section{HAKIKAT FATHONAH, AMANAH, SHIDDIQ, TABLIGH DALAM PEMASARAN}

Salah satu rukun iman yang wajib diyakini oleh umat Muslim adalah percaya akan keberadaan Nabi dan Rasul. Sejak Allah SWT menciptakan Nabi Adam a.s. dan mengangkatnya menjadi Nabi dan Rasul pertama, muncul para Nabi dan Rasul lain yang diangkat-Nya untuk menjadi pengemban risalahm 
menyerukan ajaran-ajaran dan petunjuk-Nya kepada manusia di bumi sekaligus menjadi teladan bagi manusia lainnya.

Allah SWT tidak menjelaskan secara perinci mengenai jumlah Nabi dan Rasul yang diutus-Nya sejak Nabi Adam a.s. hingga Nabi Muhammad SAW. Namun terdapat riwayat Ahmad yang disampaikan Ibnu Hibban, diterimanya dari Abu Dzar alGhifary, dikatakan bahwa Rasulullah menyebutkan jumlah para Nabi sekitar 124.000 dan jumlah para Rasul adalah 313. Adapun jumlah Nabi dan Rasul yang wajib diketahui adalah 25.

Allah SWT menerangkan dalam Al-Qur'an kisah dari sebagian Nabi dan Rasul dengan karakter dan mukjizatnya masing-masing. Meskipun para Nabi dan Rasul tersebut memiliki karakter yang berbeda-beda, menerima kitab dan shahifah sendiri-sendiri serta hidup dalam kurun waktu yang sangat berjauhan, akan tetapi dalam hal sifat kepribadaian sejatinya mereka memiliki kesamaan satu sama lain. Sifat utama dan menonjol di antara kedua puluh lima Nabi yang wajib diketahui itu antara lain, fathonah (cerdas), amanah (bertanggung jawab), shiddiq (jujur), dan tabligh (menyampaikan).

Keempat sifat ini wajib dimiliki oleh para Nabi dan Rasul, sebab dengan keempat sifat ini mereka mampu mengemban amanah untuk menyampaikan risalah kepada umat manusia. Orang islam yang sudah dewasa (baligh) diwajibkan untuk mengetahui empat saifat ini, selain diwajibkan pula mengetahui sifat-sifat wajib bagi Allag SWT. Dengan mengetahui sifat wajib bagi Nabi dan Rasul, manusia dapat meneladani kepribadian mereka sebagai utusan Allah SWT. Tidak cukup hanya 
mengetahui, yang terpenting adalah memahami hakikat dari keempat sifat tersebut, memahami maksudnya serta mengerti cara mengaktualisasikannya dalam segala aspek kehidupan.

Salah satu aspek dalam kehidupan manusia yang penting untuk mengaktualisasikan empat sifat wajib Nabi dan Rasul ini adalah dalam bidang pemasaran. Seperti yang sudah dijelaskan pada bab sebelumnya, pemasaran konvensional berbeda dengan pemasaran syariah. Selain implementasi nilai-nilai akhlak yang terkandung dalam Al-Qur'am dan Hadis, pemasaran syariah juga diwarnai dengan konsep keteladanan sifat para Nabi dan Rasul tersebut.

\section{A. FATHONAH}

1. Hakikat Sifat Fathonah

Kata "fathonah" bisa diartikan dengan cerdas, pandai dan yang tidak pernah lupa. Para Nabi dan Rasul memiliki daya ingat yang cukup tinggi, sehingga mampu menjelaskan sesuatu yang sudah mereka pelajari dari Allah SWT dengan sangat terperinci.

Kecerdasan yang dimiliki para Nabi dan Rasul mampu memengaruhi orang-orang yang menjadi sasaran dakwah mereka, meskipun tidak semua dari orang-orang itu serta merta menerima dan meyakini ajaran yang disampaikan kepada mereka. Dengan kecerdasan itu pula para Nabi dan Rasul mampu memberikan penjelasan yang tepat, memberikan argument yang kuat dan mengatur strategi dakwah yang matang. 
Pada umumnya, seseorang akan mengakui kebenaran orang lain berdasarkan faktor kecerdasan orang itu. Orang lain dapat memercayainya jika ia memang terlihat sebagai pribadi yang cerdas, berwawasan luas dan pandai mengurai permasalahan dengan kecakapan ilmunya.

Islam memberikan anjuran kepada umatnya agar senantiasa menjadi orang-orang yang cerdas (fathonah). Hal ini sekaligus merupakan perintah agar umat Islam senantiasa belajar, mencari tahu dan mencari ilmu supaya bisa memperoleh kecerdasan. Banyak ayat Al-Qur'an yang secara tegas mengecam orang-orang yang tidak menggunakan akalnya dengan baik dan memerintahkan manusia untuk senantiasa belajar serta mencari karuniaNya berupa rezeki dan ilmu-Nya. Allah berfirman:

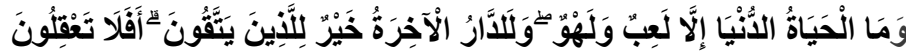

Dan tiadalah kehidupan dunia ini, selain dari main-main dan senda gurau belaka. Dan sungguh kampong akhirat itu lebih baik bagi orang-orang yang bertaqwa. Maka tidakkah kamu memahaminya? (QS. Al-An'am:32)

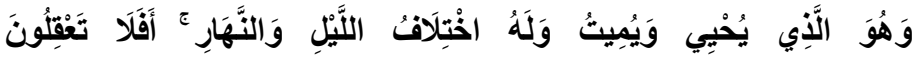
Dan Dialah yang menghidupkan dan mematikan, dan Dialah yang (mengatur) pertukaran malam dan siang. Maka Apakah kamu tidak memahaminya? (QS. AlMu'minun:80) 


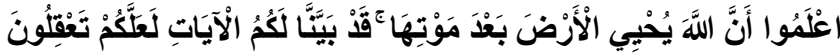

Ketahuilah olehmu bahwa sesungguhnya Allah menghidupkan bumi sesudah matinya. Sesungguhnya Kami telag menjelaskan kepadamu tanda-tanda kebesaran (Kami) supaya kamu memikirkannya (QS. alHadid: 17)

Pada setiap ayat tersebut di atas, Allah SWT memberi peringatan kepada manusia untuk menggunakan akal dengan sebaik-baiknya. Orang yang menggunakan akalnya dengan benar, maka dia akan taat kepada aturan-aturan Islam.

Sebagai salah satu sifat utama, fathonah merupakan sifat yang sudah selayaknya dimiliki Nabi dan Rasul. Jika Nabi dan Rasul tidak bersifat fathonah, mereka tidak akan mampu menjelaskan hujjah yang diperintahkan oleh Allah SWT, tidak bisa melaksanakan tugasnya dengan sempurna serta tidak bisa memberikan sanggahan yang tepat, seandainya dari kaum mereka melakukan penyanggahan atau bantahan.

Sifat fathonah yang merupakan perapaduan antara pengetahuan ('alim) dan hafalan (hafizh) telah berhasil membuat Nabi Yusuf a.s. dan timnya berhasil membangun Mesir.

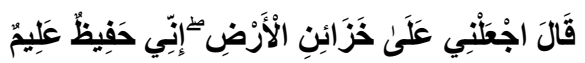


Berkata Yusuf: "Jadikanlah aku bendaharawan negara (Mesir); sesungguhnya aku adalah orang yang pandai menjaga, lagi pengetahuan." (QS. Yusuf: 55)

Kecerdasan juga dapat ditunjukkan dalam posisi manusia sebagai makhluk sosial. Seseorang dapat dikatakan cerdas apabila mampu menolong orang lain untuk memecahkan persoalan dan kesulitan yang dihadapi. Sebagaimana para Nabi dan Rasul, yang dengan kecerdasannya membuat mereka peduli terhadap persoalan yang dihadapi umat sekaligus mampu memberikan solusi atas masalah yang dihadapi.

2. Sifat Fathonah Rasulullah

Rasulullah SAW sebagai Nabi dan Rasul penutup memiliki sifat paling sempurna dari Nabi dan Rasul sebelumnya. Kecerdasan beliau yang banyak dikisahkan dalam Hadis-hadis, menonjol dalam berbagai peran dalam hidupnya, baik ketika beliau berperan sebagai pemimpin agama, kepala negara, kepala rumah tangga maupun kisah kecerdasan beliau sebagai seorang pedagang. Saat kota Mekkah dilanda banjir besar, bangunan Ka'bah runtuh. Kaum Quraisy pun bergotong royong membangun kembali bangunan tersebut. Konflik antara pemukapemuka Quraisy terjadi saat akan meletakkan kembali Hajar Awad ke tempatnya. Meletakkan Hajar Aswad adalah kemuliaan bagi bangsa Arab Quraisy dan membawa kemuliaan pula terhadap suku yang 
meletakkannya. Konflik itu hamper saja membawa perang saudara di antara mereka.

Akhirnya mereka membuat kesepakatan, siapa yang pertama masuk ke Masjidil Haram, orang itulah yang akan memutuskan suku mana yang berhak meletakkan Hajar Aswad. Saat mereka menunggu orang yang dimaksud, Rasulullah SAW (sebelum diangkat menjadi Rasul) masuk ke Masjidil Haram. Mereka pun langsung bersepakat mengangkat Rasulullah yang terkenal dengan gelar al-Amin, yang dapat dipercaya untuk membuat keputusan.

Setelah mendengar masalah yang dihadapi para kabilah, Rasulullah membentangkan sehelai kain surban dan meletakkan Hajar Aswad di tengah-tengah surban itu. Beliau meminta semua ketia kabilah memehang di setiap penjuru surban, lalu mengangkatnya bersama-sama. Sampai saat di tepi Ka'bah, Rasulullah mewakili semua suku meletakkan batu itu di tempat asalnya. Semua kaum merasa puas dengan langkah yang bijak dan adil itu.

Sifat fathonah mengantarkan Rasulullah (sebelum diangkat menjadi Nabi) mendapatkan keberhasilan dalam perniagaan yang dilakukannya. Keterampilan dan keahlian yang dimiliki oleh Rasulullah dalam berdagang menjadikannya seorang manajer pemasaran yang andal di industri perdagangan Siti Khadijah. 
Rasulullah SAW mencontohkan keteladanan sifat fathonah dalam bisnis adalah dengan tidak mengambil profit yang terlalu tinggi dibandingkan dengan penjual lainnya, sehingga hal ini dapat meningkatkan penjualan. Kecerdasan emosional yang dimiliki Rasulullah juga sangat baik dalam membangun sebuah jaringan dan kemitraan usaha. Tidak tanggung-tanggung, rekanan bisnis Rasulullah adalah pembesar-pembesar kaum Quraisy yang juga merupakan teman kakeknya, Abdul Muthalib. Jaringan yang dipupuknya dengan kepercayaan. Kepercayaan yang bibitnya adalah kejujuran.

Afzalurrahman dalam buku Muhammad sebagai Seorang Pedagang (2000) menuliskan, Rabi bin Badr pernah melakukan kerja sama dagang dengan Muhammad SAW. Ketika belakangan mereka bertemu lagi, Muhammad SAW mengatakan, "Apakah engkau masih mengenaliku?"

Rabi bin Badr menjawab, "Engkau pernah menjadi mitraku dan mitra yang paling baik pula. Engkau tidak pernah menipuku dan tidak pernah berselisih denganku."

Rasulullah SAW memiliki kompetensi dan kemampuan teknis yang terkait dengan usaha. Beliau memahami kondisi dan analisa pasar, mengenal dengan baik pasar-pasar dan tempat-tempat perdagangan di jazirah Arab. Beliau juga mengetahui seluk beluk aktivitas perdagangan dan bahayanya riba sehingga beliau menganjurkan jual-beli dan menghapuskan sistem riba. 
Rasulullah juga memiliki kemampuan merespon strategi pesaingnya. Dikisahkan ketika beliau di Mekkah, para pedagang dari kaum Quraisy ingin menjatuhkan bisnisnya dengan menjatuhkan harga dengan tidak wajar. Tetapi beliau menereapkan hukum supply dan demand. Beliau menyaisati dan bersabar hingga semua dagangan kompetitornya habis semua. Rasul baru menjual dagangannya ketika jumlah permintaan (demand) jauh lebih tinggi dari jumah penawaran (supply) di kota itu. Tak lama kemudian rakyat kita tersebut membeli barang dagangan Rasul dengan harga normal. Ketika rombongan pedagang itu pulang, Mekkah gempar. Semua pedagang rugi akibat banting harga kecuali Rasulullah yang untung besar. Itulah kejelian melihat, menganalisis dan memahami pasar sehingga dapat menguasai pasar yang ada.

Rasulullah pernah memberikan teknik sales promotion yang jitu kepada seorang pedagang. Dalam suatu kesempatan beliau mendapati seseorang sedang menawarkan barang dagangannya. Dilihatnya ada yang janggal pada diri orang tersebut. Beliau kemudian memberikan nasihat kepadanya,

"Rasulullah lewat depan seorang yang sedang menawarkan baju dagangannya. Orang tersebut jangkung sedang baju yang ditawarkan pendek. Kemudian Rasulullah berkata: "Duduklah! Sesungguhnya kamu 
menawarkan dengan duduk itu lebih mendatangkan rezeki."

Rasulullah kreatif dalam memilih lahan untuk berbisnis. Beliau tahu bahwa tanah kota Mekkah cukup keras dan tak bisa mengharapkan bisnis di bidang pertanian. Karena itulah beliau banting setir ke bidang perdagangan, setelah sebelumnya beliau menggembala. Dengan keberanian tingkat tinggi, akhirnya beliau meraup sukses besar setelah beberapa ali melewati ekspedisi perdagangan. Di sinilah kecerdasan dan kreativitas beliau teruji dengan kecerdasan tersebut beliau bisa bertahan hidup, malah menjadi mapan dengan menekuni dunia pergadangan. (Malahayati, 2010)

3. Fathonah dalam Pemasaran

Meneladani sifat fathonah dalam pemasaran berarti segala sesuatu aktivitas dalam manajemen oemasaran harus dilandasi dengan kecerdasan, yakni mengerahkan dan memaksimalkan kemampuan akal yang dimiliki untuk mencapai tujuan dan target. Fathonah juga berarti mengerti, memahami dan menghayato secara mendalam segala hal yang terjadi dalam tugas dan kewajiban. Fathonah berkaitan dengan kecerdasan, baik kecerdasan rasio, rasa maupun kecerdasan ilahiyah.

Seorang marketer yang cerdas akan mampu memahami, menghayati dan mengenal tugas dan tanggung jawabnya dengan sangat baik. Dengan sifat ini, 
marketer dapat menumbuhkan kreativitas dan kemampuan melakukan berbagai inovasi. Yang bermanfaat bagi perusahaan. Kreatif dan inovatif hanya dimiliki ketika seseorang melakukan upgrading keilmuan yang dimiliki baik melalui self learning process maupun melalui pendidikan formal serta pelatihan. Selain itu marketer yang cerdas dan bijaksana akan dapat menjawab pertanyaan customer terkait dengan produk dengan sebaik-baiknya, menjelaskan keunggulan produknya dibandingkan dengan pesaingnya dan membuat customer yakin dan terkesan dengan penjelasannya.

Fathonah juga terkait dengan kecerdasan marketer dalam hal menangkap selera pembeli yang berkaitan dengan barang maupun harta. Marketer yang cerdas juga tahu ketika pembeli benar-benar menginginkan produknya.

Dengan demikian, nilai fathonah ini sangat mendukung bagi perusahaan daam melakukan kegiatan pemasaran, karena marketer adalah pihak terdepan (front liner) yang harus mengerti mengenai seluruh aspek yang terkait dengan produk dan perusahaannya. Jika sebuah perusahaan memiliki sumber daya insani yang verdas, maka akan membantu perusahaan merai profit yang maksimal dengan tetap berada dalam koridor akhlak berdasarkan Al-Qur'an dan Hadis. Marketer yang cerdas 
juga akan memberikan nilai yang efektif dan efisien dalam melakukan kegiatan pemasaran.

\section{B. AMANAH}

\section{Hakikat Sifat Amanah}

Secara etimologis, kata "amanah" berarti jujur atau dapat dipercaya. Dari akar amanah yaitu umuna terbentuk beberapa pengertian lain, seperti aman, menyelamatkan, perlindungan, dan lain-lain. Bagi para Nabi dan Rasul, amanah berarti disampaikannya perintah Allah SWT kepada manusia dengan cara sebenarbenarnya. Tidak ada yang diubah, ditambah ataupun dikurangi dari yang diperintahkan-Nya itu, sehingga yan disampaikan benar-benar murni seperti yang diturunkan oleh-Nya kepada mereka. Dengan demikian orang yang amanah tidak akan melakukan kecurangan dengan amanat yang harus disampaikan. Oleh karena itu, para Nabi dan Rasul dinilai aman, terlindungi dan selamat dari upaya-upata melakukan manipulasi terhadap segala sesuatu yang harus disampaikan. Itulah sebabnya mereka disebut terpercaya atau amanah.

Seperti perkataan Nabi Hud dalam firman Allah SWT:

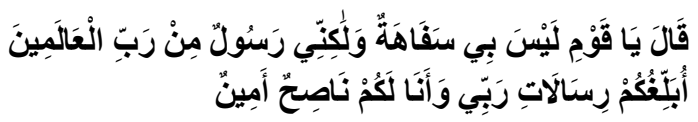

Hud berkata: "Hai kaumku, tidak ada padaku kekurangan akal sedikitpun, tetapi aku ini adalah utusan dari Tuhan semesta alam. Aku menyampaikan amanat-amanat 
Tuhanku kepadamu dan aku hanyalah pemberi nasihat yang terpercaya bagimu." (QS. Al-A'raf: 67-68)

Dalam ayat itu Nabi Hud menegaskan bahwa ia sama sekali bukanlah orang yang kurang akal (gila). Hal ini menandakan bahwa risalah yang dibawa olehnya benarbenar disampaikan dengan jalan amanah, yakni selamat dari kemungkinan salah, keliru dan penuh penyimpangan. Hal itu sangat mungkin terjadi apabila dilakukan oleh seorang yang akalnya kurang sehat dan sempurna.

Oleh karena itu, para Nabi dan Rasul memang diberikan tugas untuk menyampaikan perintah (wahyu) Allah SWT kepada umat manusia. Informasi apa pun yang mereka sampaikan pasti dapat dipercaya kebenarannya (amanah), mengingat para Nabi dan Rasul termasuk orang-orang yang jujur dan cinta kepada kebenaran.

Allah SWT memerintahkan manusia untuk memiliki sifat amanah, seperti firman-Nya dalam anNisaa' (4): 58 :

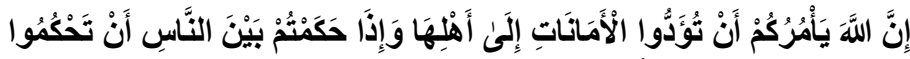

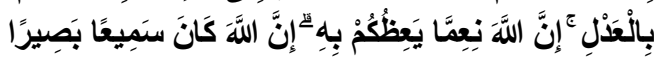

Sesungguhnya Allah menyuruh kamu menyampaikan amanat kepada yang berhak menerimanya, dan (menyuruh kamu) apabila menetapkan hukum di antara manusia suapaya kamu menetapkan dengan adil, sesungguhnya Allah memberi pengajaran yang sebaik- 
baiknya kepadamu. Sesungguhnya Allah adalah Maha Mendengar lagi Maha Melihat.

Dalam ayat ini, Allah tidak sekadar memerintahkan agar kita bersifat amanah dan adil, melainkan juga menegaskan bahwa Dia senantiasa mengawasi dan memantau hamba-Nya dalam menegakkan amanah dan keadilan itu. Sehingga tidak akan ada pelanggaran terhahap amanah dan keadilan yang benar-benar lepas dari pantauannya. Isyarat mengenai perintah amanah juga ditegaskan dalam sabda Rasulullah SAW yang diriwayatkan Abu Hurairah r.a.:

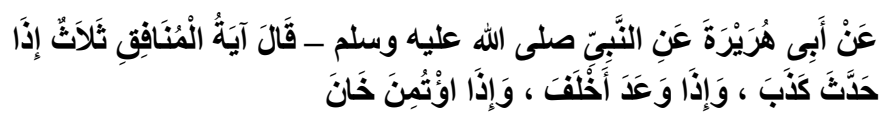

Dari Abu Hurairah r.a. ia berkata: Rasulullah SAW bersabda: "Tanda-tanda orang munafik itu ada tiga; jika berkata ia bohong, jika berjanji ia mengingkari, dan jika dipercaya ia berkhianat." (Muttafaqun ‘alaih)

Amanah jauh menjamah rona psikologi yang paling dalam. Sebab amanah mementingkan tanggung jawab yang sangat hakiki dalam hubungannya dengan umat manusia yang yakin bahwa ada yang selalu mengawasi pelaksanaan tugasnya. Dalam islam diyakini bahwa setiap tindak-tanduk manusia selalu berada dalam pengawasan malaikat yang senantiasa mencatat kebaikan dan keburukan manusia. Dalam konteks inilah sifat amanah berkiprah. (Al-Arif, 2012) 


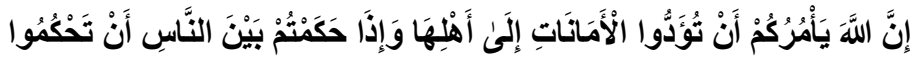

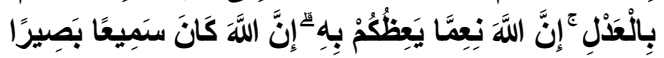

Sesungguhnya Allah menyuruh kamu menyampaikan amanat kepada yang berhak menerimanya, dan (menyuruh kamu) apabila menetapkan hukum di antara manusia suapaya kamu menetapkan dengan adil, sesungguhnya Allah memberi pengajaran yang sebaikbaiknya kepadamu. Sesungguhnya Allah adalah Maha Mendengar lagi Maha Melihat. (QS. an-Nisaa': 58)

Dengan adanya sifat amanah bagi para Nabi dan Rasul, maka hal itu membutikan bahwa apa pun yang berkenaan dengan wahyu Allah SWT adalah merupakan suatu kebenaran yang tidak terbantahkan. Dalam hal ini kebenaran wahyu-Nya didukung oleh sifat amanah mereka. Sehingga tidak ada keraguan sedikitpun bahwa yang dibawa oleh mereka memang suatu kebenaran yang berasal dari-Nya semata.

Selain itu dengan sifat amanah maka tidak akan terjadi penyelewengan sedikitpun terhadap yang diwahyukan oleh Allah SWT kepada mereka. Semua yang diperintahkan oleh-Nya sudah disampaikan dengan benar dan terpercaya oleh para utusan-Nya. Dengan sifat amanah yang dimiliki oleh para Nabi dan Rasul, tidak ada alasan unruk menolak kebenaran yang dibawa oleh mereka. Jika ada penolakan, maka hal itu disebabkan oleh keengganan kaum tersebut untuk meninggalkan kebiasaan lama yang sudah diwarisi dari nenek moyang. 
Sifat amanah yang menjadi penguat bagi kebenaram wahyu Allah SWT menjadikan manusia tidak akan pernah memiliki kemampuan untuk menandingi sesuatu yang diturunkan oleh-Nya kepada para utusanNya. Seandainya yang disampaikan oleh mereka hanya rekaan, tentunya tidak mustahil orang lain bisa menirunya.

Bukan perkara yang mudah untuk menjadi manusia berkepribadian amanah. Sebab sifat ini mengharuskan kita memiliki ketetapan jiwa agar tidak melakukan pelanggaran terhadap kepercayaan yang diberikan oleh orang lain, meskipun peluang untuk melanggar sangat terbuka lebar.

Sifat amanah ini akan membentuk kredibilitas yang tinggi dan sikap penuh tanggung jawab pada setiap individu Muslim. Kumpulan individu dengan kredibilitas yang tinggi akan melahirkan masyarakat yang kuat, karena dilandasi oleh saling percaya antar anggotanya. Sifat amanah memainkan peranan yang fundamental dalam ekonomi dan bisnis, karena tanpa kredibilitas dan tanggung jawab, kehidupan ekonomi dan bisnis akan hancur.

Integritas seseorang akan terbentuk dari sejauh mana orang tersebut dapat memelihara amanah yang diberikan kepadanya. Pebisnis yang baik adalah yang mampu memelihata integritasnya. Integritas yang terpelihara akan menimbulkan kepercayaan (trust) bagi 
nasabah, mitra bisnis dan bahkan semua stakeholder dalam suatu bisnis.

Konsekuensi amanah adalah mengembalikan setiap hak kepada pemiliknya, baik sedikit ataupun banyak, tidak mengambil lebih banyak daripada yang ia miliki dan tidak mengurangi hak orang lain baik itu berupa hasil penjualan, fee, jasa atau upah buruh.

Dalam pandangan Islam, orang yang benar-benar amanah dalam menerima dan menjalankan suatu kewajibannya merupakan pribadi yang sangat mulia. Sebaliknya, bagi orang yang melanggarnya (khianat), ia termasuk orang yang dinilai zalim dan bodoh. Sifat amanah termasuk sifat para Nabi dan Rasul yang patut diteladani. Dengan menjalankan sifat amanah, tidak hanya kepercayaan dari orang lain yang didapatkan, namun lebih dari itu, orang yang bersifat amanah akan memperoleh derajat kemuliaan di sisi Allah SWT.

2. Sifat Amanah Rasulullah

Sifat amanah Rasulullah SAW seperti sifat-sifatnya yang utama adalah lengkap sempurna, seperti tercermin dalam berbagai kisah selama hidupnya, baik sebelum maupun sesudah beliau diangkat menjadi Nabi.

Sewaktu Rasulullah membawa barang dagangan Siti Khadijah ke Syam, cara beliau menjual dagangan itu tidaklah seperti kebanyakan orang karena beliau tidak suka mengikuti cara-cara yang telah biasa dilakukan oleh 
orang banyak. Cara beliau berdagang adalah berapa harga pokok dari Khadijah beliau sebutkan dengan sebenarnya kepada pembeli dan tentang keuntungan bagi beliau, itu terserah pada pembeli. Oleh sebab itu, para saudagar di negeri Syam senang sekali membeli barang dagangan beliau karena mereka merasa tidak akan tertipu dalam perkara harga barang yang akan dibelinya.

Adapun tentang keuntungan bagi beliau, para pembelinya telah mengira-ngira sendiri dan memberi dengan cukup, sekadar untuk menutup biaya perjalanan antara Mekkan dan Syam pulang pergi.

Maisarah melihat tindakan beliau dalam menjual barang dagangan semacam itu. Dia sampai tercengan dan heran, tetapi tidak berani berkata sepatah kata pun. Cara beliau menjual barang dagangan semacam itu tidak disukai oleh kawan-kawan beliau dari Mekkah yang samasama menjualkan barang perniagaan Khadijah, karena mereka merasa tidak dapat keuntungan yang luar biasa. Sungguhpun demikian beliau tetap menjalankan cara seperti itu dan dagangan beliau telah habis terjual dalam waktu yang sebentar dengan mendapat keuntungan yang tidak sedikit (Chalil, 2006)

Rasulullah selalu menepati janji dan mengantarkan barang dagangan dengan standar kualitas sesuai dengan permintaan pelanggan sehingga tidak pernah membuat pelanggannya mengeluh atau bahkan kecewa. Saat menjadi pedagang, Nabi Muhammad selalu 
mengembalikan hak milik atasannya, baik itu berupa hasil penjualan maupun sisa barang. Menjaga nama baik (bramding), Rasulullaj selalu menggunakan cara ini sebagai modal utama, track record sebagai orang terpercaya (al-Amin) justru paling dicari dan siapapun ingin bekerja sama dengannya.

Apa yang beliau lakukan itu merupakan langkah untuk membangun kepercayaan dan dapat dipercaya dalam bisnis. Inilah yang dalam bisnis saat ini disebut dengan trust yang nilainya jauh lebih penting daripada kapital. Sebab dalam bisnis, uang bukanlah kapital nomor wahidnya adalah kepercayaan (money is not number one capital in business, the number one capital is trust). Adapun dalam bahasa Arab, trust itu hampir identik dengan gelar yang diberikan oleh penduduk Mekkah kepada Nabi Muhammad SAW yaitu al-Amin.

Karena itulah beliau semakin dipercaya, baik oleh para pembeli, pedagang, mitra usaha, ataupun pemilik modal. Dengan gelar al-Amin tersebut, reputasi dan kredibilitas beliau sebagai seorang pedagang semakin terkenal. Maka dari itu, banyak pihak terutama dari kalangan pedagang yang tertarik untuk menjalin kemitraan usaha dengan beliau. Inilah yang mejadi pintu masuk aliran modal usaha untuk dikelola oleh beliau dengan mendapat imbalan berupa upah ataupun bagi hasil atas keuntungan yang didapat. 
Selain memaparkan rahasia bisnis Rasulullah, Laode M. Kamaluddin Ph.D juga memberi penekanan khusus pada pentingnya menjaga amanah. Sebab kesuksesan Raslullah tak bisa lepas dari keberhasilannya menjaga kepercayaan (amanah), ini merupakan ciri utama dari aktivitas bisnis yang dilakukan oleh Rasulullah sehingga tidak ada satupun orang yang berinteraksi dengan beliau kecuali mendapatkan kepuasan yang luar biasa. Dan sangat pantas jika beliau mendapatkan gelar al-Amin. Itulah modal terbesar yang tidak bisa ditawar-tawar jika kita ingin sukses dalam berbisnis seperti Rasulullah.

\section{Amanah dalam Pemasaran}

Amanah berarti merasa memiliki tanggung jawab dalam melaksanakan tugas dan kewajiban yang diberikan kepadanya. Amanah dapat ditampilkan dalam bentul keterbukaan, kejujuran, dan pelayanan yang optimal kepada customer dan juga berlaku ihsan (berupaya memberikan yang terbaik) dalam segala hal (Al-Arif, 2012).

Nilai amanah sangat penting bagi seorang marketer. Marketer yang amanah tidak mengurangi apaapa yang tidak boleh dkurangi dan sebaliknya tidak menambahkan hal-hal yang tidak sesuai dengan produknya. Selain itu amanah bagi seorang marketer berarti menjaga nama baik perusahaannya dengan menampilkan image baik yang sesuai dengan karakteristik perusahaan, karena marketer adalah garda terdepan, 
perwakilan perusahaan yang langsung berhadapan dengan konsumen sehingga pandangan dan pendapat customer tentang perusahaan juga banyak dipengaruhi oleh perilaku marketer.

Marketer yang amanah berarti ia dipercaya oleh perusahaan dan customernya. Bagi perusahaan, seorang marketer yang amanah akan membawa keuntungan yang besar. Di samping karena mereka melakukan pekerjaannya dengan baik, perusahaan akan mendapat keuntungan dari image yang terbangun oleh customer akan keamanahan dari marketer perusahaan tersebut. Sehingga customer akan tertarik oleh sebuah produk atau usaha karena peran sosok marketer yang amanah.

\section{SHIDDIQ}

1. Hakikat Sifat Shiddiq

Kata shiddiq berasal dari shadaqa yang berarti benar, nyata, berkata benar, menepati janji, benar perkataan atau perkiraannya. Dari kata yang sama juga muncul beberapa pengertian, seperti "yang membuktikan ucapan dengan perbuatannya, yang berbakti dan selalu memercayai, keadaan dapat dipercaya serta kejujuran dan yang banyak suka terhadap kebenaran." (Laranta, 2013) Dalam pengertian yang lain shiddiq berarti mengatakan yang benar dan terang atau memberi kabar sesuai dengan kenyataan yang diketahui oleh si pembicara dan tidak diketahui oleh orang lain (Al-Hufiy, 2000). 
Shiddiq merupakan salah satu sifat yang diperintahkan dalam agama Islam. Orang-orang yang beriman harus memiliki sifat shiddiq demi melaksanakan perintah agama, bukan untuk mendapatkan keuntungan materi maupun nonmateri. Mereka tetap bersifat shiddiq meskipun sifat shiddiq itu akan merugikan kepentingan yang bersifat duniawi. Shiddiq merupakan salah satu sifat mulia yang harus dimiliki oleh setiap orang yang ingin hidup dan mati secara mulia.

Para Nabi dan Rasul wajib memiliki sifat shiddiq, artinya segala perkataan dan perbuatan mereka terpelihara dari kebohongan. Karena tugas utama setiap Rasul adalah menyampaikan wahyu kepada umatnya, jika mereka tidak bersifat shiddiq maka umat akan meragukan setiap wahyu yang disampaikannya. Tidak hanya berkata jujur, para Nabi dan Rasul menyukai kejujuran, suka orang-orang yang jujur dan senantiasa menganjurkan kejujuran.

Sifat shiddiq dijadikan sifat Rasulullah SAW sebagaimana Allah SWT berfirman:

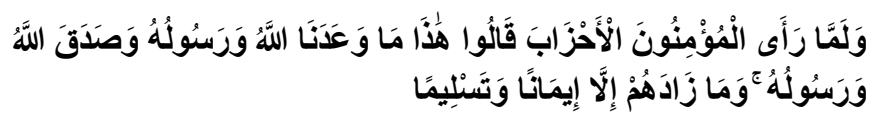

Dan tatkala orang-orang mukmin melihat golongangolongan yang bersekutu itu, mereka berkata: "Inilah yang dijanjikan Allah dan Rasul-Nya kepada kita". Dan 
benarlah Allah dan Rasul-Nya. Dan yang demikian itu tidaklah menambah kepada mereka kecuali iman dan ketundukan." (QS. al-Ahzab: 22)

Begitu juga Allah SWT menjanjikan pahala bagi orang-orang yang jujur dan mengancam orang yang berdusta dengan siksaan. Hal ini sebagaimana difirmankan oleh Allah SWT:

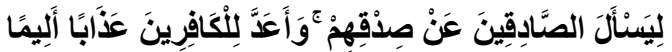

Agar Dia menanyakan kepada orang-orang yang benar tentang kebenaran mereka dan Dia menyediakan bagi orang-orang kafir siksa yang pedih. (QS. al-Ahzab: 8)

Allah SWT juga berfirman:

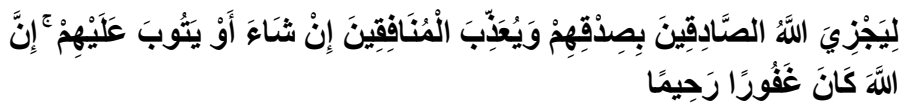

Supaya Allah memberikan balasan kepada orang-orang yang benar itu karena kebenarannya, dan menyiksa orang munafik jika dikehendak-Nya, atau menerima taubat mereka. Sesungguhnya Allah adalah Maha Pengampun lagi Maha Penyayang. (QS. al-Ahzab: 24)

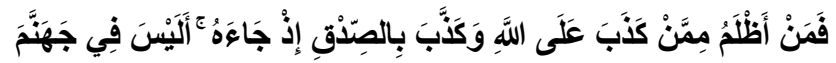


membawa kepada neraka. Dan sesungguhnya seorang pendusta akan ditulis di sisi Tuhan sebagai orang yang sangat pendusta." (HR. Bukhari-Muslim dari Ibnu Mas'ud)

2. Sifat Shiddiq Rasulullah

Orang-orang yang mengenal Rasulullah SAW dan bergaul dengan beliau sejak kecil sepakat bahwa beliau adalah seorang yang jujur dan terpercaya. Mereka belum pernah mendengar kata-kata dusta dari lisan beliau. Di antara buktinya adalah sebagai berikut:

Dari Abu Hurairah r.a. bahwa Rasulullah SAW bersabda, "Sesungguhya aku hanya berkata benar." Sebagian sahabatnya berkata, "Namun engkau suka berkelakar kepada kami wahai Rasulullah." la bersabda, "Aku hanya berkata benar." (HR. Ahmad)

Orang-orang Quraisy sepakat bahwa Rasulullah SAW merupakan orang yang jujur dan terpercaya. Ini terbukti ketika beliau mengumpulkan kaum Quraisy untuk menyampaikan risalah yang dibawanya. Pada saat itu Rasulullah SAW naik ke bukit Shafa dan berkata, "Alangkah indahnya pagi hari ini!" Orang-orang Quraisy datang berkumpul mengelilingi beliau dan bertanya, "Apa yang telah terjadi padamu?" Beliau menjawab, "Bagaimana pendapat kalian semua jika aku memberi kabar bahwa musuh akan menyerang kamu di waktu pagi hari atau sore hari, apakah kamu semua kan membenarkan aku?" Mereka menjawab, "Ya, kami belum 
pernah mengetahui engkau berdusta!" Beliau berkata, "Sesungguhnya aku memperingatkan kamu akan datangnya siksa yang berat." Abu Lahab berkata, "Binasalah engkau, apakah untuk ini engkau mengumpulkan kami?" Kemudian Allah SWT menurunkan ayat:

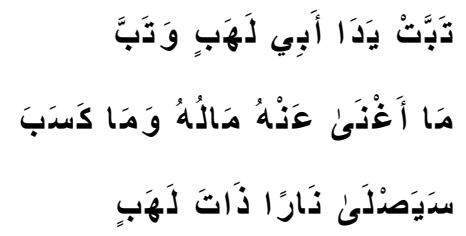

Binasalah kedua tangan Abu Lahab dan sesungguhnya dia akan binasa. Tidaklah berfaedah kepadanya harta bendanya dan apa yang ia usahakan. Kelak dia akan masuk ke dalam api yang begejolak. (QS. al-Masad: 1-3)

Walaupun mereka mendustakan tentang kenabian Rasulullah SAW, tidak seorang pun berani mendustakannya hal lain. Abu Jahal berkata pada beliau, "Kami tidak pernah mendustakan engkau dan engkau bukanlah seorang pendusta. Tetapi kami mendustakan apa yang engkau bawa itu!" Lalu Allah SWT berfirman:

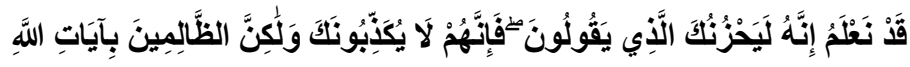
يَجْحَدُونَ

Sesungguhnya Kami mengetahui bahwasanya apa yang mereka katakan itu menyedikan hatimu, (janganlah kamu 
bersedih hati), karena mereka sebenarnya bukan mendustakan kamu, akan tetapi orang-orang yang zalim itu mengingkari ayat-ayat Allah. (QS. al-An'aam: 33)

Ketika Akhnas bin Syariq berjumpa dengan Abu Jahal pada Perang Badar ia berkata, "Wahai Abdul Hakam (panggilan Abu Jahal), di sini tidak ada orang lain kecuali hanya aku dan engkau yang mendengar pembicaraan kita, oleh karena itu, beritahukanlah kepadaku tentang Muhammad. Apakah ia orang yang benar atau pendusta?" Abu Jahal menjawab, "Demi Allah sesungguhnya Muhammad itu adalah orang yang benar. Dia tidak pernah berdusta."

Orang-orang Quraisy menyusun renccana jahat untuk menyiarkan kabar kepada irang yang datang ke Mekkah bahwa Muhammad adalah tukang sihir. Lalu kebohongan ini ditentang oleh orang yang sangat memusuhi beliau, yaitu Nadhar bin al-Harits. Ia berkata, "Muhammad sejak mudanya paling disenangi di kalangan kalian, yang paling benar kata-katanya dan paling jujur. Sekarang setelah kamu melihat uban memutih di jambangnya dan membawa agama, lalu kamu mengatakan bahwa dia tukang sihit. Demi Allah, dia bukanlah tukang sihir."

Ketika raja Rum Heraclius bertanya kepada Abu Sufyan dan rombongannya yang terdiri atas beberapa orang Quraisy setelah perjanjian Hudaibiyah, "Apakah kamu semua melihat dia (Muhammad SAW) berdusta 
sebelum dia berkata tentang agama?" Abu Sufyan menjawab, "Tidak!" Raja Heraclius berkata, "Tidak mungkin dia menjauhi dusta terhadap manusia, kemudian dia berdusta terhadap Allah."

Ketika Ali bin Abi Thalib r.a. menceritakan sifat Rasulullah SAW, ia berkata, "Sesungguhnya beliau adalah manusia yang paling benar ucapannya." Disebutkan dalam Hadis yang diriwayatkan oleh Ibnu Umar r.a. bahwa Rasulullah SAW dapat diketahui apakah beliau marah atau senang. Beliau tidak pernah mengatakan kata-kata yang mungkar dan tidak menyatakan, baik dalam keadaan senang atau dalam keadaan marah, kecuali yang benar dan beliau senang dan bila memberi nasihat, beliau memberikannya dengan sungguh-sungguh. Apabila marah karena Allah SWT, taka da yang dapat menahan marahnya kecuali penyebab marahnya itu hilang. Rasulullah SAW tidak pernah marah karena kepentingan pribadi dan tidak mau membela kepentingannya itu.

Rasulullah SAW adalah seorang pedagang yang jujur dan adil (fairplay) dalam membuat perjanjian bisnis dan tidak pernah membuat para pelanggannya mengeluh (complain). Beliau selalu menepati janjinya dan dalam menyerahkan/mengirimkan barang-barang pesanannya selalu tepat waktu dan tetap mengutamakan kualitas barang yang telah dipesan dan disepakati sebelumnya. Dalam berperilaku bisnis beliau selalu menunjukkan rasa penuh tanggung jawab dan memiliki integritas yang tinggi 
di mata siapapun. Reputasi beliau sebagai seorang pedagang yang jujur dan adil telah dikenal luas (Afzalurrahman, 2000).

Dalam melakukan transaksi bisnis, Rasulullah SAW menggunakan kejujuran sebagai etika dasar. Kejujuran Rasulullah SAW dalam bertransaksi dilakukan dengan cara menyampaikan kondisi riil barang dagangannya. Beliau pernah melarang para pedagang untuk meletakkan barang busuk/jelek di dalam dagangannya. Beliau selalu memberikan barang sesuai dengan adanya dan terbaik bagi konsumennya.

Kejujuran dan keterbukaan Rasulullah dalam melakukan transaksi perdagangan merupakan teladan bagi seorang pengusaha generasi selanjutnya. Reputasi sebagai pedagang yang benar-benar jujur telah tertanam dengan baik. Sejak muda, beliau selalu memperlihatkan rasa tanggung jawabnya terhadap setiap transaksi yang dilakukan.

Tidak ada tawar-menawar dan pertengkaran antara Rasulullah dan para pelanggannya sebagaimana sering terjadi pada waktu itu di pasar-pasar. Segala permasalahan antara Rasulullah dan para pembeli atau penjual selalu diselesaikan dengan damai dan adil tanpa ada kekhawatiran akan terjadi unsur penipuan di kedua belah pihak. Kejujuran, keadilan dan konsistensi yang ia pegang teguh dalam bertransaksi telah menjadi teladan abadi dalam segala jenis masalah perdagangan. 


\section{BAB III \\ Implementasi Pemasaran Syariah}

A. Empat Aksioma Sistem Ekonomi Islam

Manusia selalu berhubungan dengan muamalah untuk memenuhi segala tingkat kebutuhannya. Muamalah berasal dari bahasa Arab yang secara etimologis sama dan semakna dengan kata mufa'alah (saling berbuat) (Mardani, 2012). Kata tersebut menggambarkan suatu aktivitas yang dilakukan oleh seseorang dengan seorang atau beberapa orang dalam memenuhi kebutuhan masing-masing. Muamalah dibagi menjadi dua cakupan, yakni: Muamalah yang mencakup masalah al-ahwal alsyahsyiyah (hukum keluarga yang mengatur hubungan antara suami istri, anak, dan keluarganya), di mana pokok kajiannya meliputi munakahat, mawaris, wasiat, dan wakaf. Kedua, muamalah yang mencakup jual-beli, gadai, salam, pemindahan utang, serta yang lainnya.

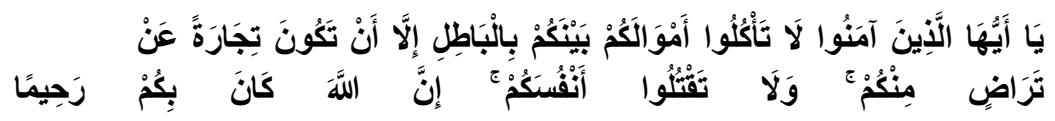
Wahai orang-orang yang beriman! Janganlah kamu saling memakan harta sesamamu dengan jalan yang batil (tidak benar), kecuali dengan jalan perdagangan yang berlaku atas dasar suka sama-suka di antara kamu. Dan janganlah kamu membunuh dirimu. Sesungguhnya Allah adalah Maha Penyayang kepadamu. (Qs. an-Nisaa': 29)

Ayat Al-Quran di atas menunjukkan bahwa Islam mengajarkan kepada umatnya untuk berbuat baik terhadap 
sesama dalam segala hal, khususnya dalam aktivitas perdagangan. Berdasarkan perspektif Islam, berbisnis atau berdagang haruslah dalam kerangka kerja sama yang saling menguntungkan, dan menghindari cara-cara yang batil. Salah satu cara yang ditempuh dalam proses bisnis berbasis syariah, guna mencapai hasil yang saling menguntungkan itu, adalah mengimplementasikan akad melalui proses yang jujur dengan pendekatan take and give, hubungan baik, dan dengan hasil win-win (Alwi, 2013).

Navqi (1981) dalam Mohammed (2007) Ethics and Economics: An Islamic Synthesis, menciptakan empat aksioma berdasar nilai Al-Quran dan Hadis yang dibutuhkan bagi sistem ekonomi Islam. Keempat aksioma tersebut kemudian digunakan sebagai landasan teori oleh Mohammed (2007) dalam penelitiannya yang mengangkat permasalahan bagajmana penerapan konsistensi kerangka konseptual CSR (Corporate Social Responsibility) Islam pada praktik bisnis kontemporer saat ini, di mana survei tersebut dilakukan terhadap bank syariah yang terletak di berbagai belahan dunia. Empat aksioma tersebut akan diuraikan satu per satu di bawah ini.

1. Unity (Tauhid)

Aksioma ini berhubungan dengan konsep tauhid yaitu dimensi hubungan vertikal dengan Allah SWT. Aspek politik. ekonomi, sosial, dan religius dari kehidupan manusia pada akhirnya harus dapat dipertanggungjawabkan kepada Allah SWT. 
Sebagai khalifah Allah di muka bumi, manusia harus mampu memaksimalkan sumber daya alam yang diberikan dan mendistribusikannya secara adil dan merata di antara sesama. Sistem sosial Islam sangat mengutamakan adanya perilaku non-diskriminasi dalam setiap aktivitas manusia. Aksioma unity merupakan konsep yang menggambarkan tujuan dan tingkah laku manusia dalam melakukan segala tanggung jawabnya dan mempertahankan (menerapkan) keadilan sebagai bagian dari kepercayaannya terhadap Allah SWT. Ada tiga kategori yang diklasiflkasikan dalam aksioma ini, yaitu: (a) trustworthiness, (b) avoid hoarding wealth avariciously, dan (c) avoid discrimination.

Trustworthiness atau kepercayaan merupakan bagian penting dari segala macam jenis urusan bisnis. Mohammed (2007) menjelaskan bahwa semua responden dalam penelitiannya setuju bahwa telah menjadi tanggung jawab (amanah) mereka untuk menjaga dana klien yang dipercayakan kepada mereka. Menurut mereka, hal tersebut dilakukan karena berdasarkan pada prinsip-prinsip syariah, yang mana pada akhirnya dapat menumbuhkan rasa kepercayaan klien. Salah satu respons dari responden yang diwawancarai adalah sebagai berikut: "Trustworthiness is very important for us (Islamic banks) as custodian ofothers wealth. It is our responsibility, when we have other people' money, to do everything according to Shariah that is why people come to us..." Dengan demikian, merupakan hal yang sangat 
penting bagi para pelaku bisnis, khususnya pelaku Muslim, untuk menumbuhkan rasa kepercayaan dan kesetiaan dalam diri pelanggan/konsumen.

Penimbunan kekayaan kekayaan adalah hal yang dilarang dalam Islam. Islam memiliki hukum yang tegas mengenai orang yang suka menimbun harta kekayaan (hoarder).

Penimbunan kekayaan/ sumber daya alam dapat memberikan efek buruk bagi siklus ekonomi dan moral manusia. Efek buruk tersebut disebabkan karena penimbunan yang dilakukan oleh seorang atau beberapa orang dapat menghilangkan kesempatan orang lain untuk memiliki sumber daya alam yang seharusnya dapat ia gunakan untuk aktivitas konsurntif maupun produktif. Hilangnya kesempatan tersebut berarti hilang pula kesempatan untuk bekerja, yang akhimya akan menyebabkan pengangguran besar-besar. Penimbunan sumber daya alam juga memberi dampak terhadap nilai jual atau harga sumber daya alam yang bersangkutan. Tingginya nilai jual menyebabkan menurunnya daya beli masyarakat, dan dalam jangka panjang akan menimbulkan kemiskinan.

Ekonomi Islam memiliki konsep tersendiri mengenai penguasaan harta kekayaan/sumber daya alam. Umat Muslim tidak pernah dilarang untuk mengumpulkan harta sebanyakbanyaknya, dengan satu syarat yakni: harta tersebut 
tidak hanya berputar di kalangan tertentu saja. Pajak dalam Islam atau yang dikenal sebagai zakat berperan penting dalam redistribusi kekayaan umat Muslim. Adanya zakat (zakat mal atau zakat titri) mampu memperkecil jurang pemisah antara si kaya dan si miskin. Pendayagunaan zakat pun tidak hanya sebatas konsumtif saja, melainkan juga produktif.

Terakhir adalah avoid discrimination. Penegakan prinsipprinsip syariah menjadi tugas penting bagi para pelaku bisnis, seperti melarang diskriminasi dalam segala bentuk. Dalam praktiknya, mereka harus peduli tentang hak-hak karyawan yang dipekerjakan dan hak-hak partner/pelanggan.

2. Equilibrium (Al-`Adl)

Equilibrium mencerminkan adanya unsur keseimbangan antara berbagai aspek kehidupan manusia (politik, ekonomi, sosial, dan religius) dengan tujuan untuk menghasilkan tatanan sosial terbaik. Aksioma ini merupakan dimensi horizontal Islam, artinya hubungan baik yang terjalin antara manusia dengan sesama yang dapat dicapai melalui hati nurani manusia.

Pemerataan kekayaan (sekali lagi) menjadi aspek penting dari aksioma ini. Para pelaku bisnis yang sadar akan tanggung jawab sosial mereka akan menjaga kepatuhan terhadap konsep sosial ekonomi Islam. Konsep sosial ekonomi Islam menitikberatkan adanya pemerataan dan keadilan. Agar 
tercipta pemerataan dan keadilan diperlukan adanya usaha untuk memperlancar arus barang dan jasa dari produsen ke konsumen, oleh karena itu diperlukan saluran distribusi yang tepat. Fungsi dan peranan saluran distribusi adalah sebagai salah satu aspek kegiatan pemasaran perusahaan yang berkaitan dengan produk, penetapan harga, dan promosi (Aziz, 2008).

\section{Free Will (Ikhtiar)}

Kemampuan manusia untuk bertidak tanpa adanya paksaan dari pihak eksternal sebagai wakil Allah SWT di muka bumi. Pihak ekstemal yang dimaksud adalah makhluk ciptaan Allah SWT selain manusia itu sendiri. Mohammed (2007) membagi aksioma free will ke dalam tiga kategori utama yang dikutip dalam kalimat berikut ini:

"...According to the Islamic belief sistem of total submission to the will of Allah (TME), Muslims are obliged to follow the divine commandments. The principle of total submission permeates every aspect of a Muslim of a Muslim's life including commercial transactions. Thus, Muslims are expected to contribute to society, fulfil all obligations pertaining to their social responsibility and care for less fortunate..."

Contribution to the well-being society adalah usaha atau kontribusi yang dilakukan untuk menciptakan (meningkatkan) kesejahteraan masyarakat. Jika dikaitkan dengan transaksi bisnis, maka kategori ini diilustrasikan: 
seorang penjual yang menawarkan berbagai pilihan barang/jasa yang dibutuhkan dan/atau diinginkan oleh masyarakat, namun keputusan untuk membeli atau tidak sepenuhnya tergantung pada kehendak si pembeli. Hal tersebut disebabkan karena bisa saja terdapat penjual lain yang menawarkan barang/jasa yang sama dengan insentif yang lebih menarik dan menguntungkan bagi kesejahteraan pembeli. Oleh karena itu, merupakan suatu tugas setiap penjual untuk memberikan penawaran dan pelayanan yang terbaik yang dirasa dapat menarik masyarakat luas tidak hanya dari sisi kuantitas (jumlah banyaknya pembeli), namun juga dari sisi kualitas yang dapat memuaskan pembeli.

Fulfilling obligations adalah suatu hal yang harus dipenuhi terlebih dahulu sebelum melakukan hal lain yang sifatnya tidak terlalu primer. Contoh dalam transaksi bisnis adalah berinvestasi atau memproduksi barang/jasa yang dibutuhkan atau bermanfaat bagi masyarakat luas, setelah semua kebutuhan terpenuhi, barulah berinvestasi atau memproduksi barang/ jasa sekunder dan tersier. Ekonomi Islam mendorong investasi dalam proyek-proyek berbasis masyarakat yang akan bermanfaat baik bagi bisnis itu sendiri maupun masyarakat yang lebih besar.

Kategori yang terakhir adalah care for the less fortune/down trodden in society, yaitu keberpihakan Islam terhadap kaum yang lemah dan kurang beruntung. Mereka yang kurang beruntung diberikan bantuan oleh sesama Muslim yang bernasib sebaliknya, oleh sebab itulah zakat 
menjadi pengeluaran wajib bagi setiap Muslim yang hartanya telah memenuhi syarat-syarat wajib zakat. Tujuan utama dari zakat adalah meningkatkan taraf hidup masyarakat yang kurang mampu sehingga sangat diharapkan dapat-mengubah status mereka yang awalnya sebagai penerima zakat (mustahik) menjadi pemberi zakat (muzakki).

Free will merefleksikan kebebasan manusia untuk melakukan sesuatu yang berdasar pada hasrat dalam diri masingmasing. Namun, dalam Islam "kebebasan" itu harus dilandasi dengan kesadaran adanya pengawasan dari Allah SWT dan kewajiban melaksanakan segala perintah dan menjauhi larangan dari-Nya. Adanya batasan dan larangan yang jelas akan membedakan seorang Muslim dari nonMuslim di dalam setiap perilaku dan keputusan yang diambil, termasuk dalam perilaku transaksi komersial (perdagangan).

\section{Responsibility (Fardh)}

Aksioma terakhir ini saling berhubungan satu sama lain dengan tiga aksioma sebelumnya. Responsibility adalah tindakan pertanggungjawaban oleh manusia kepada Allah SWT, yang mana dipengaruhi oleh dimensi vertikal manusia dengan penciptanya. Definisi tersebut tidak jauh berbeda dengan defmisi aksioma pertama yaitu unity (tawhid). Mohammed (2007) menjelaskan,

"The axiom of responsibility, smilar to the other three axioms discussed earlier, is significant for Islamic banks. All research participants mentioned that it is the responsibility of every 
person-individually and organizations-collectively to be socially responsible..."

OSeorang Muslim yang taat percaya bahwa, untuk mendapatkan kasih sayang dari Allah SWT ia harus mengikuti perintah Allah dan bertanggung jawab sepenuhnya atas segala tindakannya selama di bumi.

Tiga kategori penting dalam aksioma ini, yakni:

a. Accountability. Kesuksesan suatu bisnis tergantung pada ketaatan para pelaku terhadap ajaran-ajaran Islam, yang pada akhirnya akan berujung pada pertanggungjawaban mereka kepada Allah.

b. Management decisions of accountability based on Shariah. Islam melarang keras adanya praktik ketidakadilan dalam bentuk apa pun. Suatu bisnis, dalam praktiknya sangat riskan terjadi ketidakadilan, baik sesama pelaku bisnis maupun para pemegang kepentingan. Idealnya, keputusan manajemen yang diambil haruslah menguntungkan segala pihak dengan tetap memegang prinsip-prinsip syariah.

c. Fulfilling the responsibility as an organizations towards society. Merupakan dua tujuan utarna yang harus mampu diraih oleh suatu bisnis yang dijalankan oleh seorang pebisnis Muslim. Dua tujuan tersebut adalah tercapainya keuntungan bisnis tanpa mengesampingkan tanggung jawab sosial yang ada. 


\section{B. ETIKA BERBISNIS}

1. Definisi Etika dan Bisnis

Etika adalah seperangkat prinsip moral yang memungk'mkan seseorang untuk membedakan antara hal hal mana yang baik dan mana yang buruk. Istilah etika sering dihubungkan dengan moralitas. Moralitas merupakan unsur penting dalam setiap perilaku seseorang, tidak akan ada perilaku positif jika tidak ada etika yang melandasinya. Etika mempertahankan perilaku agar mengarah/menuju sikap yang baik. (Azmi dalam Hashim, 2012).

Bisnis dapat didefinisikan sebagai suatu kegiatan/aktivitas yang sah yang dilakukan untuk tujuan mendapatkan keuntungan. Kegiatan ilegal atau melanggar hukum tidak dapat disebut sebagai bisnis (Hashim, 2012). Kegiatan bisnis meliputi produksi, distribusi, dan hal lain yang menyangkut penciptaan, penjualan, dan pemasaran barang dan jasa. "Most people think that business has nothing to do with ethics but it business ignored the ethical standard will loose its image and not be able to survive" (Tufail dalam Hashim, 2012). Etika bisnis merupakan perangkat penting dalam bertransaksi yang sangat dikedepankan dalam Islam demi terciptanya win-win bagi pelanggan maupun perusahaan.

2. Nilai-nilai Islam dalam Bisnis

Banyak yang beranggapan bahwa ekonomi Islam tidak jauh berbeda dengan ekonomi konvensional. Ekonomi Islam tidak lebih dari ilmu konvensional yang dibalut dengan 
nilai-nilai Islam. Satu hal yang sangat membedakan ekonomi konvensional dari ekonomi Islam yakni ekonomi Islam adalah ilmu yang berasal dari God's theory (teori Allah), sedangkan ekonomi konvensional merupakan human's theory. Oleh karena ekonomi konvensional berasal dari teori yang dibuat manusia, maka teori-teori yang ada selalu berat sebelah atau memihak pihak tertentu. Ekonomi Islam secara jelas mengatur hubungan antarmanusia (tidak terkecuali dalam bermuamalah), di mana Allah sebagai pengawais di dalamnya. Selain empat aksioma (unity, equilibrium, free will, dan responsibility) yang telah dijelaskan pada sub bab'sebelumnya, berikut ini adalah nilai-nilai Islam yang juga perlu diterapkan dalam berbisnis, yang bertujuan untuk mewujudkan masyarakat yang adil, bertanggung jawab, dan jujur (Alserhan (2011):

a. Larangan suap (risywah). Tindakan suap menyuap, dalam Islam, sama dengan tindakan korupsi, dan sangat dilarang. Pelarangan ini berlaku bagi semua yang terlibat, mulai dari yang menawarkan, yang memberi, yang mengantarkan (perantara), sampai yang menerima. Rasulullah bersabda, 'Allah mengutuk orang yang memberi suap dan orang yang menerima suap serta séseorang yang menjadi perantara keduanya."

b. Larangan penipuan dan kecurangan. Islam menekankan pentingnya kejujuran di antara sesama. Islam melarang umat Muslim mendapatkan keuntungan dari hasil merugikan (menipu dan 
berbohong) orang lain. Seorang penjual tidak boleh melebih-lebihkan atau berbohong mengenai barang/jasa yang dijualnya. Allah berfirman : "Dan Syu'aib berkata: 'Hai kaumku, cukupkanlah takaran dan timbangan dengan adil, dan janganlah kamu merugikan manusia terhadap hak-hak mereka dan janganlah kamu membuat kejahatan di muka bumi dengan membuat kerusakan." (QS. Huud (I I): $85)^{\prime \prime}$

c. Larangan diskriminasi. Diskriminasi adalah suatu bentuk ketidakadilan atas pihak tertentu. Allah membedakan manusia satu dengan manusia yang lainnya bukan dari kekuasaan/kekuatan yang dimiliki manusia itu, melainkan dari amal ibadah dan ketaatannya kepada Allah.

d. Adanya tanggung jawab sosial. Setiap manusia dimuka bumi diberikan tugas oleh Allah untuk hidup, bermanfaat, dan bertanggung jawab, tidak hanya untuk kepentingan diri sendiri tetapi juga orang lain. Manusia diciptakan sebagai makhluk sosiaL, yang hidup berdampingan, dan saling tolong-menolong satu sama lain. Setiap pekerjaan yang dilakukan mengandung tanggung jawab sosial yang harus dilaksanakan. Contohnya dalam sebuah bisnis, Islam menekankan pentingnya memenuhi kewajiban kontrak dengan karyawan, mitra, pemasok atau klien. Kontrak yang dijanjikan tersebut harus jelas tertulis untuk melindungi hak-hak berbagai pihak yang 
terlibat, sehingga dapat mengurangi risiko terjadinya konflik dan menjamin kepatuhan.

e. Larangan pengambilan bunga. Islam sangat tegas melarang semua transaksi berbasis bunga. Sama dengan tindakan suap menyuap, pelarangan tindakan ini berlaku mulai dari yang membayar hingga yang menerima bunga. Pelarangan pengambilan bunga ini juga tidak hanya sebatas pada umat Muslim saja, tetapi juga non-Muslim. Allah berfirman dalam surah al-Baqarah (2) ayat 256:

"Allah memusnahkan riba dan menyuburkan sedekah. Dan Allah tidak menyukai setiap orang yang tetap dalam kekafiran, dan selalu berbuat dosa".

f. Larangan mendapatkan penghasilan dan kegiatan yang dilarang Islam. Penghasilan yang dilarang dalam Islam adalah penghasilan yang berasal dari perjudian, lotre, dan produksi, penjualan, dan distribusi barangbarang yang diharamkan dalam Islam seperti alkohol.

g. Larangan penimbunan dan pemborosan. Ada dua jems penimbunan yang sering terjadi di masyarakat; penimbunan barang dan penimbunan uang. Keduanya samasama dikutuk dalam Islam. Penimbunan jenis apa pun akan mengakibatkan scarcity (kelangkaan) yang akhirnya akan berdampak pada kenaikan harga. Islam mendorong penguasaan harta yang wajar dan tidak berlebihan, serta pengeluaran yang sepantasnya. Pada hari kiamat, manusia akan berdiri dihadapan Allah untuk mempertanggung jawabkan segala tindakannya, termasuk penggunaan harta 
selama ia hidup. Manusia harus berhati-hati dan sangat tidak dianjurkan untuk berperilaku boros. Allah berflrman yang artinya: " (yaitu) orang orang yang kikir, dan menyuruh orang lain berbuat kikir, dan menyembunyikan karunia Allah yang telah diberikanNya kepada mereka. Dan Kami telah menyediakan untuk orangorang kafir siksa yang menghinakan. Dan (juga) orang-orang yang menafkahkan harta-harta mereka karena riya kepada manasia dan orang-orang yang tidak beriman kepada Allah dan kepada hari kiamat. Barangsiapa yang mengambil jalan syaitan itu menjadi temannya, maka syaitan itu adalah teman yang seburuk-buruknya. (QS. an-Nisaa' (4): 37-38)"

h. Pembayaran zakat, Infak, dun sedekah. Setiap Muslim yang memiliki kekayaan berlebih wajib mengeluarkan 2,5 persen dari harta mereka untuk setiap Muslim yang miskin. Sementara itu, hukum infak dan sedekah adalah sunnah. Tujuan dari pengeluaran zakat, Infak, dan sedekah adalah untuk memastikan bahwa kebutuhan orang-orang miskin terpenuhi. Kekayaan seseorang tidak akan habis jika dikeluarkan untuk beramal, bahkan Allah menjamin penggantian yang berlipat ganda atas harta seseorang yang dengan ikhlas mengeluarkan hartanya untuk membantu mengangkat derajat orang miskin.

i. Kebersihan. Kebersihan merupakan sebagian dari iman. Kebersihan dalam berbisnis tidak hanya diaplikasikan pada bagian pelayanan pelanggan saja, 
tetapi juga bagian operasional, seperti pabrik produksi dan tempat penyimpanan.

\section{Etika dalam Kehidupan (Bisnis)}

Saat ini, krisis etika sangat jelas terjadi di segala aspek kehidupan manusia. Sektor swasta maupun publik, seperti keuangan, perbankan, bursa efek, jasa, manufaktur, manajemen, periklanan, politik. pemerintahan dirasa jauh dari penerapan etika dalam praktiknya. Hashim (2012) memaparkan beberapa aktivitas bisnis yang ilegal dan dilarang dalam Islam dan masih banyak ditemukan saat ini: (a) melakukan penipuan dalam urusan bisnis; (b) penjual yang sering melakukan sumpah palsu agar pembeli percaya bahwa produk yang dijualnya berkualitas; (c) menampilkan hal-hal yang tidak pada kenyataannya (misalnya, penjual membuat janji, tetapi tidak dipenuhi); (d) penimbunan yang bertujuan mendapatkan keuntungan yang tinggi (kegiatan spekulatit); (e) penerapan bunga/riba pada setiap transaksi yang dilakukan; (f) diskriminasi harga; (g) jual beli daging hewan haram; (h) jual beli senjata yang menyebabkan kehancuran manusia; (i) jual beli minuman keras; (j) menyimpan bahan makanan untuk waktu mendatang dan kemudian menjual dengan harapan memperoleh keuntungan; (k) praktik bisnis penipuan; (1) black marketing, menjual barang dengan kondisi buruk dan atau barang curian; dan (m) transaksi yang melibatkan ketidakpastian. 
Contoh nyata lain yang sering terjadi adalah ketidakjujuran dalam praktik pasar modal. Seorang investor biasanya menginginkan informasi yang jelas mengenai perusahaan-perusahaan yang bergabung dalam bursa efek sebelum memutuskan untuk berinvestasi. Hal tersebut merupakan hak investor dan diatur dalam Undang-Undang Pasar Modal. Namun pada kenyataannya, masih banyak yang belum diatur dan berpotensi merugikan pihak investor, seperti penulisan laporan keuangan yang disajikan oleh emiten, di mana hanya sekadar memenuhi apa yang tertuang dalam Undang-Undang Pasar Modal. Seharusnya, emiten sebagai pengelola dana harus mengedepankan kejujuran (keterbukaan) dan mengutamakan kepentingan investor terlepas dari aturan yang ada dalam Undang-Undang Pasar Modal. Pasar bebas dan mekanisme pelaksanaannya dimungkinkan juga menjadi sumber permasalahan yang disebabkan karena dalam praktiknya jauh dari nilai etika. Pembelajaran, pemahaman dan kepedulian mengenai moral dan etika ini sudah seharusnya dilakukan untuk mewujudkan keadilan di antara semua pihak.

Etika dalam pemasaran syariah bukan suatu hal yang dapat ditawar. Menurut Alom dan Haque (2011), penerapan etika memastikan suatu perusahaan akan membawa keuntungan bagi semua pemangku kepentingan. Menurutnya, suatu bisnis tidak boleh hanya mementingkan dan mengejar maksimalisasi keuntungan 
saja, tanpa mengikuti petunjuk agama. Adanya etika akan memastikan terbentuknya keseimbangan antara dimensi material dan dimensi spiritual, serta memaksimalkan kesejahteraan dunia (seperti membangun persaudaraan di antara semua pemangku kepentingan serta keadilan sosial ekonomi) dan akhirat. Haqqi (2009) berpendapat,

"The islamic law of transaction as well as the whole Islamic legal sistem has its set of requisites, prohibitions and ethics that cannot be easily defeated by the more of two persons' wills. Fairness and good measure in transactions are given more consideration than freedom of contract and that is not surprising in a sistem of law arising out of a religion that is intended to govern the life of the believers in this world in preparation for the world here after. "

Pernyataan di atas menekankan bahwa hukum transaksi dalam Islam secara keseluruhan terdiri dari syarat, larangan, dan etika yang tidak dapat dengan mudah dihilangkan atau dikesampingkan hanya dengan kehendak dua (lebih) orang yang melakukan transaksi. Adanya batasan dan aturan dalam suatu transaksi lebih diutamakan daripada pelaksanaan kebebasan berkontrak, di mana kebebasan individu menjadi ciri khasnya.

Apabila tidak ada aturan yang membatasi manusia dalam bertransaksi atau aktivitas lainnya, maka manusia tidak akan 
mampu menghadapi ujian kchidupan. Menurut Alserhan (2011), ujian kehidupan tersebut adalah:

a. Temptations, yaitu godaan-godaan yang dapat merasuki manusia, misalnya membuat keuntungan melalui caracara yang fasik seperti meminjamkan uang dengan tambahan bunga atau melakukan promosi produk dengan cara yang berlebihan atau tidak sesuai dengan kondisi produk yang sebenamya. Padahal, dalam Islam ditegaskan bahwa suatu produksi mulai dari proses pembuatan produk, pengiriman, sampai pembelian/penggunaan produk oleh konsumen, tidak boleh merugikan pihak manapun. Hadis Nabi riwayat Ibnu Majah dari 'Ubadah bin Shamit, riwayat Ahmad dari Ibnu 'Abbas, dan Malik dari Yahya: "Tidak boleh membahayakan (merugikan) dirt sendiri dan tidak boleh.

b. Hardships, adalah suatu kondisi dimana seseorang dalam titik terlemahnya, seperti tidak tercukupinya kenbutuhan hidup sehari-harinya, tidak mampu menafkahi diri sendiri dan keluarganya, seorang pemilik bisnis yang kekurangan dana untuk biaya produksinya atau untuk ekspansi usahanya. Dalam hal ini, harus menjauhkan diri dari penggunaan produk keuangan berbasis bunga. Seorang pengusaha yang mengalami kesulitan harus bekerja lenih keras dan melakukan inovasi-inovasi produk yang sesuai dengan kebutuhan dan minat masyarakat luas saat itu.

\section{IMPLEMENTASI BAURAN PEMASARAN SYARIAH}

Pemasaran menjadi salah satu pendukung tercapai/tidaknya tujuan utama berbisnis, yaitu profit yang 
tinggi. Namun, perlu diingat bahwa profit yang tinggi bukan satu-satunya tujuan dalam bisnis islam. Rasullulah saw. Memberi contoh kepada umatnya bahwa menjalin dan menjaga silaturahmi dalam berdagang lebih penting daripada mendapat keuntungan semata. Pemasaran merupakan bagian dari muamalah yang dibolehkan dalam islam, sepanjang dalam proses transaksinya tidak ada ketentuan-ketentuan syariah melarangnya. Oleh karena itu, terdapat cabang ilmu ekonomi islam yakni pemasaran syariah yang mempelajari tentang proses penciptaan, penawaran, dan perubahan values dari seorang seller/ marketer kepada sejumlah buyers yang dalam keseluruhan prosesnya sesuai dengan akad dan prinsip-prinsip muamalah islam.

Demi tercapainya tujuan pemasaran diperlukan beberapa variabel pemasaran yang dapat dikendalikan dan digunakan oleh seorang pelaku bisnis atau badab usaha. Variabel pemasaran yang dimaksud disebut bauran pemasaran (marketing mix). Bauran pemasaran syariah tidak jauh berbeda dengan bauran pemasaran pada umunya, terdiri dari empat komponen: produk, harga, distribusi, dan promosi. Perbedaannya hanya terletak pada implementasinya; karena setiap variabel dalam bauran pemsaran syariah pelaksanaannya didasarkan atas prespektif Islam. Berikut adalah penjelasan keempat komponen bauran pemasaran dalam prespektif Islam disadur dari Bahari, dkk (tanpa tahun).

\section{Product}

Suatu produk/jasa merupakan variabel bauran pemasaran yang pertama yang seharusnya menjadi fokus utama para pebisnis. Seorang pebisnis Muslim harus mampu membaca 
kondisi pasar dan menciptakan produk yang dibutuhkan pasar tersebut (who's the buyer). Hal itulah yang menjadi salah satu pembeda antara strategi pemasaran syariah dengan pemasaran konvensional. Strategi pemasaran konvensional diras hanya sekedar berlomba-lomba menciptakan dan menawarkan produk baru tanpa melihat kebutuhan pasar pada saat itu. Selain itu, halalnya suatu produk/jasa yang ditawarkan pun menjadi keunggulan tersendiri dalam bauran pemasaran yariah. Secara umum, semua praktik tindakan Muslim diklasifikasikan berdasarkan kategori berikut (Alserhan, 2011):

a. Halal (permissible). Kategori halal memiliki tiga tingkatan:

1) Wajib (duty). Seorang Muslim yang tidak melakukan suatu hal yang sifatnya wajib akan berdosa. Tanpa melakukan hal-hal yang bersifat wajib ini, dapat dikatakan suatu perusahaan berarti tidak memenuhi shariah-complaint. Implikasinya: perusahaan harus melakukan hal-hal yang sifatnya wajib tersebut. Salah satu contohnya adalah mengedepankan sikap jujur dan transparansi.

2) Mandub (likeable). Sifatnya adalah boleh dan tidak berdosa jika ditinggalkan. Mandub dapat disebut sebagai "supplementary halal. Implikasinya adalah jika memungkinkan perusahaan dapat melakukan hal-hal yang sifatnya mandub tersebut. Contohnya adalah membantu dan berusaha bekerja keras.

3) Makruh (despised). Hal-hal yang makruh berarti tidak disukai atau dianjurkan oleh agama, dan 
biasanya dipilih sebagai jalan/solusi terakhir. Implikasi: hindari jika memungkinkan. Salah satu contoh umum hal yang bersifat makruh adalah perceraian.

b. Mushtabeh (doubted). Seorang M uslim harus menahan diri dari tindakan atau hal yang meragukan. Hal yang meragukan berarti statusnya tidak jelas apakah hal tersebut dibolehkan atau tidak dalam islam. Pebisnis harus menahan diri dari keterlibatannya dalam kegiatan yang meragukan agar tidak dipandang tidak bermoral oleh pesaing dan terutama oleh pelanggan.

c. Haram (not pemissible). Segala tindakan yang sangat jelas dilarang oleh Islam, baik secara eksplisit maupun implisit. Mereka yang terlibat dalam tindakan haram ini akan berdosa.

Ketika seorang pebisnis mengutamakan kebutuhan pasar dalam menciptakan produk, maka win-win condition akan terbentuk; kebutuhan konsumen akan terpenuhi, dan keuntungan yang besar akan dialami oleh pebisnis. Disamping itu, adanya keadilan dalam pendistribusian produk sangat penting untuk menghindari inflasi harga akibat adanya penimbunan yang dilakukan oleh beberapa pihak.

Bahari, dkk (tanpa tahun) lebih lanjut mengklasifikasikan hal-hal penting yang terkandung dalam pengimpletasian bauran pemasaran ini.

a. Karakteristik Produk dalam Pemasaran Syariah 
Pelaksanaan pemasaran syariah tidak dapat dihindari akan berbeda antar pelaku bisnis, akan tetapi prinsip-prinsip yang diterapkan harus sejalan dengan Al-Qur'an dan Hadis. Penyerahan total kepada Allah SWT melekat pada praktik pemasaran syariah, artinya semua aspek pemasaran, mulai dari perencanaan hingga pasca penjualan, harus pararel dengan prinsip/ajaran Islam. Dengan kata lain, apa pun kegiatan pemasaran harus dilakukan dalam batas-batas etika yang ditetapka oleh Islam. Ada beberapa aspek pemasaran syariah yang harus benar-benar diperhatikan ketika berkaitan dengan produk:

\section{1) Realistis}

Seiring dengan pesatnya kemajuan dibidang teknologi informasi dan globalisasi dalam sistem keuangan, serta inovasi finansial, seorang pebisnis/pemasar harus kreatif dalam menciptakan sebuah terobosan. Sebagai contoh, jika pebisnis berniat untuk menjual suatu produk yang mahal, maka ia harus menyediakan pilihan pembelian kepada target konsumennya yang ingin membeli produknya. Pembelian produk secara kredit dapat menjadi salah satu pilihan, selain membeli secara tunai. Hal ini penting bagi pemasar Islam untuk memahami konsep ini karena akan meningkatkan semangat dalam memasarkan produk mereka.

2) Transparansi

Nabi Muhammad SAW bersabda: “Dikisahkan Hakim bin Hizam: Rasullulah berkata, 'Penjual dan pembeli memiliki hal untuk menyimpan atau mengembalikan barang selama mereka belum berpisah, atau sampai mereka berpisah; dan jika kedua pihak berbicara kebenaran dan 
menggambarkan cacat dan kualitas (barang), maka mereka akan diberkati dalam transaksi mereka, dan jika mereka berbohong atau menyembunyikan sesuatu, maka berkekahan transaksi mereka akan hilang'." Hadis tersebut secara jelas menegaskan bahwa ketidakjujuran dan menutupi kekurangan dalam memasarkan produk/jasa dapat menjadi penghalang bagi konsumen dan produsen dari bahaya dunia maupun akhirat.

\section{b. Elemen Fundamental Produk dalam Strategi Pemasaran Syariah}

Menurut Kotler dan Amstrong (2010), "Companies must position their products so that the products could be deemed valuabele from the customers' perspective," artinya perusahaan harus memosisikan atau memastikan bahwa produk/jasa yang mereka jual dianggap berharga dari sudut pandang pelanggan. Telah disebutkan sebelumnya bahwa, kebutuhan pasar menjadi petunjuk utama bagi para calon pedagang untuk menyediakan produk/jasa yang sesuai dengan kebutuhan pasar tersebut, sehingga dapat bersaing dengan pedagang lainnya. Keunikan juga menjadi salah satu ciri yang membuat produk/jasa yang ditawarkan bernilai tinggi di mata para (calon) pembeli.

Selama masa hidupnya, Nabi Muhammad SAW memosisikan dirinya sebagai pedagang yang jujur. Sifat itu menjadi "daya tarik" tersendiri bagi para pelanggannya, bahkan para pesaingnya. Namun, tidak berarti bahwa Nabi Muhammad SAW tidak berpikir tentang kualitas produkproduknya. Gunara dan Sudibyo (2007) menyampaikan bahwa, 
"Positioning yang dilakukan Nabi Muhammad SAW bukan pada produk yang dijual karena memang penggunaan merek belum merupakan hal yang lazim dilakukan. Merek produk yang tercipta pada saat itu hanyalah berdasarkan lokasi geografis seperti sutra di Cina. Sehingga, positioning yang ada lebih condong pada pembentukan personal branding diri Nabi Muhammad SAW. Reputasi Nabi Muhammad SAW sebagai pedagang yang jujur dan terpercaya telah terbina dengan baik sejak usia muda baik di kalangan pengusaha saat itu sampai ke kalangan investor yang merupakan orang-orang kaya di kota Mekkah. Beliau selalu memperlihatkan rasa tanggung jawab dan integritas yang besar dalam berurusan dengan orang lain. Positioning itu lah yang secara terus menerus ditanamkan oleh Nabi Muhammad SAW, sehingga mengakar dengan baik dalam benak para pengusaha. Di samping itu, beliau juga mampu menempatkan dirinya sesuai dengan lingkunngan di mana dia berada."

Dengan kepribadian Nabi Muhammad SAW yang mengutamakan kejujuran, transparansi, tanggung jawab, terbentuklah diferensiasi dalam penawaran yang pada akhirnya menjadi unsur utama dalam pemasaran syariah. Keunggulan dari pebisnis Muslim jika dibandingkan dengan pebisnis non-Muslim adalah kehalalan produk yang dijual. Melai dari pemilihan bahan-bahan yang dipakai, proses pembuatan, sampai dengan pengepasan produk. Produk halal berarti produk yang telah dinyatakan halal sesuai 
dengan syariah. Kewajiban dalam mengonsumsi produk halal membuat para pebisnis global, tidak terkecuali pebisnis nonMuslim, berusaha menciptakan produk yang halal, mengingat jumlah penduduk terbanyak di dunia, terutama di Indonesia. Indonesia memiliki lembaga yang berwenang dalam menentukan halal tidaknya suatu produk. Lembaga tersebut adalah LPPOM MUI (Lembaga Pengawasan Pangan Obat dan Makanan Majelis ulama Indonesia). Produk yang dinyatakan memenuhi syarat halal akan mendapat sertifikasi kehalalan.

Peraturan dan sertifikasi halal produk membentuk mekanisme yang baik untuk membantu umat Islam dalam memenuhi komitmen dan ketaatan mereka terhadap ajaran Islam di antara pesatnya perkembangan teknologi dan munculnya berbagai jenis produk dan jasa di dunia saat ini. Ismaeel dan Blaim (2012) mengatakan, "Halal business pratices vary from one country and industry to another, this variation is due to the differences in the reliability and functionality of institutions and governance structure in those countries and industries". la menjelaskan bahwa regulasi dan sertifikasi halal suatu produk dapat dikembangkan dengan cara mengintegrasikan kegiatan CSR dengan etika dan rasa tangung jawab menjadi suatu kesatuan, sehingga menurutnya,

"By doing this, the Halal business can become a role model for modern business development and contribute to more responsible business praticies ... Applying CSR praticies can help to integrate more criteria and herewith further develop a responsible Halal business. Islamic business ethics and CSR 
by nature have similiar elements; both praticies are built on strong values, responsible behavior and sustainability. Both subjects are based on the ethical permissibility of things and behaviors. Therefore, CSR has good chances to be successfully integrated in Halal business pratices and contribute to a successful future movement of Halal."

Sertifikasi kehalalan sebagian besar masih terfokus terhadap produk yang dijual. Perlu diingat bahwa pertimbangan halal tidaknya suatu bisnis, bukan hanya ditentukan dari produk yang dijualnya saja, tetapi kehalalan bisnis yang bersifat holistic (secara menyeluruh). Ismaeel dan Blaim (2012) menciptakan sebuah pendekatan baru dalam rangka mengintegrasikan CSR dan etika untuk memperbaiki standar peraturan dan sertifikasi halal, yang tidak hanya didasarkan pada produk jasa. Pendekatan itu disebut multilevel approach.

Multi-level approach adalah pendekatan yang berbasis pada informasi produk dan bisnis secara keseluruhan yang disediakan oleh perusahaan meliputi kriteria etika dan tanggung jawab (kewajiban) perusahaan, di samping aturan standar dasar halal. Badan regulasi dan sertifikasi halal di setiap negara mempunyai standar yang berbeda dalam penetapan produk halal. Pendekatan multi-level approach ini akan menciptakan standar baru tersebut dapat berfokus pada etika dan keseluruhan praktik bisnis.

\section{Price}

Harga adalah suatu nilai tukar yang dapat disamakan dengan uang atau barang lain untuk manfaat yang diperoleh dari suatu produk/jasa bagi seseorang atau kelompok pada 
waktu cerminan nilai jual atas produk/jasa yang telah melalui proses produksi. Penetapan harga sepenuhnya ditentukan oleh penjual. Hal itu menjadikan komponen bauran pemasaran syariah ini menjadi sumber penghasilan dan keuntungan bagi penjual. Pemasaran syariah mengatur penetapan harga yang sesuai dengan prespektif Islam. Aturan penetapan harga tersebut adalah sebagai berikut:

a. Seorang penjual dilarang menjual pada harga yang lebih tinggi daripada biaya input dan margin keuntungan. Tindakan mendapat keuntungan yang tidak wajar melaluyi penetapan harga yang tinggi tanpa adanya perubahan kualitas yang lebih baik dan/atau penambahan kuantitas, sama saja dengan maisir atau perjudian. Maisir dalam bahasa arab secara harfiah adalah memperoleh sesuatu dengan mudah tanpa kerja keras atau mendapat keuntungan tanoa bekerja. Maisir sangat dilarang dalam Islam.

b. Praktik diskriminasi harga juga dilarang dalam Islam. Penjual tidak diperbolehkan menetapkan harga yang berbeda kepada dua orang pembeli atau lebih atas barang yang sama. Perlakuan semacam itu disebut riba (Saeed dan Sohail, 2001).

c. Menipulasi harga tidak dibenarkan dalam sudut pandang pemasaran syariah. Salah saru contoh manipulasi harga adalah pemilik berpura-pura menjadi "pembeli" atas barang yang dijualnya dengan cara memuji-muji barang miliknya, sehingga pembeli lain percaya dan rela membayar dengan harga tinggi. Penimbunan produk dan pembatasan produksi yang mengakibatkan kenaikan 
harga sangat dilarang dalam Islam. Namun demikian, Islam tidak melarang adanya pembatasan produksi dan kontrol harga ketika menyangkut tujuan memenuhi kebutuhan pasar. Contoh praktik saat ini yaitu penetapan harga karena faktor tanggal oleh maskapai penerbangan, hotel dan beberapa industri lain sebagai strategi penjualan kepada pelanggan.

d. Perbedaan tingkat harga di antara sesama penjual dapat memengaruhi kondisi pasar secara menyeluruh. Pada kondisi pasar persaingan sempurna dimana barang yang dijual bersifat homogen dengan banyak penjual dan pembeli, harga dengan sendiri akan terbentuk melalui mekanisme pasar. Ketika ada salah satu penjual dalam pasar tersebut menaikkan harga produknya di atas harga pasar atau sebaliknya, ia menjual produknya dengan harga dibawah harga pasar maka yang akan terjadi adalah distorsi pasar. Distorsi pasar akan memacu kondisi ekonomi menjadi tidak efisien sehingga mengganggu agen ekonomi dalam memaksimalkan kesejahteraan sosial dengan maksud memaksimalkan kesahteraan mereka sendiri.

\section{Place}

Tempat atau distribusi diakui sebagai salah satu kunci sukses dalam strategi pemasaran yang efektif. Tempat yang strategis dan mudah dijangkau oleh pelanggan dalam jual beli merupakan representasi dari prinsip dasar Islam bahwa manusia sebagai wakil Allah SWT di muka bumi harus mengelola sumber daya yang ada dengan cara yang adil. Pada awal bahasan telah dijelaskan bahwa tindakan 
penimbunan dan monopoli untuk mendominasi saluran distribusi dengan niat untuk mendapatkan keuntungan sangat dilarang dalam Islam.

Pemerataan atau keadilan distribusi produk dalam praktiknya adalah menjaga kelancaran saluran distribusi yang ada untuk memastikan bahwa produk tersebut sampai kepada pelanggan terakhir dan dapat memenuhi kebutuhan mereka. Hal tersebut berlaku pula atas reseller (penjual yang menjual barang milik agen lain dengan margin keuntungan tertentu). Tempat di mana produsen rnenjual barangnya harus mudah dijangkau oleh pelanggan. Konteks "mudah dijangkau" dalam hal ini tidak hanya secara fisik saja, akan tetapi dalam hal kenyamanan, kemudahan memperoleh informasi, dan adanya fasilitas transportasi yang aman dalam pengiriman barang ke tempat pelanggan.

Tidak dapat dipungkiri bahwa peningkatan kualitas pelayanan distribusi akan menambah beban biaya produksi, tetapi hal tersebut akan diikuti oleh kepuasan, kepercayaan, dan loyalitas pelanggan. Kepuasan, kepercayaan dan loyalitas pelanggan pada akhirnya akan meningkatkan jumlah unit penjualan yang secara otomatis meningkatkan laba penjualan.

\section{Promotion}

Dalam era bisnis yang kompetitif saat ini, sangat tidak mudah menjual sesuatu tanpa adanya promosi. Pelanggan tidak hanya ingin membeli produk/jasa, tetapi juga ingin mendapatkan manfaat yang menarik dan unik dari produk/jasa yang ditawarkan (Rahman, dkk, 2014). Tidak 
dapat dimungkiri bahwa promosi penjualan meningkatkan penerimaan (keuntungan) dan membuka peluang bisnis untuk ekspansi ke pasar potensial. Namun, untuk mendapatkan semua itu banyak para pelaku bisnis yang masih menyimpang dari moral, etika dan aturan-aturan yang ada, bahkan pelaku bisnis Muslim sekali pun. Rahman, dkk (2014) berpendapat bahwa mereka lebih memuji produk mereka, memberikan janji palsu tentang manfaat produk, dan tindakan promosi lain yang melanggar ajaran Islam.

Pada dasarnya, promosi dalam pemasaran syan'ah harus beretika dan terbuka. Kebenaran dalam setiap informasi tentang produk yang dipasarkan adalah inti dari promosi pemasaran syariah. Perilaku tersebut didasarkan pada ajaran Al-Quran dan Hadis di mana segala sesuatu yang dikerjakan oleh seorang Muslim pasti bersifat vertikal yaitu, ada pertanggungjawaban perilaku manusia kepada Allah SWT. Oleh karenanya, penjual dan/ atau pemasar berkewajiban untuk mengungkapkan semua informasi, termasuk kerusakan barang kepada pembeli yang tidak dapat dilihat secara kasat mata. Pernyataan palsu, melebihlebihkan, dan menutup-nutupi ialah perilaku yang dilarang keras dalam proses penjualan.

Saat ini, sangat sedikit penjual yang menjunjung tinggi kejujuran mengenai produk yang mereka jual, dan akhirnya pembelilah yang merugi. Pembeli mendapatkan barang yang tidak sesuai dengan kualitas barang yang dijanjikan oleh si penjual. Dalam jangka pendek mungkin hal tersebut tidak dirasa dampaknya oleh penjual yang 
bersangkutan, namun dalam jangka panjang, ketidakjujuran yang terus menerus dilakukan selama berpromosi akan berdampak pada berkurangnya pelanggan dan tidak menutup kemungkinan adanya tuntutan dari para pelanggan yang merasa dibohongi dan dirugikan (Rahman, dkk, 2014).

Salah satu bentuk etika dalam berpromosi lainnya adalah tidak melakukan promosi manipulatif, di mana penjual (pemasar) membujuk pelanggan dengan memanfaatkan kebutuhan emosional mereka, bukan dengan kebutuhan rasional. Perilaku promosi manipulatif ini menggunakan naluri dasar pelanggan sehingga muncul perilaku impulsif terhadap produk tertentu, yang mana kondisi tersebut menguntungkan pihak penjual dan pemasar karena mendapat penjualan (keuntungan) yang lebih baik.

Abdullah dan Ahmad (2010, dalam Bahari, dkk, Tanpa Tahun) merangkum enam prinsip dalam menerapkan kegiatan pemasaran. Prinsip-prinsip tersebut adalah kebenaran, kepercayaan, ketulusan, persaudaraan, ilmu pengetahuan dan teknologi, dan keadilan. Apabila keenam prinsip tersebut diaplikasikan pada komponen promosi dan komponen bauran pemasaran syariah lainnya maka, tujuan perusahaan akan dengan mudah tercapai. Kegiatan produksi, yang dimulai dari perencanaan, penetapan harga dan strategi distribusi, dan promosi yang digunakan wajib sesuai dengan Al-Quran dan Hadis.

Iklan adalah suatu media promosi bagi perusahaan untuk menginformasikan keunikan dan kelebihan 
(keunggulan) produk yang dijualnya dibanding produk milik pesaing. Etika dalarn beriklan adalah suatu perilaku (sikap) dalarn mempromosikan sesuatu dengan memasukkan unsur spiritual, realistis, kreativitas, tidak terlalu kaku, dan tidak keluar dari hukum Islam yang berlaku. Iklan yang beretika merupakan ciri dari pemasaran syariah. Selain yang telah disebutkan pada poin sebelumnya, harus terhindar dari unsur seksual, daya tarik emosional, mengeksploitasi perempuan dalam iklan, penggunaan fantasi yang berlebihan, penggunaan penelitian palsu yang dibuat untuk mempromosikan suatu produk yang menyebabkan kebodohan dan/ atau mendorong pemborosan, dan penggunaan bahasa dan perilaku yang sifatnya sugestif.

Rahman, dkk (2014) berpendapat bahwa Islam memberikan aturan yang ketat dalam dunia periklanan. Lebih lanjut, ia menjelaskan bahwa perempuan tidak boleh digunakan sebagai objek produk untuk menarik konsumen. Hal tersebut disebabkan karena akan menciptakan daya tarik yang liar kepada lawan jenis. Islam membolehkan adanya perempuan dalam media promosi suatu bisnis asalkan perempuan tersebut menutup auratnya, karena jika tidak dikhawatirkan mendorong tindak kejahatan/perbuatan keji di masyarakat.

Saat ini, telah banyak produk yang diiklankan dengan cara yang unik dan bahkan menimbulkan kontroversi. Iklan kontrovesial tersebut misalnya, bersifat menyinggung seseorang atau suatu masyarakat sehingga menimbulkan ketidaksukaan di mata pelanggan (Akhter, 
dkk, 2011) mengklasifikasikan produk kontroversial dalam tiga kategori yaitu produk, layanan dan konsep. Produk mencakup produk alkohol (obat-obatan), rokok, pakaian dalam wanita dan lain-lain; layanan mencakup fasilitas aborsi, pelayanan operasi plastik tanpa ada alasan kesehatan, tes penyakit kelamin, dan lain-lain; konsep mencakup ide-ide politik, aksi terorisme, praktik-praktik seksual, prasangka atas agama tertentu, dan lain-lain.

Sebuah studi dilakukan Akhter, dkk (2011) berjudul Ethical Issues in Advertising in Pakistan: An Islamic Perspective, bertujuan untuk menyelidiki pengaruh persepsi agama konsumen, perbedaan gender, dan daya tarik iklan terhadap besarnya tingkat ojfensiveness yang muncul pada diri konsumen. Salah satu hasil penting dari penelitian ini adalah pemasar harus pintar dalam menggunakan daya tarik iklan suatu produk karena antara pelanggan laki-laki dan perempuan memiliki persepsi yang berbeda. Selain itu, hasil penelitian ini mengerucut pada dua poin penting lainnya, yakni:

\section{Implikasi Manajerial}

Satu hal yang sangat penting bagi organisasi-organisasi pemasaran di Pakistan dalam mempersiapkan dan mempromosikan sebuah produk tertentu untuk pelanggan mereka. Fakta yang didapat dari penelitian ini bahwa normanorma budaya dan nilai-nilai masyarakat memainkan peran penting dalam membentuk dan menentukan sikap (keputusan) pelanggan. Pemasar yang menggunakan bahasa tidak baik, visualisasi yang mengandung unsur seksual 
ternyata menimbulkan ojfensweness yang cukup tinggi dalam benak konsumen atas produk mereka.

2. Implikasi Sosial

Penelitian ini mengidentifikasi satu masalah penting yang menyangkut etika periklanan yang bertentangan dengan ajaran Islam dan memiliki dampak negatif terhadap pola pikir, serta perilaku generasi muda, yakni menempatkan mereka jauh dari nilai-nilai moral Islam. Masalah itu dapat berisiko dalam jangka panjang, karena akan timbul gaya hidup dan nilai-nilai budaya masyarakat yang mungkin tidak dapat diterima oleh syariah. Pemasar sebaiknya memasarkan produk dengan cara yang tidak bertentangan dengan norma-norma, nilai-nilai, etika dan persepsi agama pasar yang menjadi target mereka.

Adanya etika dalam dunia periklanan tidak hanya berakibat mendapatkan pengakuan dari pelanggan, tetapi juga disegani oleh pesaing. Beretika dalam beriklan, selain mendapat pengakuan mulai dari pelanggan hingga pesaing, juga mendapat popularitas/kesan tersendiri di hati pelanggan. ]ika penjual melakukan kegiatan promosi penjualan yang etis, maka dimungkinkan bisnisnya akan bertahan dalam jangka waktu lama, dan keuntungan yang didapat akan mengalami peningkatan. Jika para pemasar bercermin dari praktik Nabi Muhammad SAW. dan para sahabat, mengikuti prosedur penjualan dan promosi dengan sabar dan bermoral, maka mereka tidak perlu melakukan praktik yang tidak etis (Rahman, dkk, 2014). 


\section{STRATEGI PEMASARAN SYARIAH}

Ada tiga elemen yang menjadi strategi pemasaran syariah, yaitu diferensiasi, bauran pemasaran, dan penjualan :

\section{Diferensiasi}

Esensi dari diferensiasi adalah agar lebih dikenal sehingga menjadi identitas diri. Nabi Muhammad SAW memberitahu kepada setiap pelanggannya titik lemah dari produknya. Beliau tidak pernah menyembunyikan apa pun dari para pelanggannya, termasuk kekurangan produk yang dijualnya. Ada kewajiban moral yang diemban oleh Nabi Muhammad SAW untuk menginformasikan secara detail kepada para pelanggannya atas produk yang ditawarkan.

Pada kenyataannya, apa yang dilakukan Rasulullah SAW, tersebut cukup sulit dilakukan mengingat persaingan bisnis yang terjadi saat ini dirasa kurang mengedepankan honesty dan fairness. Saling menjatuhkan penjual lain, meniru produk lain, dan kurangnya transparansi atas produk yang dijual sepertinya telah menjadi budaya dalam dunia bisnis saat ini. Padahal, jika para pebisnis benar-benar menjadikan Rasulullah SAW sebagai panutan, baik dalam kehidupan sehari-hari maupun berbisnis, maka keberkahan akan datang dengan sendirinya.

Salah satu cara yang dapat ditempuh untuk mendapatkan sebuah diferensiasi adalah dengan mengintegrasikan konten (content), konteks (context), dan infrastruktur (infrastructure) yang dimiliki sehingga 
dapat menjadi sebuah nilai lebih yang dapat ditawarkan kepada pelanggan (Gunara dan Sudibyo, 2007).

\section{Bauran Pemasaran}

Bauran pemasaran umumnya terdiri dari empat komponen utama, .yakni produk, harga, distribusi, dan promosi. Komponen produk digambarkan dengan penjualan komoditas yang dibutuhkan oleh semua orang, berkualitas baik, dan bersifat tahan lama. Selain itu, terdapat ketentuan bahwa dilarang untuk menjual komoditas yang berkualitas rendah dan tinggi pada tempat yang sama. Oleh karena itu, dibutuhkan transparansi produk/jasa yang dijual agar para pelanggan dengan mudah membedakan kualitas produk kelas tinggi dan rendah. Komponen distribusi dan harga saling melengkapi satu sama lain. Islam melarang adanya praktik monopoli dalam suatu pasar. Adanya dominasi pihak tertentu yang mengatur saluran distribusi tidak dapat dimungkiri bertujuan untuk mengendalikan tingkat harga produk yang dijual. Komponen keempat adalah promosi. Suatu produk harus dikomunikasikan dalam batas-batas etika sehingga pelanggan tidak merasa tertipu. Pada akhirnya, Islam mengajarkan untuk mengutamakan kesepakatan dalam proses jual beli. Pemenuhan rukun dan syarat jual beli merupakan penentu dapat diterimanya proses jual-beli.

\section{Penjualan}

Rukun dan syarat jual beli harus ada dalam setiap transaksi jual beli agar terhindar dari kondisi yang merugikan salah satu pihak. Menurut Suhendi (2011), 
terdapat tiga rukun jual beli, antara lain: akad (ijab kabul), orang-orang yang berakad (penjual dan pembeli), dan ma'kud alaih (objek akad).

Akad ialah ikatan kata antara penjual dan pembeli. Jual beli belum dikatakan sah apabila belum adanya kerelaan (keridhaan) di antara kedua belah pihak. Dengan demikian, maka pembeli mempunyai hak untuk membatalkan atau melanjutkan proses negosiasi dengan penjual ketika ia merasa produk/jasa yang ditawarkan tidak sesuai dengan ekspektasinya. Kondisi tersebut mewajibkan penjual untuk menunggu proses negosiasi sampai benar-benar selesai, untuk kemudian dapat melakukan proses negosiasi dengan pembeli lainnya.

Rukun kedua yaitu adanya orang-orang yang berakad. Ada beberapa syarat yang harus dipenuhi bagi orang yang melakukan akad, antara lain: balig, berakal, dan mengerti. Rukun terakhir adalah objek akad. Penjual dilarang menjual sesuatu yang tidak jelas atau tidak ada. Objek akad haruslah barang yang dapat dipindahtangankan. Di samping itu, besaran barang yang ditransaksikan harus seakurat mungkin. ]ika berat barang tersebut adalah tiga kilogram, maka skala yang digunakan harus menunjukkan tiga kilogram, tidak boleh kurang atau lebih.

\section{E. KUALITAS PELAYANAN}

Pelanggan memegang peranan penting dalam dunia bisnis. Secara tidak langsung, seorang pelanggan dapat menjadi saluran pemasaran bagi suatu bisnis. Ketika pelanggan merasa 
puas atas pelayanan suatu produk/jasa, sangat dimungkinkan pelanggan tersebut "mempromosikan" secara sukarela produk/ jasa itu kepada orang-orang sekitarnya. Adanya sebuah rekomendasi positif dari suatu pelanggan kepada seorang atau beberapa calon pelanggan lainnya sudah pasti akan menguntungkan pihak penjual, karena calon pelanggan tersebut tidak perlu ragu lagi akan kualitas produk/jasa itu. Sebaliknya, apabila pelanggan tersebut merasa kurang puas, atau bahkan kecewa terhadap suatu produk/jasa, maka yang terjadi adalah kesediaan untuk menggunakan produk/jasa dari penjual itu akan hilang dan saluran promosi secara cuma-cuma kepada orang terdekat pun tidak akan terjadi.

Menurut Umar (2011), kepuasan konsumen adalah tingkat perasaan konsumen setelah membandingkan dengan harapannya. Seorang pelanggan jika merasa puas dengan nilai yang diberikan oleh produk atau j asa maka sangat besar kemungkinannya untuk menjadi pelanggan dalam waktu lama (Umar, 2011). Lebih lanjut, Umar (2011) menjelaskan bahwa ada dua macam jenis kepuasan, yaitu kepuasan fungsional dan kepuasan psikologikal. Kepuasan fungsional merupakan kepuasan yang diperoleh dari fungsi suatu produk yang dimanfaatkan, sedangkan kepuasan psikologikal merupakan kepuasan yang diperoleh dari atribut yang bersifat tidak berwujud dari produk. Ketika apa yang diterima oleh konsumen atas suatu pelayanan produk/ jasa berbeda dengan apa yang dipersepsikan konsumen, maka terjadi yang namanya gap (kesenjangan) kepuasan konsumen.

Oleh karena itu, seorang penjual atau organisasi bisnis tidak boleh meremehkan kualitas pelayanan yang diberikan 
kepada pelanggan. Perlu diingat bahwa kualitas pelayanan berbanding lurus dengan tingkat kepercayaan pelanggan. Kheng, dkk (2010) berpendapat bahwa pemahaman yang baik tentang hubungan antara kualitas pelayanan, kepuasaan konsumen, dan loyalitas konsumen mampu memastikan masa depan perusahaan yang lebih baik.

Menurut Gronroos (1984), ada dua macam jenis kualitas; kualitas teknik dan kualitas fungsional. Kualitas teknik berkaitan dengan apa yang pelanggan terima atas transaksi yang dilakukan, misalnya seorang kontraktor mendapatkan transportasi yang bagus dari perusahaan tempatnya bekerja, yang mengantarkannya dari seorang investor sampai kepada seorang konsumen. Kualitas fungsional tidak hanya berkaitan dengan apa yang akan didapat pelanggan tersebut, tetapi juga kualitas dari tiap proses mendapatkan produk/jasa yang diterima/ dirasakan oleh pelanggan. Seorang penjual dan pemasar seharusnya mempelajari dan memahami bagaimana cara memberikan pelayanan yang memiliki kualitas teknik dan fungsional yang dibutuhkan pelanggan.

Kualitas pelayanan dapat pula disebut kualitas produk. Kualitas suatu produk baik berupa barang maupun jasa perlu ditentukan melalui dimensi-dimensinya (Gasperz dalam Umar, 2000). Dimensi kualitas produk tersebut sebagai berikut:

I. Produk berupa barang, terdiri dari:

a. Performance, berkaitan dengan aspek fungsional suatu barang dan merupakan karakteristik utama yang memengaruhi keputusan pelanggan untuk membeli. 
b. Features, aspek performa yang menambah fungsi dasar, berkaitan dengan pilihan-pilihan produk dan pengembangannya

c. Reliability, berkaitan dengan kemampuan suatu barang dalam menjalankan fungsinya setiap kali digunakan dalam periode waktu dan kondisi tertentu. Conformance, hal ini berkaitan dengan kesesuaian terhadap spesinkasi yang telah ditetapkan sebelumnya berdasarkan keinginan pelanggan atau ketepatan antara karakteristik desain produk dengan karakteristik kualitas standar yang telah ditetapkan.

d. Durability, berkaitan dengan umur ekonomis yang berupa ukuran daya tahan atau masa pakai barang. Serviceability, karakteristik yang berkaitan dengan kecepatan, kompetensi, kemudahan, dan akurasi dalam memberikan layanan untuk perbaikan barang. Aesthetics, aSpek tentang nilai-nilai estetika yang menjadi pertimbangan pribadi dan refleksi dari preferensi individual.

e. Fit and finish, berkaitan dengan perasaan pelanggan mengenai keberadaan suatu produk sebagai produk yang berkualitas.

2. Produk berupa jasa, terdiri dari:

a. Reliability, yaitu kemampuan untuk memberikan pelayanan yang sesuai dengan $\mathrm{j}$ anji yang ditawarkan. Responsiveness, yaitu respon atau kesigapan karyawan. dalam membantu pelanggan dan memberikan pelayanan yang cepat dan tanggap.

b. Assurance, yaitu kemampuan karyawan atas pengetahuan tentang produk, kualitas keramahtamahan, perhatian dan kesopanan pelayanan, keterampilan dalam memberikan 
informasi, memberikan keamanan di dalam memanfaatkan jasa yang ditawarkan, dan kemampuan dalam menanamkan kepercayaan pelanggan terhadap perusahaan.

c. Emphaty, merupakan gabungan dari dimensi akses (kemudahan mendapatkan jasa), komunikasi (komunikasi dua arah antara pelanggan dan penjual), dan pemahaman pelanggan (usaha perusahaan untuk mengetahui dan memahami kebutuhan dan keinginan pelanggan).

d. Tangible, yaitu penampilan fasilitas fisik, seperti gedung dan ruangan kantor. 


\section{BAB IV}

\section{Gambaran Umum Perbankan Syariah}

\section{A. Pengertian Bank Syariah}

Bank secara bahasa diambil dari bahasa Itali, yakni banco yang mempunyai arti meja. Penggunaan istilah ini disebabkan dalam realita kesehariannya bahwa setiap proses dan transaksi sejak dahulu dan mungkin di masa yang datang dilaksanakan di atas meja. Dalam bahasa arab, bank biasa disebut dengan mashrof yang berarti tempat berlangsung saling menukar harta, baik dengan cara mengambil ataupun menyimpan atau selain untuk melakukan muamalat.

Menurut UU Republik Indonesia No. 10 Tahun 1998, tentang perubahan atas UU No. 7 Tahun 1992 tentang perbankan bahwa Bank umum adalah bank yang melaksanakan kegiatan usaha secara konvensional dan berdasarkan prinsip syariah yang dalam kegiatannya memberikan jasa dalam lalu lintas pembayaran. Sedang pengertian prinsip syariah itu sendiri adalah aturan berdasarkan hukum Islam.

Menurut Karnaen Purwaatmadja, bank syariah adalah bank yang beroperasi sesuai dengan prinsipprinsip Islam, yakni bank dengan tata cara dan operasinya mengikuti ketentuan-ketentuan syariah Islam. Salah satu unsur yang harus dijauhi dalam muamalah Islam adalah 
praktik-praktik yang mengandung unsur riba (spekulasi dan tipuan).

Pada umumnya, hal yang dimaksud dengan bank syariah adalah lembaga keuangan yang usaha pokoknya memberi layanan pembiayaan kredit dan jasa dalam lalu lintas pembayaran serta peredaran uang yang beroperasi disesuaikan dengan prinsip-prinsip syariah. Bank syariah merupakan bank yang beroperasi sesuai dengan prinsip syariah Islam, mengacu kepada ketentuan-ketentuan yang ada dalam Al-Quran dan Al-Hadis. Dengan mengacu kepada Al-Quran dan Al-Hadist, maka bank syariah diharapkan dapat menghindari kegiatan-kegiatan yang mengandung unsur riba dan segala hal yang bertentangan dengan syariat Islam.

Adapun perbedaan pokok antara bank syariah dengan bank konvensioanl terdiri dari beberapa hal. Bank syariah tidak melaksanakan sistem bunga dalam seluruh aktivitasnya, sedang bank konvensional memakai sistem bunga. Hal ini memiliki implikasi yang sangat dalam dan sangat berpengaruh pada aspek operasional dan produk yang dikembangkan oleh bank syariah. Bank syariah lebih menekankan sistem kerja serta partnership, kebersamaan terutama kesiapan semua pihak untuk berbagi termasuk dalam hal-hal keuntungan dan kerugian. 


\section{B. Peranan Bank Syariah Bagi Perekonomian}

Perbankan merupakan sebagai salah satu lembaga keuangan yang berfungsi sebagai lembaga intermediasi, yaitu sebagai penghimpun dana dari masyarakat yang mempunyai kelebihan dana dan menyalurkan kembali kepada masyarakat yang membutuhkan dana dalam bentuk pembiayaan.

Eksistensi perbankan syariah di Indonesia mulai mengalami perkembang pada era reformasi setelah dikeluarkannya Undang-Undang Nomor 10 Tahun 1998 yang menerangkan bahwa bank konvensional diperbolehkan untuk memperluas jangkauannya dengan membuka cabang syariah, atau mengkonversi menjadi bank syariah secara keseluruhan. Dalam Undang-Undang Nomor 10 Tahun 1998 juga diatur mengenai landasan hukum, jenis usaha yang bisa diimplementasikan dan dioperasikan oleh bank syariah

Jika dibedakan berdasarkan jenisnya, bank syariah terdiri dari Bank Umum Syariah dan Bank Pembiayaan Rakyat Syariah. Bank syariah melakukan kegiatan usahanya dengan penyaluran pembiayaan seperti: pembiayaan konsumtif, investasi dan modal kerja.

Bank syariah adalah bank yang menjalankan fungsi intermediasinya berdasarkan prinsip-prinsip syariat Islam. Peran dan fungsi bank syariah, di antaranya sebagai berikut:

a. Sebagai tempat menghimpun dana dari masyarakat atau dunia usaha dalam bentuk tabungan 
(mudharabah), dan giro (wadiah), serta menyalurkannya kepada sektor rill yang membutuhkan.

b. Sebagai tempat investasi bagi dunia usaha (baik dana modal maupun dana rekening investasi) dengan menggunakan alat-alat investasi yang sesuai dengan syariah.

c. Menawarkan berbagai jasa keuangan berdasarkan upah dalam sebuah kontrak perwakilan atau penyewaan.

d. Memberikan jasa sosial seperti pinjaman kebajikan, zakat dan dana sosial lainnya yang sesuai dengan ajaran Islam.

\section{Landasan Hukum Bank Syariah}

1) Landasan Hukum Islam

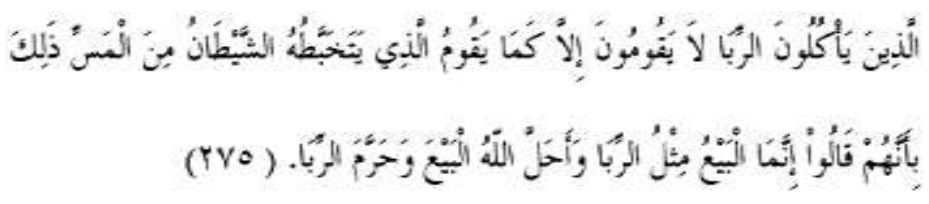

Artinya:

Orang-orang yang makan (mengambil) riba tidak dapat berdiri melainkan seperti berdirinya orang yang kemasukan syaitan lantaran (tekanan) penyakit gila. Keadaan mereka yang demikian itu, adalah disebabkan mereka berkata (berpendapat), sesungguhnya jual-beli 
itu sama dengan riba, padahal Allah telah menghalalkan jual-beli dan mengharamkan riba. (QS. Al-Baqarah : 275).

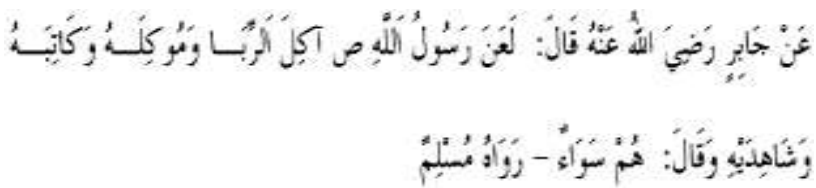

Artinya:

Dari Jaabir ra bahwa Rasulullah SAW melaknat pemakan riba', yang memberi makan, kedua orang saksinya dan pencatatnya. (HR Muslim).

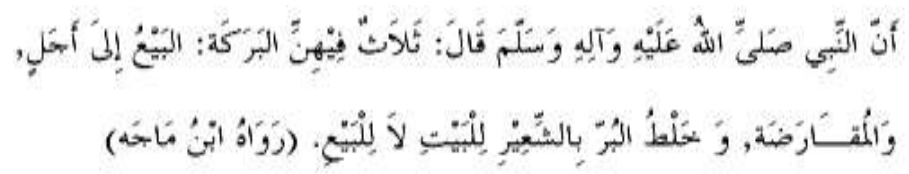

"Tiga perkara yang didalamnya terdapat keberkahan: menjual dengan pembayaran secara tangguh, muqaradhah (nama lain dari mudharabah), dan mencampur gandum dengan tepung untuk keperluan rumah dan tidak untuk dijual" (HR. Ibnu Majah).

2) Peraturan Bank Indonesia mengenai Perbankan syariah 
1) $\mathrm{PBI}$ No.9/19/PBI/2007 tentang pelaksanaan prinsip dalam kegiatan penghimpunan dan penyaluran dana serta pelayanan jasa bank syariah.

2) $\mathrm{PBI}$ No.7/35/PBI/2005 tentang perubahan atas peraturan bank Indonesia No. 6/24/PBI/2004 tentang bank umum yang melaksanakan kegiatan usaha berdasarkan prinsip syariah.

3) $\mathrm{PBI} N$ No.6/24/PBI/2004 tentang bank umum yang melaksnakan kegiatan usaha berdasarkan prinsip syariah

3) Produk Penyaluran Dana

Dalam menyalurkan dananya pada nasabah, produk pembiayaan syariah terbagi ke dalam empat kategori yaitu:

a) Prinsip Jual Beli (Bay')

Prinsip jual beli dilaksanakan sehubungan dengan adanya perpindahan kepemilikan barang atau benda (transfer of property). Prinsip ini dapat dibagi sebagai berikut:

(1) Pembiayaan Murabahah

Menurut Ibnu Rusyd pengertian murabahah yaitu: Bahwa pada dasarnya murabahah tersebut 
adalah jual beli dengan kesepakatan pemberian keuntungan bagi penjual dengan memperhatikan dan memperhitungkannya dari modal awal si penjual.

(2) Pembiayaan Salam

Salam adalah transaksi jual beli di mana barang yang diperjualbelikan belum ada.

(3) Pembiayaan Istisna

Produk Istisna menyerupai produk salam, tapi dalam Istisna pembayarannya dapat dilakukan oleh bank dalam beberapa kali (termin) pembayaran. Istisna dalam Bank Syariah umumnya diaplikasikan pada pembiayaan manufaktur dan kontruksi.

(4) Prinsip Sewa (ljarah)

Transaksi ljarah dilandasi adanya perpindahan manfaat. Jadi pada dasarnya prinsip ljarah sama saja dengan prinsip jual beli. Namun perbedaanya terletak pada objek traksaksinya. Bila pada jual beli objek transaksinya adalah barang, maka pada ljarah objek transaksinya adalah jasa.

(5) Pembiayaan Musharakah 
Bentuk umum dari usaha bagi hasil adalah Musharakah (shirkah atau sharikah atau serikat atau kongsi). Dalam artian semua modal disatukan untuk dijadikan modal proyek Musharakah dan dikelola bersama-sama.

(6) Pembiayaan Mudharabah

Mudharabah adalah bentuk kerjasama antara dua atau lebih pihak dimana pemilik modal (shahibul maal) mempercayakan sejumlah modal kepada pengelola (mudarib) dengan suatu perjanjian pembagian keuntungan.

4) Akad Pelengkap

a) Hiwalah (Alih Utang-Piutang)

Tujuan fasilitas Hiwalah adalah untuk membantu supplier mendapatkan modal tunai agar dapat melanjutkan produksinya.

b) Rahn (Gadai)

Tujuan akad rahn adalah untuk memberikan jaminan pembayaran kembali kepada bank dalam memberikan pembiayaan.

c) Qard (Pinjaman Uang) 
Qard adalah pinjaman uang. Aplikasi qard dalam perbankan biasanya dalam empat hal, yaitu: pertama, sebagai pinjaman talangan haji, kedua, sebagai pinjaman tunai (cash advanced), ketiga, sebagai pinjaman kepada pengusaha kecil, keempat, sebagai pinjaman kepada pengurus bank.

d) Wakalah (Perwakilan)

Wakalah dalam aplikasi perbankan terjadi apabila nasabah memberikan kuasa kepada bank untuk mewakili dirinya melakukan pekerjaan jasa tertentu, seperti inkasi dan transfer uang.

e) Kafalah (Garansi Bank)

Garansi bank dapat diberikan dengan tujuan untuk menjamin pembayaran suatu kewajiban pembayaran.

5) Produk Penghimpunan Dana

Prinsip operasional syariah yang diterapkan dalam penghimpunan dana masyarakat adalah prinsip Wadiah dan Mudharabah.

6) Produk Jasa

a) Sharf (Jual Beli Valuta Asing) 
Jual beli mata uang yang tidak sejenis ini, penyerahannya harus dilakukan pada waktu yang sama (spot).

b) Ijarah (Sewa)

Menurut bahasa ijarah adalah (menjual mafaat). Sedangkan menurut istilah syarak menurut pendapat ulama Hanafiyah: ljarah adalah akad atas suatu kemanfaatan dengan pengganti. 


\section{Daftar Pustaka}

Abazhah, Nizar. Syahsiyah Al-Rasul. Jakarta:Zaman.2013

Abdullah. Asuransi Syariah, Jakarta: PT. Elex Media Komputindo,2006

Abdullah, Thamrin dan Tantri, Manajemen Pemasaran. Jakarta: Rajawali Press, 2014

Al Arif, M. Nur Rianto, Dasar-DasarPemasaran Bank Syariah. Bandung:Alfabeta, 2010.

Askari. Hossein dkk, Globalization And Islamic Finance: Convergence, Prospect and Challenges, John Wiley \& Son (Asia) Pte., Ltd., Singapore, 2010

Case. Karl E dan Fair. Ray C, Prinsip-Prinsip Ekonomi, Edisi Kedelapan, Jilid 1, Penerbit Erlangga, Jakarta 2002

Huda. Nurul dkk, Pemasaran Syariah: Teori dan Aplikasi, Edisi pertama, Kencana, Depok, 2017.

Kasmir, Pemasaran Bank, Jakarta: Kencana,2008.

Kotler. Philip dkk, Marketing Management, Ninth Edition, Prentice all Publishing, 1997.

Kotler. Philip dkk, Marketing Management: An Asian Perspective, Fourth Edition, Prentice Hall Pearson Education South Asia Pte., Ltd., Singapore, 2006. 
Malahayati, Rahasia SuksesBisnis Rasululloh, Yogyakarta: Great Publisher, 2010.

Mardani, Fiqh Ekonomi Syariah: Fiqh Muamalah, Jakarta: Kencana, 2010.

Santosa, Ippho \& Tim Khalifah, Muhammad Sebagai Pedagang, Jakarta: Kompas Gramedia, 2014.

Tarmizi, Erwandi. Harta Haram Muamalat Kontemporer, Edisi Kedelapanbelas, Bogor: Berkat Mulia Insani, 2018

Toutounchian. Iraj, Islamic Money and Banking: Integrating Money in Capital Theory, John Wiley \& Son (Asia) Pte., Ltd., Singapore, 2009

Wahbah, Zuhaili, Al-Fiqhu Al-Islami wa Adilatuhu Juz V, Daar Alfkr, 1984. 


\section{BIODATA PENULIS}

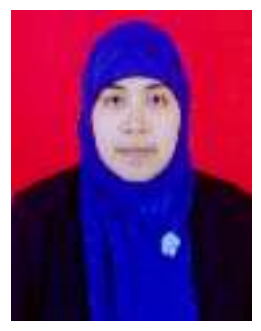

Fitri Nur Latifah, S.E., M.E.Sy., lahir di Sidoarjo 11 September 1978. Kepala Program Studi Perbankan Syariah Fakultas Agama Islam Universitas Muhammadiyah Sidoarjo ini pernah mengenyam pendidikan di beberapa Universitas. Gelar Ahli Madya diperoleh pada Politeknik Perkapalan Negeri ITS Surabaya dengan jurusan Power Electrical Engineering, kemudian gelar kesarjanaan (Sarjana Ekonomi) dari jurusan Manajemen STIE Dwipawacana Jakarta dan gelar Magister Ekonomi Syariah dari Universitas Islam Azzahra Jakarta. Penulis sebelumnya konsultan untuk beberapa kementerian antara lain Kementerian Perdagangan RI, Kementerian Tenaga Kerja dan Transmigrasi RI, Kementerian Pembangunan Daerah Tertinggal RI, Kementerian Pemuda dan Olah Raga RI dll. Buku yang pernah di terbitkan Buku Ajar Aplikasi Komputer (2017).

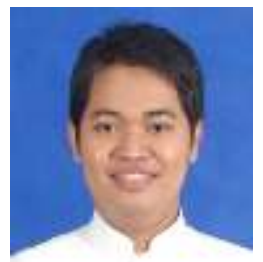

M. Ruslianor Maika. lahir di Kumai, 27 Maret 1984. Lulus Sarjana Kehutanan dari Universitas Winaya Mukti, Bandung tahun 2008. Penulis melanjutkan studi S2 program Master Business Administration Program Pascasarjana Institut Teknologi Bandung pada tahun 2012. Penulis sebelumnya bekerja di Bank Muamalat Indonesia sebagai Service Assistance of Corporate Branch dan memulai karir sebagai dosen di Universitas Muhammadiyah Sidoarjo pada tahun 2015. Buku yang pernah di terbitkan Ekonomi Islam: Teori dan Aplikasi (2017), Buku Ajar Aplikasi Komputer (2017). 